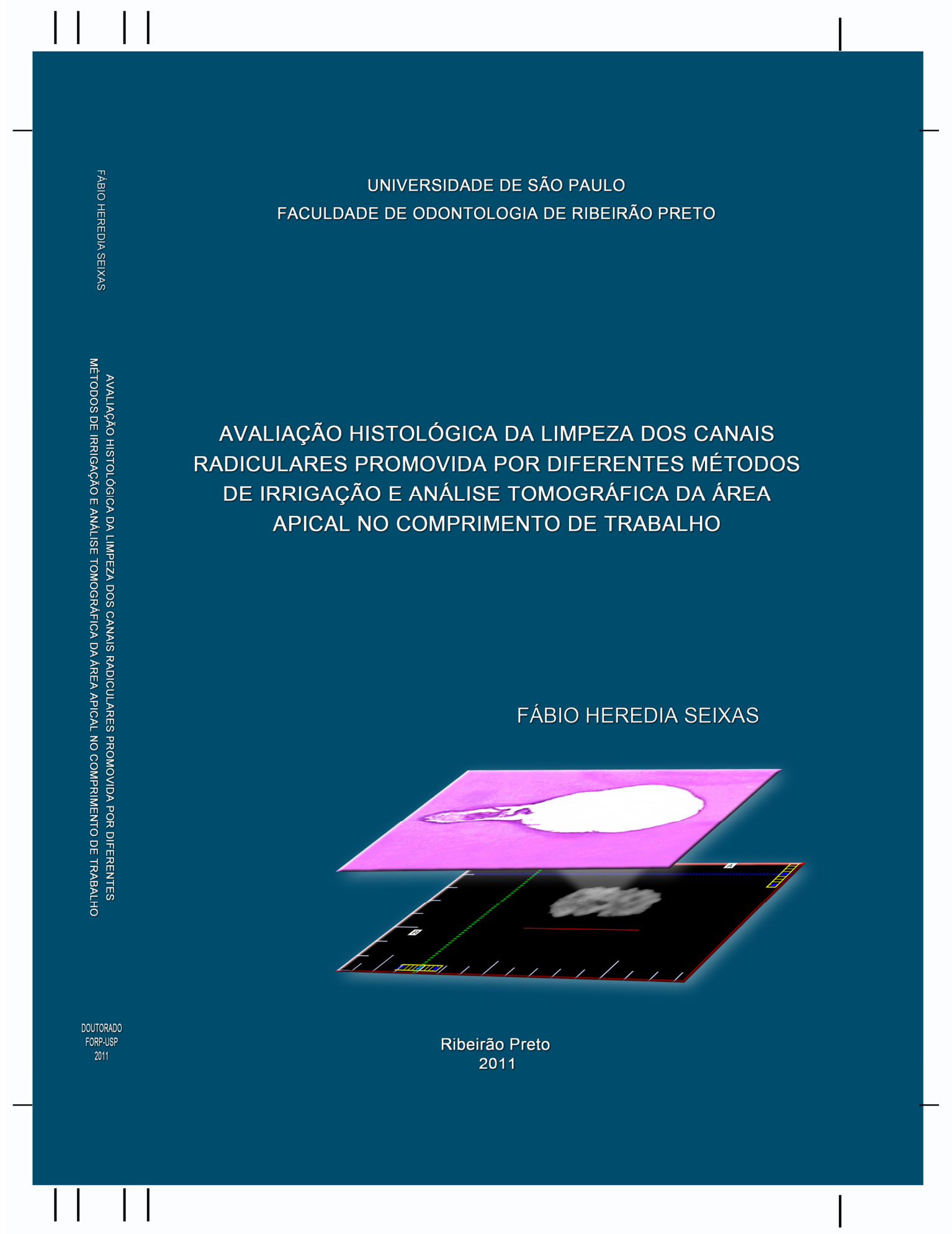


UNIVERSIDADE DE SÃO PAULO

FACULDADE DE ODONTOLOGIA DE RIBEIRÃO PRETO

\begin{abstract}
AVALIAÇÃO HISTOLÓGICA DA LIMPEZA DOS CANAIS RADICULARES PROMOVIDA POR DIFERENTES MÉTODOS DE IRRIGAÇÃO E ANÁLISE TOMOGRÁFICA DA ÁREA APICAL NO COMPRIMENTO DE TRABALHO
\end{abstract}

Fábio Heredia Seixas

Orientador: Prof. Dr. Jesus Djalma Pécora

Ribeirão Preto 2011 


\section{AVALIAÇÃO HISTOLÓGICA DA LIMPEZA DOS CANAIS RADICULARES PROMOVIDA POR DIFERENTES MÉTODOS DE IRRIGAÇÃO E ANÁLISE TOMOGRÁFICA DA ÁREA APICAL NO COMPRIMENTO DE TRABALHO}

Tese apresentada à Faculdade de Odontologia de Ribeirão Preto da Universidade de São Paulo, para obtenção do título de Doutor em Odontologia.

Área de Concentração: Odontologia Restauradora, opção Endodontia.

Orientador: Prof. Dr. Jesus Djalma Pécora

Ribeirão Preto 
Autorizo a reprodução e divulgação total ou parcial da presente obra, por qualquer meio convencional ou eletrônico, para fins de estudo e pesquisa, desde que citada à fonte.

Ficha catalográfica preparada pela Seção de tratamento da informação do Serviço da Biblioteca - EEC-USP

Seixas, Fábio Heredia

Avaliação histológica da limpeza dos canais radiculares promovida por diferentes métodos de irrigação e análise tomográfica da área apical no comprimento de trabalho. Ribeirão Preto, 2011.

191 p. : il. ; $30 \mathrm{~cm}$.

Tese de Doutorado, apresentada à Faculdade de Odontologia de Ribeirão Preto da Universidade de São Paulo (FORP-USP). Área de Concentração: Odontologia Restauradora, Opção: Endodontia.

Orientador: Pécora, Jesus Djalma

1. Endodontia. 2. Limpeza dos canais radiculares. 3.Instrumentação rotatória. 4. Tomografia Computadorizada cone beam. 5. Diâmetro anatômico. 
SEIXAS, Fábio Heredia.

Avaliação histológica da limpeza dos canais radiculares promovida por diferentes métodos de irrigação e análise tomográfica da área apical no comprimento de trabalho.

Tese apresentada à Faculdade de Odontologia de Ribeirão Preto da Universidade de São Paulo, para obtenção do título de Doutor em Odontologia.

Área de Concentração: Odontologia Restauradora, opção Endodontia.

Aprovado em:

Banca Examinadora

Prof. Dr.

Instituição:

Julgamento:

Assinatura:

Prof. Dr.

Instituição:

Julgamento:

Assinatura:

Prof. Dr.

Instituição:

Julgamento:

Assinatura:

Prof. Dr.

Instituição:

Julgamento:

Assinatura:

Prof. Dr.

Instituição:

Julgamento: Assinatura: 

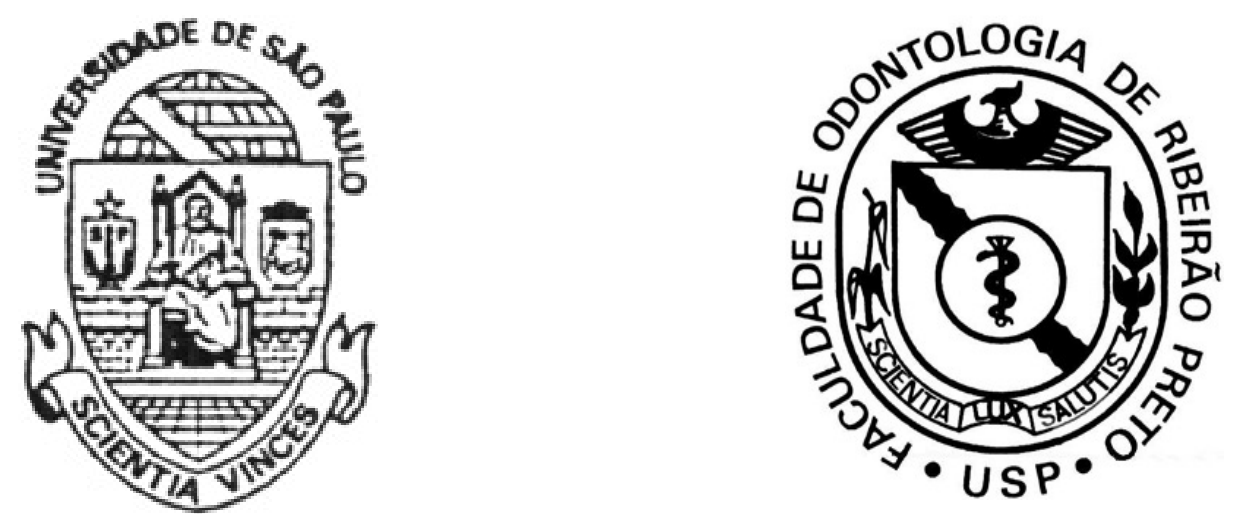

Este trabalho foi realizado no Laboratório de Pesquisa em Endodontia do Departamento de Odontologia Restauradora da Faculdade de Odontologia de Ribeirão Preto da Universidade de São Paulo e no Serviço de Patologia da Universidade de Ribeirão Preto, com apoio financeiro CNPq (bolsa doutorado). 
“Aprender é a única coisa de que a mente

nunca se cansa, nunca tem medo e nunca se arrepende."

Leonardo da Vinci 

Dedicatória 

Aos meus filhos Isabela e Rafael por me tornarem uma pessoa melhor a cada dia. AMO VOCÊS! 

Agradecimentos 

A DEUS, Grande Arquiteto do Universo pela oportunidade da Vida, por me iluminar e me prover de forças para vencer os obstáculos necessários para o crescimento. 

Aos meus pais Marisa e Luís Filipe pela oportunidade de realização pessoal e profissional.

A meus avós Romualdo e Elza (in memoriam) e Rubens e Carolina, pelos valores éticos transmitidos. 

À minha querida esposa e companheira Letícia, por estar sempre ao meu lado, incentivando e aceitando minhas escolhas, dando suporte nos meus inúmeros momentos de ausência, imprescindíveis para a realização deste trabalho. TE AMO! 

Ao Prof. Dr. Jesus Djalma Pécora, pela orientação, sugestões e criticas que muito contribuíram para o desenvolvimento deste trabalho. Obrigado por todas as oportunidades a mim confiadas 

Ao CNPq, Conselho Nacional de Desenvolvimento Científico e Tecnológico, pela concessão da bolsa de estudos.

A Faculdade de Odontologia de Ribeirão Preto da Universidade de São Paulo pelas facilidades concedidas.

Ao Prof. Dr. Danyel Elias da Cruz Perez, pela colaboração na confecção do material histológico.

A senhora Marilena Heredia, pela dedicação e eficiência na preparação do material histológico.

A Profa. Dr. Yara T. Correa Silva Sousa, coordenadora do curso de Odontologia da Universidade de Ribeirão Preto (UNAERP), por permitir a utilização do Laboratório de Patologia para a confecção do material histológico.

Ao Prof. Mike dos Reis Bueno do Centro de Diagnóstico Bucal e Maxilofacial de Cuiabá (CROIF), pelo valioso auxilio na obtenção das imagens na fase tomográfica inicial, deste estudo.

Aos professores José Antônio Brufatto Ferraz, Danilo A. de Oliveira e Luís Fernando Jardim da O3D - Odontologia Diagnóstica de Ribeirão Preto, pela inestimável ajuda na aquisição das imagens na fase tomográfica final.

Ao amigo Prof. Dr. Danilo Mathias Zanello Guerisoli, da Universidade Federal de Campo Grande, pelas valiosas sugestões e colaboração na análise estatística.

Aos Professores Doutores Manoel Damião de Souza Neto, Antônio Miranda da Cruz Filho, Paulo Cesar Saquy, Luis Pascoal Vansan, Ricardo Gariba Silva, Isabel Fröner, Wanderley Ferreira da Costa e Débora Fernandes Costa Guedes, do curso de Pós-Graduação do Departamento de Odontologia Restauradora da Faculdade de Odontologia da Universidade de São Paulo pela transmissão do conhecimento. 

Ao Reginaldo Santana da Silva, técnico do laboratório de Pesquisa em Endodontia da FORP/USP, pela amizade e constante disponibilidade em ajudar.

Ao Dr. Eduardo Gdakian da Lochus, pela doação dos instrumentos rotatórios de NiTi.

Ao Dr. Ulisses Campregher da Durr Dental (Alemanha), pelo empréstimo do aparelho de irrigação hidrodinâmico.

Ao Sr. Kléber G. Motta da Odontoline (Kavo, Brasil), pelo empréstimo do adaptador de engate rápido para micro motor necessário para o acoplamento do aparelho de irrigação.

As senhoras Ivanete Batista da Silva Gomes e Fátima Nassif Facchini, secretárias, respectivamente, do Centro de Diagnóstico Bucal e Maxilofacial de Cuiabá (CROIF) e da O3D - Odontologia Diagnóstica de Ribeirão Preto pela atenção durante o período das tomadas tomográficas.

Aos colegas da segunda turma de Pós-Graduação Cid Alonso Manicardi, Homero Cassonato Júnior, Renato Jonas dos Santos Schiavoni, Rodrigo Ribeiro Gonçalves pelos ideais e caminhos que juntos percorremos e vencemos.

Aos demais colegas que direta ou indiretamente me incentivaram e colaboraram para a realização deste trabalho.

Às funcionárias do Departamento de Odontologia Restauradora: Maria Amália Viesti de Oliveira Motta, Luiza Godoi Pitol, Carlos Feitosa dos Santos, Maria Isabel C.F. Miguel e Rosângela Angelini, pelo carinho e atenção no dia-a-dia.

Às secretárias da Pós-graduação Isabel Cristina G. Sola e Regiane C.M. Saciolotto, pela disponibilidade e constante ajuda.

Ao Alberto Parahyba Quartim de Moraes pela revisão do texto.

A Gabriel Valente da Biblioteca Central da USP-RP pela revisão das normas e referências.

A todos os meus familiares e amigos pelo incessante apoio e estímulo. 


\section{RESUMO}

SEIXAS, F.H. Avaliação histológica da limpeza dos canais radiculares promovida por diferentes métodos de irrigação e análise tomográfica da área apical no comprimento de trabalho. 2011. 191p. Tese (Doutorado) - Faculdade de Odontologia de Ribeirão Preto, Universidade de São Paulo, Ribeirão Preto, 2011.

O objetivo deste estudo foi avaliar in vitro a limpeza das paredes dos canais radiculares pelo método histológico e a determinação tomográfica da área apical antes e após a instrumentação de dentes portadores de achatamento mésio-distal, submetidos a diferentes sistemas de irrigação e preparados pela técnica rotatória mecanizada com instrumentos de níquel-titânio. Para tanto, foram utilizados 42 dentes incisivos inferiores humanos uniradiculares de estoque que tiveram suas áreas anatômicas apicais escaneados pelo tomógrafo computadorizado ICAT cone beam e analisados por meio do software I-CATvision ${ }^{\circledR}$. Posteriormente a realização da cirurgia de acesso e preparo cervical, foi determinado o instrumento apical inicial e comprimento de trabalho dos dentes pelo método clínico. Cada espécime foi instrumentado mecanicamente pela técnica Free Tip Preparation até três, quatro e cinco instrumentos acima do inicial, de acordo com o grupo experimental. A irrigação foi feita pelos métodos convencional e hidrodinâmico, com hipoclorito de sódio a 2,5\% entre cada troca de instrumento e irrigação final com solução de EDTA a 17\%. A seguir, os dentes foram submetidos à nova tomada tomográfica para a visualização do diâmetro cirúrgico. As mensurações obtidas clinicamente e por meio do tomógrafo revelaram não haver diferenças significantes entre os diâmetros anatômicos através dos dois métodos ( $p>0,05)$, porém observaram-se diferenças entre os diâmetros cirúrgicos $(\mathrm{p}<0,001)$. Posteriormente, as amostras foram submetidas ao processo histológico com coloração H.E. e seus terços apicais analisados por microscópio óptico com aumento de 40X. As imagens foram capturadas digitalmente pelo software Movie Maker ${ }^{\circledR}$ e os resultados da limpeza foram submetidos à análise estatística (two-way ANOVA com pós-teste de Bonferroni). Os resultados não demonstraram diferença entre os tipos de irrigação testados $(\mathrm{p}=0,78)$, mas, revelou haver diferenças entre os grupos no que tange à limpeza dos canais radiculares dos diferentes diâmetros apicais de instrumentação $(\mathrm{p}<0,001)$. O preparo biomecânico com quatro instrumentos acima do instrumento apical inicial determinou uma área de atuação significantemente superior ao mesmo preparo com apenas três instrumentos, produzindo paredes dentinárias mais limpas. O preparo com cinco instrumentos acima do instrumento apical inicial, entretanto, não foi capaz de melhorar a limpeza do terço apical quando comparado ao preparo produzido por quatro limas além do instrumento apical inicial ( $>0,05)$. Foram observados predominância do formato elíptico das paredes dos canais radiculares no comprimento de trabalho das amostras estudadas.

Palavras-chave: Endodontia, Limpeza dos canais radiculares, instrumentação rotatória, tomografia computadorizada cone beam, diâmetro anatômico. 


\begin{abstract}
SEIXAS, F.H. Histologic evaluation of root canal cleaning promoted by different irrigation methods and tomographic analysis of the apical area in the working length. 2011. 191p. Thesis (Ph.D.) - School of Dentistry of Ribeirão Preto, University of São Paulo, Ribeirão Preto, 2011.
\end{abstract}

The aim of this study was to evaluate in vitro the cleanliness of root canal walls and the precision of tomographic analysis to determine the apical area before and after instrumentation of teeth with mesio-distal flattening, submitted to different irrigations systems and prepared by rotary nickel-titanium instruments. Forty-two human, single-canal lower incisors had their apical area evaluated either clinically or by tomography. Each specimen was instrumented using the Free Tip Preparation technique up to three, four or five instruments above the initial, according to the experimental group. Irrigation was performed by conventional or hydrodynamic means, using 2,5\% sodium hypochlorite after each instrument and a final flush of $17 \%$ EDTA. The samples were submitted to a new tomographic scan and prepared for observation under a light microscope. Images were digitally obtained, analyzed and the results were submitted to statistical analysis (two-way ANOVA complemented by Bonferroni's posttest). The readings made clinically or by the tomography revealed no differences between the anatomical diameters $(p>0.05)$, but the surgical were different $(\mathrm{p}<0.001)$. There were no differences between irrigation methods $(\mathrm{p}=0.78)$. The results regarding the action of the instrument on the root canal walls showed that irrigation did not present a significant impact on the action of the instrument in the canal $(\mathrm{p}=0,11)$; however, the statistical analysis revealed differences between instrumentation techniques $(p<0.001)$. Instrumentation with four instruments above the initial file determined a significant increase in the actuation area when compared to preparation with three instruments. Preparation with five files above the initial did not result in an improved cleanliness $(p>0,05)$. It can be concluded that the tomography shows discrepancies when compared to clinical determination of the anatomical diameter. Regarding the cleanliness obtained by the different irrigation methods, no differences were observed between groups. Preparation with four instruments showed a significant superior acting area when compared to only three instruments above the initial file. The same could not be observed when five instruments were used.

Keywords: Endodontic. Root canal cleaning. Rotary instrumentation. Cone beam Computed Tomography. Anatomic diameter. 



\section{LISTA DE TABELAS}

Tabela I. Dados em milímetros quadrados das áreas apicais das regiões correspondentes ao comprimento de trabalho das amostras (Tomógrafo Computadorizado)

Tabela II. Dados em milímetros quadrados das áreas apicais das regiões correspondentes ao comprimento de trabalho das amostras (Clínico)

Tabela III. Estatística descritiva e teste de normalidade de D'Agostino e Pearson

Tabela IV. Análise de variância com dois fatores de variação para dados vinculados e teste complementar de Bonferroni aplicados aos resultados da medida da área da região do comprimento de trabalho-

Tabela V. Valores da área livres de débris após o preparo dos canais radiculares (em porcentagem)

Tabela VI. Estatística descritiva e teste de normalidade de D'Agostino e Pearson. Transformação quadrática dos dados originais-

Tabela VII. Estatística descritiva e teste de normalidade de D'Agostino e Pearson. Transformação quadrática dos dados originais

Tabela VIII. Análise de variância com dois fatores de variação aplicada transformação quadrática dos resultados originais das áreas isentas de débris após o preparo dos canais radiculares 

Tabela IX. Porcentagem da dentina radicular da secção transversal apical onde houve atuação do instrumento (Valores originais)

Tabela X. Estatística descritiva e teste de normalidade de D'Agostino e Pearson. Transformação quadrática dos dados originais-----------------

Tabela XI. Análise de variância com dois fatores de variação e teste complementar de Bonferroni aplicados à porcentagem da dentina radicular da secção transversal apical onde houve atuação do instrumento. Transformação quadrática dos dados originais

Tabela XII. Análise da geometria apical dos canais radiculares (CT) por meio de tomografia computadorizada $(\%)$

Tabela XIII. Análise da geometria apical dos canais radiculares (CT) por meio histológico e tomográfico $(\%)$ 



\section{LISTA DE FIGURAS}

Figura 1. Bandeja de aço inox contendo silicona de condensação em seu interior--- 102

Figura 2. Disposição dos dentes inseridos na matriz de silicona--------------------- 102

Figura 3. Disposição dos dentes na placa de acrílico---------------------------------- 103

Figura 4. Placa de acrílico contendo 21 dentes e as cinco perfurações de orientação-

Figura 5. Tomógrafo Computadorizado I-CAT's Cone Beam 3-D 104

Figura 6. Esquema com a sequência dos dentes nos grupos (leitura no tomógrafo)-105

Figura 7. Detalhe da mesa própria para pesquisa adaptada na haste do Tomógrafo-106

Figura 8. Brocas LA Axxess ${ }^{\circledR}$ (SybronEndo, USA) 20/.06 e 35/.06

Figura 9. Fluxograma do esquema de divisão de dentes em um grupo para o exame tomográfico

Figura 10. Instrumentos RT-Files ${ }^{\circledR}$ (Densell, Suécia) e Quantec series ${ }^{\circledR}$ (SybronEndo, USA) utilizados no preparo dos dentes-

Figura 11. Motor elétrico EndoEst ${ }^{\circledR}\left(\right.$ Geosoft $^{\circledR}$, Rússia) utilizado no preparo dos canais radiculares

Figura 12. Seringa luer lock utilizada na irrigação convencional dos canais radiculares (a). Detalhe da ponta da agulha de irrigação Endo-Eze Irrigator Tips $^{\circledR}$ com abertura lateral (b)

Figura 13. Aparelho de irrigação RinsEndo ${ }^{\circledR}$ (Dürr Dental, Alemanha) utilizado na irrigação hidrodinâmica dos canais radiculares (a). Detalhe da ponta da agulha de irrigação do sistema RinsEndo ${ }^{\circledR}$ com abertura lateral (b)

Figura 14. Tela fornecida pelo programa para visualização e análise das imagens tomográficas 
Figura 15. Esquema das imagens tomográficas inicial (área anatômica) em (a) e final (área cirúrgica) em (b) dos espécimes no CT

Figura 16. Micrótomo Leica $R M 2145^{\circledR}$ (Leica Instruments GmbH, Nussloch, Germany)

Figura 17. Banho histológico (ANCAP, São Paulo, Brasil)

Figura 18. Fotomicrografia da região apical com 40 vezes de aumento (a), e (b) imagem da região avaliada dividindo a área total (linha preta) e a área com débris (linha vermelha)

Figura 19. Fotomicrografia da região apical com $40 \mathrm{X}$ de aumento (a), e (b) imagem da mesma região com as demarcações das áreas onde não houve contato do instrumento (linha preta) e onde o instrumento tocou nas paredes dos canais radiculares (linha vermelha)

Figura 20. Organograma com o esquema do experimento-

Figura 21. Valores da média e o desvio-padrão dos resultados obtidos para a determinação das áreas apicais anatômicas e cirúrgicas das amostras------

Figura 22. Valores da área livre de débris após o preparo dos canais radiculares com diferentes métodos de irrigação e técnicas de instrumentação dos canais radiculares

Figura 23. Valores obtidos para a porcentagem de dentina radicular da região apical onde houve atuação do instrumento

Figura 24. Porcentagem da geometria visualizada nos canais radiculares na região apical (CT) por meio da tomografia computadorizada inicial (anatômica) e final (cirúrgica) 
Figura 25. Porcentagem da geometria visualizada nos canais radiculares na região apical (CT) por meio histológico e tomográfico após preparo dos canais radiculares

Figura 26. Topogramas da região apical no comprimento de trabalho dos espécimes obtidos por meio da tomografia computadorizada cone beam. Área anatômica do elemento 1 (a) e área cirúrgica do mesmo elemento (b)-----

Figura 27. Topogramas da região apical no comprimento de trabalho dos espécimes obtidos por meio da tomografia computadorizada cone beam. Área anatômica do elemento 3 (a) e área cirúrgica do mesmo elemento (b)-----

Figura 28. Fotomicrografias da região apical dos espécimes do grupo I, com aumento de 40X. Em (a), canal radicular apresentando áreas (setas) em que o instrumento não tocou nas paredes (três instrumentos acima do IAI) e ausência de débris; (b), canal achatado preparado com três instrumentos acima do IAI apresentando débris na luz de seu canal, onde o instrumento não foi efetivo (seta preta), e área onde o instrumento tocou nas paredes (seta branca); (c), região não instrumentada apresentando débris (seta) em um canal acentuadamente achatado preparado com quatro instrumentos acima do IAI; (d), paredes instrumentadas (seta preta) e não preparadas (seta branca), canal preparado com cinco instrumentos acima do IAI e ausência de débris-----

Figura 29. Fotomicrografias da região apical dos espécimes do grupo II, com aumento de 40X. Em (a), canal radicular apresentando achatamento acentuado de raiz com área (seta) em que o instrumento não tocou na parede (três instrumentos acima do IAI) com presença de débris; (b), canal radicular instrumentado com quatro instrumentos acima do IAI 
apresentando débris na região onde o instrumento não foi efetivo (setas); (c), canal radicular instrumentado por três instrumentos acima do IAI apresentando grande quantidade de débris na luz de seu canal (seta preta) e região onde o instrumento tocou nas paredes (seta branca); (d), canal radicular preparado com cinco instrumentos acima do IAI demonstrando ausência de débris e paredes preparadas praticamente em sua totalidade---

Figura 30. Fotomicrografias da região apical do espécime número 06 do grupo I, com aumento de 40X em (a), canal radicular apresentando achatamento de raiz com área (seta) em que o instrumento não tocou na parede (cinco instrumentos acima do IAI); (b), aumento de 100X apresentando mais detalhes da área não tocada pelo instrumento; (c), aumento de 400X, detalhes do limite entre a área instrumentada (seta preta) e a não tocada pelo instrumento (seta branca) e, (d), aumento de 1000X, presença de débris (seta preta) e camada de pré-dentina (seta branca) na área em que o instrumento não tocou- 



\section{SUMÁRIO}

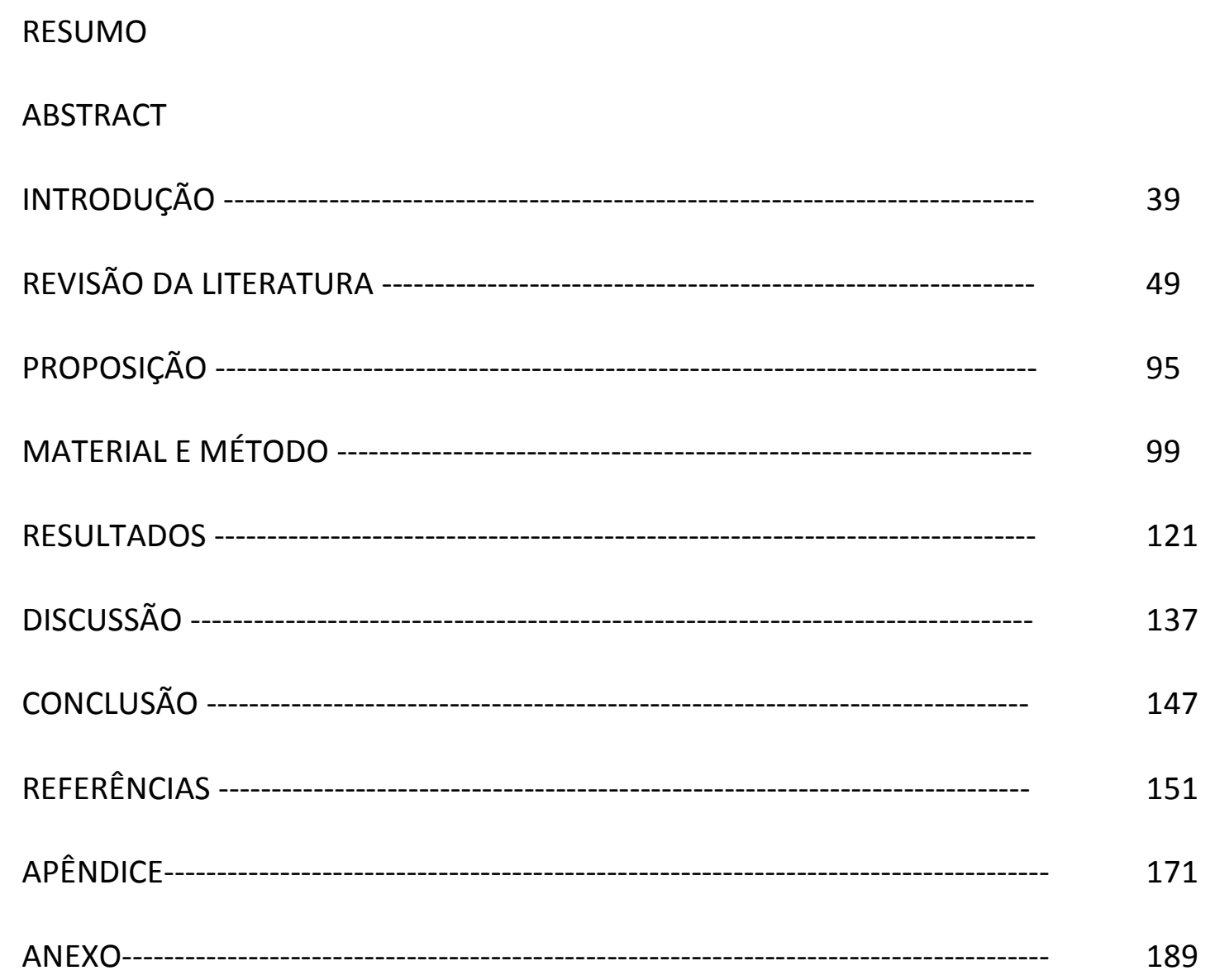





\section{Introdução}


O sucesso na terapêutica endodôntica está diretamente relacionado à obediência a todos os princípios que regem o tratamento dos canais radiculares, tais como a obtenção da limpeza, desinfecção, modelagem, de modo a permitir sua completa obturação tridimensional e restauração adequada do coroa. No entanto, este preparo é altamente influenciado pela variação anatômica existente nos canais (PETERS et al., 2003a; SCHILDER, 1974; VIVAN et al. 2010).

A complexa anatomia dos canais radiculares, com suas reentrâncias, canais laterais, acessórios, secundários, istmos, canais ovais, múltiplos forames e deltas apicais dificultam a limpeza e desinfecção completa do sistema endodôntico (NAIR et al., 2005; PETERS et al., 2003a; RICUCCI; BERGENHOLTZ, 2003; WU; WESSELINK, 2001).

Assim sendo, os instrumentos endodônticos, isoladamente, não possuem capacidade eficiente de limpar os canais radiculares, necessitando da utilização simultânea de soluções auxiliares durante sua utilização (ESTRELA et al. 2002; HAAPASALO et al. 2005; SIQUEIRA JR et al., 1997; WALTON, 1976).

Dentre os principais papéis desempenhados pela irrigação podemos citar entre outros, a remoção dos tecidos pulpares e sua dissolução; a remoção e neutralização tanto dos microrganismos quanto de seus subprodutos tóxicos, e ainda a remoção da smear layer das paredes dos canais radiculares, agindo também como lubrificante para os instrumentos endodônticos. (BAUGH; WALLACE, 2005; FIGDOR; SUNDQVIST, 2007; HAAPASALO et al. 2005).

O preparo biomecânico dos canais radiculares se dá por três meios: mecânico, químico e físico. Os meios mecânicos assumem, dentro desta fase, um papel de grande importância, pois uma correta modelagem do canal radicular permitirá que as soluções auxiliares, por meio da irrigação e aspiração, sejam efetivas em toda a extensão do canal radicular (BOUTISIOUKIS, 
et al., 2010; BRONECC; BOUILLAGUET; MACHTOU, 2010; NAIR et al., 2005). Desta forma, a desinfecção e limpeza do sistema de canais radiculares não dependem apenas da ação mecânica dos instrumentos, mas da ação destes em conjunto com a ação química promovida pelo emprego de soluções irrigantes dotadas de propriedades químicas como solvência de matéria orgânica e atividade antimicrobiana e, pela ação física da irrigação e aspiração. Esta última promovendo além do arrasto de irritantes; restos de sangue; detritos e raspas de dentina, tanto da câmara pulpar quanto dos canalículos dentinários. (FIGDOR; SUNDQVIST, 2007; HAAPASSALO et al. 2005; LOPES \& SIQUEIRA JR, 2004; MOORER; WESSELINK, 1982).

Com o intuito de avaliar o preparo e limpeza promovida pelo processo biomecânico dos canais radiculares, várias metodologias têm sido criadas, dentre elas: a) microscopia eletrônica de varredura que permite a visualização da presença ou ausência da camada de smear nas paredes dos canais radiculares (BERTRAND et al., 1999; DAI et al. 2011; GAMBARINI, 1999; SEIXAS et al., 2003; WILLIAMSON; SANDOR; JUSTMAN, 2009); b) microscopia óptica, capaz de caracterizar e quantificar por meio da análise morfométrica a presença de débris, área de pré-dentina, assim como a atuação ou não de um determinado instrumento ou solução auxiliar (BARBIZAN et al 2002; FARINIUK et al., 2003; MARCHESAN et al., 2003; PASSARINHO-NETO et al., 2006; SHIN et al., 2010); c) sobreposições de imagens radiográficas permitindo a avaliação do preparo e desvios apicais (VELTRI et al., 2005); d) utilização de muflas, que por meio de cortes transversais ou verticais e reposicionamento das raízes, permite a visualização do preparo em áreas de segurança, desvios antes e após o preparo (GUELZON et al., 2005; PAQUÉ; MUSCH; HULSMANN; 2005) e, mais recentemente, a análise tomográfica computadorizada, que por meio de cortes transversais possibilita a avaliação anatômica dos elementos dentários e 42 
adjacentes de forma não invasiva e em três dimensões. (GRANDE et al., 2008; PATÉL et al., 2009; PETERS, et al., 2003a)

No processo do preparo biomecânico, a limpeza do canal radicular é calculada pela presença de débris, que é formada por remanescentes de material orgânico ou inorgânico onde os instrumentos e/ou as soluções auxiliares não foram efetivas ou por um resíduo constituído por uma substância amorfa em forma de pasta que se adere em suas paredes, levando o nome de smear layer ou camada de smear, sendo esta última formada apenas nas áreas onde o instrumento manteve contato direto com as paredes dos canais radiculares (HULSMANN; GRESSMANN; SCHÄFERS, 2003; SASAKI et al., 2006; USMAN; BAUMGARTNER; MARSHALL, 2004).

Vários autores ressaltam a importância do conhecimento da anatomia interna dos canais radiculares para o sucesso do tratamento endodôntico (LOPES; SIQUEIRA JR, 2004; NAIR et al. 2005; RICUCCI; BERGENHOLTZ, 2003) e sugerem que o tamanho do alargamento apical pode ser importante para remoção eficiente dos microrganismos, pois, com a utilização de instrumentos mais calibrosos, menos microrganismos permaneceriam no interior do canal radicular sendo o processo de cura mais rápido e efetivo. (CARD et al., 2002; COLDERO et al., 2002; STEVEN et al., 2002).

Porém, o conceito de alargamento apical foi pouco estudado, alguns trabalhos (CARD et al., 2002; COLDERO, et al., 2002; FORNARI et al., 2010; HECKER et al., 2010; STEVEN et al., 2002; YARED; BOU DAGHER, 1994) relatam a influência do alargamento apical no sucesso ou fracasso da terapia endodôntica, ficando o curativo de demora supervalorizado e tido como solução para a eliminação de microrganismos remanescentes no interior do canal radicular após o preparo biomecânico. 
No entanto, em estudos sobre a correta detecção do diâmetro anatômico da região apical no comprimento de trabalho (CT), foi ressaltada a importância do preparo cervical, uma vez que esse procedimento tende a auxiliar na correta seleção do instrumento inicial, levando a um adequado alargamento do terço apical (BARROSO et al., 2005; IBELLI et al., 2007; PAQUÉ; ZEHNDER; MARENDING, 2010; PÉCORA et al., 2005; SCHMITZ et al 2008; WU et al., 2000).

A detecção, com precisão, do diâmetro anatômico in vivo ainda encontra limitações. $\mathrm{O}$ exame radiográfico, além de ser pobre em detalhes, não apresenta condições de medida do diâmetro dos canais radiculares, uma vez que se trata de uma imagem gerada em dois planos de uma estrutura com aspecto tridimensional. (EDER, et al., 2005; ESTRELA et al., 2008a; LOW et al., 2008; PAULA-SILVA et al., 2009).

Com o advento da tomografia computadorizada médica desde o seu desenvolvimento por Hounsfield em 1979, várias possibilidades se abriram para a visualização e estudo por meio de metodologia não invasiva das estruturas anatômicas em três dimensões, podendo ser utilizada tanto para análise qualitativa, quanto quantitativa, (SBERNA et al., 2009; SOMMA et al., 2009) tendo sido empregada na Endodontia apenas em 1990 por Tachibana \& Matsumoto. (BERGMANS et al., 2001)

Apesar deste avanço tecnológico, sua baixa difusão e utilização na comunidade odontológica foram determinadas por vários fatores limitantes tais como: altas doses de radiação para o paciente; baixa resolução das imagens para as exigências odontológicas; tamanho amplo do equipamento e a obrigatoriedade do paciente permanecer deitado para a realização do exame (LOW et al., 2008). Por esses motivos, Arai em 1997, pioneiramente utilizou e aprimorou a Tomografia Computadorizada cone beam tendo como objetivos: menor dose de radiação para o paciente, melhor qualidade de imagem com distinção de estruturas 44 
delicadas tais como esmalte, dentina, cavidade pulpar e cortical óssea; possibilitando ainda, a realização do exame com o paciente sentado, e em menor tempo, diminuindo a incidência de artefatos nas imagens ocasionada pela movimentação do paciente. (PATEL et al., 2009)

$\mathrm{Na}$ busca de melhores resultados nos preparos biomecânicos dos canais radiculares várias técnicas foram criadas, e dentre elas, a instrumentação rotatória mecanizada. Isto foi possível graças ao desenvolvimento de instrumentos flexíveis confeccionados a partir de uma liga de níquel-titânio, acionados por motores eletromecânicos ou pneumomecânicos (GAMBARINI; LASZKIEWICZ, 2002).

Esta evolução trouxe como benefício maior eficiência na remoção de débris, resultado da maior área de escape e da rotação contínua dos instrumentos, bem como, obtenção de maior rapidez nos preparos e redução do transporte, desvios, degraus e rasgos apicais (zip) do canal radicular (BECHELLI; ORLANDI; COLAFRANCESCHI, 1999; BERTRAND et al., 1999; FOSCHI et al., 2004; HÜLSMANN; SCHADE; SCHÄFERS, 2001; SCHÄFER, LOHMANN, 2002a e 2002b).

Mais recentemente foi desenvolvido um novo conceito no preparo dos canais radiculares, com o intuito de sanar as dificuldades encontradas pelo sistema rotatório de instrumentação dos canais, Self-Adjusting File ${ }^{\circledR}$ (ReDent-Nova, Ra'anana, Israel). Trata-se de um cilindro oco com o aspecto de uma fina rede de NiTi com irrigação constante, que se auto ajusta nas paredes dos canais. Este instrumento é acionado por uma peça de mão, que pela cinemática de vibração com entrada e saída, remove a dentina das paredes dos canais radiculares (METZGER et al., 2010).

Apesar das inovações tecnológicas, a limpeza dos canais radiculares principalmente na região apical, ainda não foi perfeitamente conseguida (BARBIZAN et al., 2002; FARINIUK 
et al., 2001; FARINIUK et al., 2003; FORNARI et al., 2010; FOSCHI et al., 2004; LIMONGI et al., 2007; RÖDGI et al., 2002; SEIXAS et al., 2003; SIQUEIRA JR et al., 1997).

Assim sendo, as soluções irrigantes auxiliares têm assumido papel importante no preparo biomecânico dos canais radiculares. Dentre as soluções irrigantes disponíveis na atualidade, o hipoclorito de sódio, nas mais diferentes concentrações, têm sido largamente recomendado e mundialmente aceito pelas suas propriedades: antimicrobiana; desodorizante; clarificadora; e na dissolução dos tecidos orgânicos (ESTRELA et al., 2002; FIGDOR \& SUNDKVIST, 2007; HAAPASALO et al. 2005; SPANÓ et al., 2001).

Além das propriedades físico-químicas inerentes a cada solução irrigante, a constante renovação da mesma durante o preparo biomecânico, por meio de diversas formas de irrigação-aspiração, evita sua saturação, bem como a precipitação de partículas e, ainda favorece a remoção dos detritos mantidos em suspensão no interior do canal radicular (BARBIN, 1999; ESTRELA et al., 2002; SIQUEIRA JR, et al., 2010; SPANÓ et al., 2001).

Outros fatores relacionados à irrigação podem influenciar na eficácia da solução tais como: volume; profundidade de penetração da agulha de irrigação; tempo de permanência da solução no interior do canal radicular; área de contato e, aquecimento da solução, que no caso do hipoclorito de sódio, potencializa a dissolução de tecido orgânico (ALBRECHT; BAUMGARTNER; MARSHALL, 2004; ESTRELA et al., 2002; GAMBARINI, 1999; MOORER; WESSELINK, 1982; WALTERS et al., 2002).

Os avanços tecnológicos durante a última década disponibilizaram novos aparelhos de agitação e mecanismos de irrigação da solução auxiliar, que juntamente com o preparo dos canais radiculares, promovem a remoção da smear layer e débris das paredes dos mesmos (GU et al., 2009; METZGER et al., 2010; SIQUEIRA JR, et al., 2010). Recentemente, um novo dispositivo de irrigação baseado na tecnologia de irrigação hidrodinâmica automática 46 
sob pressão e sucção foi introduzido no mercado (RinsEndo $\left.{ }^{\circledR}\right)$ e diversos estudos têm sido realizados para a averiguação deste novo mecanismo (CARON et al., 2010; HAUSER; BRAUN; FRENTZEN, 2007; McGILL et al., 2008; RÖDIG et al., 2010; VIVAN et al., 2010).

De acordo com Gu et al, (2009), os métodos de irrigação podem ser divididos em: 1) manuais, por meio de seringa hipodérmica tipo luer-lock com agulhas de diferentes calibres e aberturas, e cânulas aspiradoras (convencional), convencional com agulhas cobertas por escovas e, agitação dinâmica manual, sendo esta última, irrigação convencional com agitação da solução irrigante com movimentos de vai e vem com cone bem fino de guta percha; 2) sistemas auxiliares de agitação mecânica, tais como, escovas rotatórias; irrigação contínua durante a instrumentação; mecanismos sônicos; ultrassônicos e irrigação sob pressão $\left(\right.$ EndoVac $^{\circledR}$ e RinsEndo ${ }^{\circledR}$ ) (CAMERON, 1995; CARON et al., 2010; GU et al, 2009; HAUSER; BRAUN; FRENTZEN, 2007; RÖDIG et al., 2010; VAN DER SLUIS et al., 2007).

O preparo ultrassônico dos canais radiculares foi preconizado por Richman (1957), e desde então, o ultrassom tem sido exaustivamente estudado, posteriormente observou-se que o ultrassom não era capaz de executar todos os tempos operatórios do tratamento endodôntico, podendo, no entanto, ser considerado um importante instrumento auxiliar no processo de limpeza do sistema de canais radiculares (CAMERON, 1983; MARTIN \& CUNNINGHAM, 1982, VAN DER SLUIS et al., 2007).

O ideal, nas técnicas de instrumentação dos canais radiculares seria que os instrumentos tocassem todas as suas paredes e, desta forma, promovesse a limpeza e remoção dos microrganismos. Assim, para promover esse contato íntimo entre os instrumentos e as paredes dos canais radiculares, faz-se necessário detectar qual seria o primeiro instrumento a tocar 
todas as paredes, e a seguir, estabelecer quantos instrumentos seriam utilizados no ato cirúrgico. Além deste fato, deve-se investigar qual o método de irrigação seria mais eficiente na limpeza dos canais radiculares, principalmente em dentes com achatamento mésio-distal de raiz. 



\section{Revisão de Literatura}


Para melhor compreensão, a revisão da literatura foi dividida em: 1) Limpeza dos canais radiculares e morfologia apical; 2) Evolução do tomógrafo computadorizado na Odontologia.

\section{1) Limpeza dos canais radiculares e morfologia interna apical;}

O tratamento endodôntico na busca da excelência e sucesso na terapêutica se alicerça em vários fatores dentre eles, o preparo, limpeza ou desinfecção, modelagem e posterior obturação do sistema de canais radiculares.

Shilder (1974) inovou, apresentando o conceito de limpeza e modelagem dos canais radiculares (Cleaning and Shaping). O autor discorre sobre a importância do preparo dos canais radiculares de forma a se obter os princípios biológicos propondo sua limpeza e modelagem em toda a sua extensão, promovendo um preparo cônico para posteriormente facilitar a obturação "hermética" e tridimensional do sistema endodôntico.

Civijan et al. (1975) sugeriram, pela primeira vez, o uso das ligas de níquel-titânio para a confecção de instrumentos em Dentística, Cirurgia, Periodontia e Endodontia. Dentre as vantagens desta liga, estão à flexibilidade, baixo módulo de elasticidade, alta resiliência, memória de forma e maior resistência à deformação e corrosão.

Walton (1976) por meio de microscopia óptica avaliou a limpeza promovida nos canais radiculares estreitos e curvos por diferentes técnicas de instrumentação. Seus resultados mostraram que nenhuma técnica foi totalmente eficiente, principalmente nos terços apicais.

Kereks e Tronstand (1977a) analisaram morfometricamente, por meio da medição da largura das raízes e canais de 100 dentes anteriores humanos de estoque, a possibilidade de utilização de uma técnica estandardizada de preparo e obturação dos canais radiculares. Foram realizados cortes nas raízes a 1, 2, 3, 4 e 5 mm aquém do ápice radicular com máquina de corte fino, as secções foram analisadas por microscópio óptico equipado com uma ocular 
de medição. Os autores concluiram que o preparo circular pode ser realizado em incisivos laterais superiores e incisivos inferiores apenas ao nível de 1 milímetro aquém do ápice radicular.

Kereks e Tronstand (1977b) avaliaram morfometricamente o diâmetro anatômico dos canais radiculares de 40 molares superiores e inferiores, em cinco diferentes níveis, a partir do ápice com o objetivo de sugerir uma padronização na determinação do diâmetro cirúrgico durante o preparo biomecânico. Os autores concluíram que a ampliação apical com instrumentos de diâmetro de 0,25 ou $0,30 \mathrm{~mm}$ não permitiria uma limpeza adequada dos canais radiculares destes dentes estudados, sugerindo uma maior ampliação, visando incorporar o maior número das irregularidades anatômicas presentes.

Miyashita et al. (1997) avaliaram, por meio diafanização com salicilato de metila, a configuração, espessura e curvatura dos canais radiculares, condições dos canais acessórios localização do forame apical de 1085 incisivos inferiores de estoque. Os autores concluíram que para um preparo adequado, devido à espessura do canal principal na região apical e da curvatura radicular encontrada deve-se realizar o alargamento apical ate o instrumento \#40.

Walia et al. (1988) foram os pioneiros a utilizar a liga de NiTi na confecção de instrumentos para preparo dos canais radiculares, os autores compararam o desempenho de limas 15 tipo $\mathrm{K}$, de aço inox, e um protótipo de mesmo diâmetro confeccionado por micro usinagem a partir de um fio ortodôntico de níquel titânio. Os resultados mostraram maior resistência á fadiga torsional, flexibilidade elástica de 2 a 3 vezes superior em relação ao instrumento de aço inox e memória de forma. Com base em seus resultados, os autores sugeriram que a utilização desta nova liga para a confecção de instrumentos para o preparo dos canais radiculares seria viável, fato esse que somente ocorreu em 1992. 
Espósito; Cunningham (1995), em seus estudos, a partir de um método radiográfico, compararam a manutenção da forma original em canais radiculares curvos durante o preparo de 40 dentes humanos extraídos com instrumentos rotatórios de NiTi acionados mecanicamente, e instrumentos manuais, tanto confeccionados de aço inoxidável, quanto de NiTi. Os resultados mostraram que as limas de NiTi, tanto as rotatórias acionadas mecanicamente, quanto as manuais apresentaram resultados superiores na manutenção da trajetória original do canal radicular quando comparadas ao grupo dos instrumentos confeccionados de aço inoxidável.

Guerisoli et al. (1998) investigaram ação das soluções de hipoclorito de sódio em diferentes concentrações $(0,5 ; 1 ; 2,5$ e $5 \%)$ sobre a estrutura dentinária mineralizada e desmineralizada, por 1 hora. Os resultados mostraram que a dentina mineralizada apresentava perda de massa tecidual de modo estatisticamente semelhante para todas as concentrações das soluções estudadas. Porém, a dentina desmineralizada (colágeno) sofria perda de massa de modo diretamente proporcional à concentração da solução, quanto maior a concentração da solução de hipoclorito de sódio, maior era sua perda de massa.

Wu et al (2000) investigaram in vitro, por meio histológico, o diâmetro no terço apical de 180 dentes humanos extraídos quanto à prevalência e extensão de canais ovais. Os dentes foram seccionados a 1, 2, 3, 4 e $5 \mathrm{~mm}$ aquém do ápice radicular tendo seus diâmetros calculados por microscópio de mensuração com 30X de aumento. Os autores concluíram que canais ovais longos eram comuns nos 5 milímetros apicais dos dentes humanos, e afirmaram que, a instrumentação completa, tanto dos canais ovais estreitos, quanto os largos seria impossível de ser realizada sem perfurar ou enfraquecer as raízes, e que cuidados deveriam ser tomados na limpeza, modelagem e obturação desses canais. 
Spanó et al. (2001) avaliaram in vitro o efeito de quatro concentrações de hipoclorito de sódio $(0,5,1,2,5$ e $5 \%)$ na dissolução tecidual de polpa bovina em temperatura ambiente, o nível residual de cloro, $\mathrm{pH}$ e tensão superficial antes e após a dissolução dos tecidos. Para tanto, fragmentos de polpa bovina foram imersos nas soluções por meio de um sistema que fazia circular a solução. Os autores concluíram que quanto maior a concentração da solução de hipoclorito de sódio, mais rápido era a dissolução do tecido pulpar, que todas as soluções tiveram seu pH e tensão superficial reduzidos, e que as soluções com altas concentrações tiveram o mínimo de consumo de cloro durante a dissolução tecidual, também afirmaram que o cloro residual posteriormente a reação foi encontrado em todas a situações estudadas, e que sua quantidade foi diretamente proporcional à concentração utilizada.

Wu; Wesselink (2001) analisaram a qualidade da obturação nas áreas de recesso não preparadas em canais ovais de incisivos inferiores instrumentados pela técnica manual da força balanceada. Os dentes foram divididos em dois grupos, sendo que no primeiro os dentes foram instrumentados até o diâmetro convencional e no outro, as amostras foram preparadas de maneira bem mais ampla que os dentes do grupo anterior. Todos os canais foram obturados pela técnica de condensação lateral fria da guta percha e analisados pelo sistema de imagem $\mathrm{KS}_{100}{ }^{\circledR}$. Os autores concluíram que as áreas de recesso nos dentes portadores de raízes ovais podem ser não instrumentadas pela técnica das forças balanceadas, e essas podem não ser completamente obturadas pela técnica de condensação lateral da guta percha.

Barbizam et al. (2002) estudaram in vitro por meio de análise morfométrica a limpeza promovida em dentes incisivos portadores de achatamento mésio-distal. Para tanto, 20 incisivos inferiores foram utilizados e separados em 2 grupos contendo 10 dentes cada. No grupo 1, os dentes foram preparados por meio de limas rotatórias de NiTi (ProFile ${ }^{\circledR}$ 04) acionadas mecanicamente pela técnica crown down até a lima \#40, e o segundo grupo, os 
dentes foram preparados pela mesma técnica do primeiro grupo, mas com limas manuais de aço inoxidável (Tipo K) até a lima \#40. Os autores verificaram que houve ineficiência de instrumentação em ambos os grupos. Constataram também que a técnica manual apresentou melhores resultados na limpeza dos canais radiculares em comparação à técnica rotatória

Card et al. (2002) avaliaram em seus estudos se o alargamento em diâmetros maiores que os convencionais são mais efetivos na diminuição bacteriana nos canais radiculares. Foram selecionados 40 pacientes com evidências clínicas e radiográficas de periodontite apical, dentre esses, 2 dentes caninos inferiores, 11 dentes pré-molares (primeiros e segundos) e 27 molares. A coleta bacteriana foi realizada após o acesso e em seguida a cada instrumentação. Foi realizada primeiramente a instrumentação dos canais com o sistema ProFile $^{\circledR} .04$ (serie 29) e hipoclorito de sódio a 1\% até a lima \#7 (0.465 mm) para os canais mesiais dos molares e até a lima \#8 $(0,599 \mathrm{~mm})$ para os caninos e pré-molares inferiores. Posteriormente realizou-se instrumentação dos canais radiculares com o sistema LigthSpeed ${ }^{\circledR}$ e hipoclorito de sódio a 1\%, alargando até a lima \#65, nos canais mesiais dos molares, sendo que o alargamento indicado seria até a lima \#57,5; e nos caninos e pré-molares até a lima \#100, sendo que o diâmetro normalmente utilizado seria o \#80. Os resultados mostraram diferença estatística significante entre as amostras colhidas antes e após a primeira e segunda instrumentação. Entre a primeira e segunda instrumentação, não houve diferença estatística significante quanto às amostras colhidas. Os autores concluíram que tanto a primeira instrumentação, quanto à segunda, poderiam gerar em sistemas de canais radiculares simples (sem comunicações múltiplas visíveis) canais com menos microrganismos.

Coldero et al. (2002) compararam in vitro a redução microbiana intracanal utilizando instrumentos rotatórios de níquel-titânio $G T^{\circledR}$ e ProFile ${ }^{\circledR} .04$ com e sem alargamento apical associados à irrigação com hipoclorito de sódio a 4,4\% e irrigação final com EDTA a 15\% 
por 3 minutos. Para tanto, 38 raízes palatinas de molares superiores foram utilizadas e esterilizadas, posteriormente foi inoculado em seu interior Enterococus Faecalis. Os espécimes foram em divididos em 2 grupos experimentais A e B (16 dentes cada) e um grupo C (6 dentes) como controle. No grupo A foi realizada instrumentação coma as limas $G T$ Rotary Files $^{\circledR}$ pela técnica crown down até a lima 20/.06 e posterior instrumentação com limas ProFile ${ }^{\circledR}$ 20/.04, 25/.04 30/.04 e alargamento final com lima 35/.04, no grupo B, a mesma instrumentação do grupo A foi realizada até a lima $G T^{\circledR} 20 / .06$, posteriormente realizou-se o preparo step-back com limas ProFile ${ }^{\circledR} .04$ recuando-se os instrumentos de 0,25 em $0,25 \mathrm{~mm}$ de modo que a lima 35/.04 ficasse a $1 \mathrm{~mm}$ do comprimento de trabalho, quanto ao grupo C, não foi realizada instrumentação, apenas irrigação com a mesma solução e volumes dos grupos anteriores. Os autores concluíram que não houve diferença estatística significante experimental com e sem o alargamento apical na redução intracanal do número de microrganismos.

Estrela et al. (2002) discutiram por meio de uma extensa revisão, os mecanismos de ação do hipoclorito de sódio, utilizado como auxiliar no tratamento endodôntico dos canais radiculares como solução irrigadora baseado em suas propriedades antimicrobianas e físicoquímicas. Os autores afirmaram que esta solução tem sido mundialmente aceita e empregada pela maioria dos pesquisadores e profissionais nas mais variadas concentrações por apresentar as propriedades necessárias para a limpeza e desinfecção do sistema endodôntico uma vez que promovem alterações celulares, alterações no metabolismo celular e na destruição dos fosfolipídios, pela formação de cloraminas que interferem no metabolismo celular, pela ação oxidante com inibição enzimática irreversível nas bactérias, e pela degradação de ácidos graxos e lipídeos. 
Walters, Baumgartner e Marshall (2002) avaliaram in vitro, por meio da microscopia óptica, a limpeza e remoção de débris das paredes dos canais radiculares de dentes humanos uniradiculares de estoque preparados pela instrumentação rotatória com limas ProFile ${ }^{\circledR}$ taper. 04 (Dentsply, Suíça) pela técnica crown down até a lima \#40 associado à irrigação convencional (grupo A) ou com sistema de irrigação Quantec- $E^{\circledR}$ (grupo B) com solução de hipoclorito de sódio a 2,5\% na. As análises histológicas foram realizadas a 1, 3 e 5 mm aquém do ápice radicular. Os resultados constataram maior quantidade de débris a $1 \mathrm{~mm}$ em comparação a 3 ou a $5 \mathrm{~mm}$ aquém do ápice radicular no grupo $\mathrm{A}$, quanto ao grupo $\mathrm{B}$, não houve diferença estatística significante entre os níveis estudados. Em ambos os grupos, a 5 mm aquém do ápice radicular, não houve diferença estatística significante na quantidade de débris remanescente. Quanto ao tempo e volume da solução utilizada, o grupo B apresentou diferença estatisticamente significante demonstrando menor tempo e maior volume de solução utilizado para o preparo dos canais radiculares.

Wu et al. (2002) estudaram a relação entre o diâmetro anatômico (DA) do canal e o primeiro instrumento a atingir e se adaptar no comprimento de trabalho. Para tanto, 20 prémolares inferiores humanos de estoque, limas tipo $\mathrm{K}$ e instrumentos LightSpeed $^{\circledR}$, foram utilizados. Ao adaptar-se ao comprimento de trabalho, o instrumento era então fixado e seu ápice radicular desgastado até o aparecimento do instrumento, de modo que o diâmetro do instrumento e do canal pudessem ser mensurados e comparados. Os resultados mostraram que, em $75 \%$ das amostras, os instrumentos tocavam em apenas um lado das paredes dos canais radiculares, e quanto os $25 \%$ restantes, os instrumentos não tocavam nenhuma das paredes. Em 90\% das amostras o diâmetro do instrumento era menor que o menor diâmetro do canal naquele ponto. Os autores concluíram que nenhum dos instrumentos conseguiu expressar com precisão, o diâmetro anatômico real no terço apical, questionaram também, se 
o aumento do diâmetro em três instrumentos acima do diâmetro da lima que determinou o DA, seria suficiente para o preparo das paredes do canal radicular.

Tan e Messer (2002) compararam, por meio histológico, a ação das limas tipo $\mathrm{K}^{\circledR}$ e o sistema Lightspeed ${ }^{\circledR}$, quanto à limpeza, transporte e à forma dos canais mesio-vestibulares de molares inferiores. Os resultados mostraram que a instrumentação com o sistema Lightspeed $^{\circledR}$ permitiu uma ampliação apical maior, com canais significativamente mais limpos, um menor transporte apical e melhor modelagem do canal radicular. Entretanto, nenhuma das técnicas estudadas foi capaz de promover canais totalmente limpos.

Ricucci e Bergenholtz (2003) analisaram, por meio histológico, as condições microbianas dos canais radiculares obturados de dentes que foram expostos por período prolongado ao ambiente oral por perda de restauração e fratura ou por processos cariosos por pelo menos um tempo de três meses. Para tanto um total de trinta e dois dentes foram radiografados e extraídos por não comportar mais restaurações. As amostras foram processadas e analisadas histologicamente. Os autores concluíram que canais bem instrumentados e obturados são mais resistentes à penetração de microrganismos quando expostos a cavidade oral mesmo por períodos prolongados.

Seixas et al. (2003) avaliaram a remoção da camada de smear de 40 dentes incisivos inferiores portadores de achatamento mésio-distal após a instrumentação rotatória e submetidos à aplicação do laser da alta potência. Para tanto, os dentes foram divididos e 4 grupos: grupo 1, instrumentação rotatória auxiliado por hipoclorito de sódio a 2,5\%, grupo 2, como o grupo 1, mais a irradiação do laser Er: YAG (140 mJ input/10Hz com deslocamento de fibra de apical para cervical $(2 \mathrm{~mm} / \mathrm{s})$ na parede lingual e posteriormente na vestibular), grupo 3, o mesmo que o grupo 2, mas com parâmetro de Laser diferente (250 mJ input/ 10Hz) e o grupo 4 instrumentado como o grupo 1, associando o hipoclorito de sódio a 2,5\% ao 
EDTA a $17 \%$. Os dentes foram seccionados longitudinalmente e as amostras foram analisadas no microscópio eletrônico de varredura. Os resultados mostraram que o grupo 4 apresentou menores quantidades de smear seguidos pelo grupo 3, 2 e por último o grupo 1, mostraram também, que o terço apical apresentou maiores quantidades estatisticamente significantes ( $\mathrm{p}<0,001)$ em comparação com o terço médio.

Setlock et al. (2003) avaliaram, por meio da microscopia eletrônica de varredura, a limpeza dos canais radiculares e remoção da smear layer após a utilização do sistema Quantec- $E^{\circledR}$ de irrigação comparado ao sistema convencional. Desta forma, foram utilizados 40 dentes humanos anteriores superiores de estoque, os quais foram divididos em 4 grupos: grupo A (15 dentes), instrumentação pela técnica crown down com limas de NiTi Quantec ${ }^{\circledR}$ (Analitic, Califórnia, USA) até o taper .04 e irrigados simultaneamente pelo sistema Quantec$E^{\circledR}$ (Analitic, Califórnia, USA) de irrigação com $12 \mathrm{ml}$ de solução de hipoclorito de sódio a 5,25\% seguido por $6 \mathrm{ml}$ de solução de EDTA a 17\% com irrigação final por $4 \mathrm{ml}$ de solução de hipoclorito de sódio a 5,25\%; grupo B, (15 dentes) instrumentação pela mesma técnica do grupo A, e irrigação pelo método convencional (seringa e agulha) com o mesmo volume de solução do grupo anterior; grupo C (5 dentes) não receberam instrumentação (grupo controle negativo); grupo D (5 dentes) instrumentação pela mesma técnica dos grupos A e B, mas sem irrigação dos canais radiculares (grupo controle positivo). Os espécimes foram seccionados no sentido vestíbulo-lingual e analisados com $700 \mathrm{X}$ de aumento. Os resultados mostraram que o sistema Quantec- $E^{\circledR}$ de irrigação apresentou melhores resultados na remoção da camada de smear e débris comparado ao sistema convencional apenas no terço coronário, quanto aos outros terços, não foram encontradas diferenças estatísticas significantes.

Foschi et al. (2004) avaliaram, por meio de M.E.V, a limpeza e preparo das paredes dos canais radiculares promovida pelos sistemas rotatórios $M t w o^{\circledR}$ e ProTaper $^{\circledR}$ auxiliados pela 
irrigação com $1 \mathrm{ml}$ de solução de hipoclorito de sódio a $5 \%$, seguido de $1 \mathrm{ml}$ de solução de água oxigenada a $3 \%$ e $0,5 \mathrm{ml}$ de EDTA a $10 \%$ a cada troca de instrumento, finalizando o preparo com irrigação com solução de EDTA a 17 \% e solução de hipoclorito de sódio em vinte e quatro dentes uniradiculares humanos de estoque. Os autores concluíram que ambos os sistemas, auxiliadas pela irrigação, promoveram limpeza e remoção de débris e smear layer nos terços cervicais e médios, mas não foram eficazes no terço apical. Afirmaram que a presença de canaletas profundas e depressões nos terços apicais podem explicar a presença de áreas não instrumentadas.

Peters (2004) por meio de uma extensa revisão sobre os desafios e conceitos no preparo do sistema de canais radiculares identificou os fatores que influenciam os resultados no preparo com instrumentos de níquel-titânio, tais como conhecimento de anatomia interna e desenho da ponta do instrumento, assim como a experiência requerida pelo operador, velocidade de rotação e sequência de instrumentação para minimizar a ocorrência de fraturas, zips ou transportes dos canais radiculares. Os resultados demonstraram que a incidência do transporte, infiltração e erros de preparo utilizando instrumentos rotatórios de NiTi foram muito menores, quando comparados á instrumentação manual com limas de aço-inox, produzindo melhores resultados na obturação. $\mathrm{O}$ autor concluiu que a instrumentação rotatória com limas de NiTi é uma importante ferramenta na terapêutica endodôntica.

Peters, Barbakow e Peters (2004) avaliaram, por meio radiográfico in vivo, os resultados clínicos obtidos pelos tratamentos endodônticos realizados com sistemas rotatórios de NiTi (a- Lightspeed ${ }^{\circledR}$, b- ProFile ${ }^{\circledR} .04$, c- ProFile .04 e .06 ou instrumentos $G T^{\circledR}$ ) de 233 dentes por um período aproximado de 25,4 $\pm 11,8$ meses. Nos grupos (a) e (b) a obturação dos canais foi realizada pela técnica de condensação lateral da guta percha e cimento $A H-P l u s^{\circledR}$, no grupo (c), a obturação foi realizada pelo System $B^{\circledR}$ e Obtura $I I^{\circledR}$ e cimento Roths ${ }^{\circledR}$ 801. Os 
resultados mostraram um prognóstico favorável em $86,7 \%$ das amostras. Os retratamento e os dentes que apresentavam lesões periapicais demonstraram um menor índice de sucesso do que os dentes que não apresentavam comprometimento periapical. Os autores concluíram que na técnica de preparo, o limite apical de obturação e o tipo de cimento obturador utilizado não afetou significantemente o índice de sucesso.

Schäfer e Vlassis (2004) avaliaram, por meio de M.E.V., a capacidade de limpeza e a habilidade na modelagem dos sistemas rotatórios ProTaper $^{\circledR}$ e $R a C e^{\circledR}$ em canais radiculares curvos de dentes extraídos. Os resultados evidenciaram que nenhum canal mostrou-se completamente limpo em nenhum dos grupos. Entretanto, para a remoção de débris, o sistema $R a C e^{\circledR}$ mostrou-se significativamente mais eficiente do que o ProTaper $^{\circledR}$. Para a remoção de smear layer não houve diferença estatística entre os dois sistemas rotatórios. O sistema $R a C e^{\circledR}$ manteve significativamente melhor a curvatura original do canal radicular do que o ProTaper $^{\circledR}$. E por fim, não houve diferença do tempo de trabalho entre os dois sistemas rotatórios. Com base nos resultados encontrados, os autores puderam concluir que os instrumentos $R a C e^{\circledR}$ promoveram maior limpeza e mantiveram melhor a curvatura original do canal radicular do que o sistema ProTaper ${ }^{\circledR}$.

Usman, Baumgartner e Marshall (2004) compararam, por meio da análise histológica, a eficácia do desbridamento do canal radicular no terço apical $(3 \mathrm{~mm})$ quando preparado no comprimento de trabalho, com instrumentos rotatórios de níquel-titânio (Greater Taper $\left.G T^{\circledR}\right)$ de números 20 e 40 utilizando as soluções irrigantes $\mathrm{NaOCl}$, EDTA e $R C$-Prep ${ }^{\circledR}$. Os dentes utilizados foram extraídos, descalcificados e secionados a $0,5 \mathrm{~mm}, 1,5 \mathrm{~mm}$ e a $2,5 \mathrm{~mm}$ do ápice radicular para análise histológica e quantificação da presença de débris. Não foi encontrada diferença estatística significante entre as distâncias do ápice no grupo de mesmo calibre do batente apical, entretanto, no grupo instrumentado com o instrumento $G T^{\circledR} \# 20$ 
apresentou significantemente mais débris do que no grupo instrumentado até o $G T^{\circledR} \# 40$. Baseado nestes resultados, os autores concluíram que a profundidade da penetração da agulha de irrigação não influenciou na limpeza dos canais, contradizendo o que muitos autores relatam. Porém, ao aumentar o diâmetro do batente apical houve um aumento significativo da remoção de débris na região apical.

Baugh e Wallace (2005) realizaram extensa revisão embasados nos achados mais recentes na literatura sobre a influência do aumento do diâmetro apical cirúrgico em relação às características anatômicas desta região bem como a redução microbiana, baseados em evidências clínicas. Os autores concluíram que pela variação anatômica existente nessa região, deveria ser fornecida ao clínico, uma estratégia de escolha, de modo a permitir maior facilidade de decisão na correta ampliação apical, e que mais pesquisas deveriam ser realizadas de modo a complementar as já existentes quanto às dificuldades ainda nas resoluções da terapia endodôntica.

Barroso et al. (2005) avaliaram in vitro, por meio de Microscopia eletrônica de varredura, a influência no preparo cervical do instrumento apical inicial (IAI) no comprimento de trabalho (CT) nas raízes vestibulares de 50 pré-molares superiores. Os dentes foram divididos em cinco grupos: no grupo 1, não foi realizado o preparo cervical e médio, nos grupos 2 a 5 foi realizado preparo cervical e médio respectivamente por: brocas de GatesGlidden, $K_{3}{ }^{\circledR}$ orifice opener instruments, ProTaper ${ }^{\circledR}$ instruments e brocas LA Axxess ${ }^{\circledR}$. Os autores concluíram que a determinação do diâmetro apical (DA) no CT não é precisa, que o pré-alargamento, e os instrumentos que o realizaram nos terços cervicais e médios melhoraram os resultados na determinação do DA. e que o grupo que sofreu pré-alargamento por meio das brocas LA. Axxess ${ }^{\circledR}$ demonstraram mais precisão na determinação do DA. 
Guelzow et al (2005) compararam in vitro, vários parâmetros de instrumentação dos canais radiculares de 147 molares inferiores utilizando para isso instrumentação manual com alargadores e limas hedströen e, rotatórias por meio de limas de NiTi (FlexMaster ${ }^{\circledR}$, System $G T^{\circledR}$, HERO $642^{\circledR}, K 3^{\circledR}$, ProTaper $^{\circledR}$ e RaC $\left.e^{\circledR}\right)$. As amostras foram incluídas em sistemas de muflas e posteriormente foram preparadas até a lima \#30 pela técnica crown down para os sistemas rotatórios e convencional para a manual, em seguida foram avaliados quanto à presença de desvios, transportes e perda de comprimento assim como o tempo necessário para a finalização do preparo. Os autores concluíram que todos os sistemas rotatórios com instrumentos de NiTi promoveram a manutenção das curvaturas dos canais radiculares com poucas fraturas de instrumentos e, em menor tempo de preparo quando comparados à técnica manual de instrumentação e que o sistema ProTaper $^{\circledR}$ promoveu preparos mais regulares.

Haapasalo et al. (2005) realizaram extensa revisão de literatura sobre oque há de mais recente e relevante sobre o efeito do preparo biomecânico dos canais radiculares sobre a infecção microbiana de canais necrosados, promovendo uma discussão desde a composição da microflora encontrada nas infecções endodônticas , soluções irrigantes empregadas no preparo, assim como instrumentação dos canais radiculares, tamanho do preparo apical e comprimento de trabalho, limpeza e desinfecção do sistema endodôntico e fraturas de instrumentos, levando o leitor à busca da melhor estratégia para resolução dos casos clínicos.

Nadalin (2005) avaliou, histológica e morfometricamente, a remoção de débris do terço apical de canais radiculares achatados utilizando diferentes protocolos de irrigação final com seringa luer-lock. Foram utilizados trinta incisivos inferiores humanos de estoque preparados pelo sistema HERO $642^{\circledR}$ pela técnica crown down até a lima 40/.02 e irrigados durante o preparo biomecânico com $\mathrm{NaOCl}$ a $1 \%$. Posteriormente os dentes foram divididos em 4 grupos seguindo o seguinte protocolo de irrigação final: GI irrigação com $10 \mathrm{ml}$ de água 
destilada. GII e GIV irrigação com $10 \mathrm{ml}$ de $\mathrm{NaOCl}$ a $1 \%$ e a 2,5\%, respectivamente, agindo no interior do canal radicular por 8 minutos. GIII e GV irrigação com $\mathrm{NaOCl}$ a $1 \%$ e a 2,5\%, respectivamente, da seguinte maneira: o canal foi irrigado com $2 \mathrm{ml}$ de solução, que agiu por 2 minutos no interior do canal radicular. Repetiu-se o procedimento por mais quatro vezes, totalizando $10 \mathrm{ml}$ de solução e oito minutos de ação no interior do canal, considerando que na última aplicação a solução não permaneceu no interior do canal. Após a irrigação final os terços apicais foram submetidos ao processamento histológico. Não foi encontrada diferença estatística significante entre os grupos testados. O autor concluiu que todos os protocolos de irrigação final apresentaram comportamentos similares na remoção do débris no terço apical dos canais radiculares com achatamento mésio-distal de raiz.

Nair et al. (2005) avaliaram in vitro por meio de microscopia eletrônica de varredura a situação microbiana do sistema de canais radiculares nas raízes mesiais de molares inferiores com lesão periapical, imediatamente após o tratamento endodôntico, em sessão única, utilizando limas de aço inox pela técnica step-back até a lima \#25, ou instrumentação rotatória com limas LightSpeed ${ }^{\circledR}$ (Lightspeed Technology, USA) de NiTi até a lima \#40. Os resultados mostraram o insucesso de ambas às técnicas na remoção dos microrganismos das áreas de difícil acesso da complexa anatomia interna dos canais radiculares em sessão única.

Paqué, Musch e Hulsmann (2005) compararam in vitro por meio da microscopia eletrônica de varredura a limpeza, manutenção da curvatura e tempo necessário para o preparo dos canais radiculares de 50 molares inferiores instrumentados pelo sistemas rotatórios Race ${ }^{\circledR}$ e ProTaper $^{\circledR}$. As amostras foram inseridas em muflas para posterior análise dos resultados dos preparos nas paredes dos canais radiculares. Os autores concluíram que ambos os sistemas respeitaram a curvatura original dos canais de modo seguro e, que ambos os sistemas apresentaram resultados insatisfatórios de limpeza das paredes dos canais radiculares. 
Pécora et al. (2005) investigaram in vitro, por meio de lupa estereoscópica, a influência do preparo cervical e médio de 40 dentes incisivos superiores por diferentes instrumentos (Gates-Glidden, Quantec Flare $^{\circledR}$ series, LA. Axxess ${ }^{\circledR}$ ) na determinação do primeiro instrumento que se adaptou às paredes dos canais radiculares no comprimento de trabalho (CT). Os autores concluíram que a determinação do diâmetro apical (DA) no CT não é precisa, que o pré-alargamento e os instrumentos que o realizaram nos terços cervicais e médios melhoraram os resultados na determinação do DA. E que o grupo que sofreu préalargamento por meio das brocas $L A$. Axxess ${ }^{\circledR}$ demonstraram mais precisão na determinação do DA.

Vanni et al. (2005) investigaram in vitro, por meio de Microscopia eletrônica de varredura, a influência no preparo cervical do instrumento apical inicial (IAI) no comprimento de trabalho (CT) nas raízes mésio-vestibulares de 50 molares superiores com curvaturas de raiz entre 10 e $15^{\circ}$. Os dentes foram divididos em cinco grupos: no grupo 1, não foi realizado o preparo cervical e médio, nos grupos 2 a 5 foi realizado preparo cervical e médio respectivamente por: brocas de Gates-Glidden, $K_{3}^{\circledR}$ orifice opener instruments, ProTaper ${ }^{\circledR}$ instruments e brocas LA Axxess ${ }^{\circledR}$. Os autores concluíram que o pré-alargamento, e os instrumentos que o realizaram nos terços cervicais e médios melhoraram os resultados na determinação do DA. E que o grupo que sofreu pré-alargamento por meio das brocas $L A$. Axxess $^{\circledR}$ demonstraram mais precisão na determinação do DA.

Veltri et al.(2005) analisaram in vitro a habilidade de preparo de dois sistemas rotatórios de NiTi $\left(\right.$ Mtwo $^{\circledR}$ e EndoFlare-Hero Shaper $\left.{ }^{\circledR}\right)$ em canais radiculares curvos de 30 molares. Foram realizadas radiografias antes e após o preparo utilizando plataforma radiográfica. A dentina removida em 5 posições ao longo dos canais, simetria de preparo e presença de aberrações foram analisadas por meio de computador. Os autores concluíram que ambos os 
sistemas foram efetivos no preparo dos canais curvos de dentes extraídos promovendo remoção uniforma da dentina e preparo simétrico dos canais radiculares.

Sasaki et al. (2006) analisaram in vitro, por meio da microscopia óptica, a remoção dos remanescentes de débris no terço apical de canais vitais e não vitais com achatamento radicular após preparo biomecânico com instrumentos rotatórios de NiTi. Foram utilizados 18 dentes incisivos inferiores humanos de estoque recentemente extraídos, os quais foram divididos em 2 grupos de 9 dentes cada de acordo com o diagnóstico de polpa vital ou necrosada. Os canais foram instrumentados pelas limas ProTaper ${ }^{\circledR}$ (Dentsply, Suíça) pela técnica do fabricante e irrigados com hipoclorito de sódio a $1 \%$. Posteriormente os dentes foram submetidos ao processo histológico para avaliação dos resultados, os quais demonstraram não haver diferença estatística significante $(p>0,05)$ entre os dentes com polpa vital e necrosada. Os autores concluíram que a condição da polpa dental não interferiu na quantidade de débris remanescentes no terço apical dos canais portadores de achatamento de raiz preparados com limas rotatórias de $\mathrm{NiTi}$.

Figdor e Sundqvist (2007) escreveram uma extensa revisão sobre o papel do tratamento endodôntico na microflora microbiana do sistema de canais radiculares. Os autores discorreram sobre a seleção natural dos microrganismos provenientes da cavidade oral para os canais radiculares, assim como sua nutrição; a flora tanto dos canais não tratados, quanto nos canais obturados; microbiologia dos canais com infecção persistente; diferenças ecológicas entre os canais radiculares não tratados e os obturados; propriedades das espécies associadas à doença endodôntica persistente; condições para a manutenção das infecções; importância da assepsia; efeito antimicrobial do desbridamento; eficácia antimicrobial da instrumentação manual e rotatória mecanizada com limas de NiTi; o papel do alargamento na eliminação da infecção endodôntica e suas implicações clínicas; efeito antimicrobial dos agentes químicos, 
irrigação e curativos medicamentosos. Os autores concluíram que a infecção endodôntica não é um evento aleatório, a composição da microflora se desenvolve segundo as características do ambiente, necessárias para a instalação da infecção. A diminuição dos microrganismos dos canais radiculares infectados proporciona a situação ideal para o sucesso na terapêutica, e este pode ser alcançada pelo preparo mecânico com instrumentos estéreis, em conjunto com soluções antimicrobianas irrigantes como hipoclorito de sódio alternado com EDTA, auxiliados pelos curativos medicamentosos a base de hidróxido de cálcio.

Grande et al. (2007) avaliaram se o preparo de canais radiculares com conformação oval por meio de duas técnicas distintas resultariam em diferenças morfológicas significantes. Para tanto foram utilizados 40 pré-molares inferiores divididos em dois grupos, no primeiro grupo, os dentes foram instrumentados pelo sistema $A E T^{\circledR}$ oscilatório e o outro grupo utilizou o sistema ProTaper $^{\circledR}$. As amostras foram inseridas em muflas e as modificações nos diâmetros, nas áreas de superfície, e alterações da relação vestíbulo-lingual e mésio-distal foram analisadas. Os autores concluíram que os sistemas produziram diferenças significantes na forma final no terço cervical e médio, cabendo ao sistema $A E T$ os maiores índices de remoção de estrutura dental, quanto ao terço apical, não houve diferença estatística significante.

Hauser, Braun e Frentzen (2007) investigaram a eficiência de profundidade de penetração do sistema de irrigação hidrodinâmica comparado às técnicas convencionais de irrigação dos canais radiculares. Para tanto, 45 dentes uniradiculares foram instrumentados até a lima 30 taper.02 no comprimento de trabalho (1 $\mathrm{mm}$ aquém do ápice radicular), os dentes foram divididos em 3 grupos: grupo I, aplicação estática (a agulha não foi inserida no canal radicular) da solução irrigante de hipoclorito de sódio a $2 \%$, a solução foi deixada no canal radicular por três minutos; grupo II irrigação convencional com seringa e agulha no canal radicular com a mesma solução do grupo anterior (volume de $5 \mathrm{ml}$ ), a qual foi deixada no 
interior do canal radicular por 1 minuto, e grupo III, irrigação hidrodinâmica por meio do sistema RinsEndo ${ }^{\circledR}$ (Durr dental, Alemanha) com a mesma solução dos grupos anteriores por 50 segundos. Posteriormente, realizou-se irrigação com uma solução evidenciadora composta por hipoclorito de sódio a $2 \%$ e fucsina ácida. As raízes foram seccionadas transversalmente a 2, 4, 6 e $8 \mathrm{~mm}$ de seus respectivos ápices e a profundidade de penetração do corante mensurada. Os autores concluíram que a irrigação hidrodinâmica apresentou melhores resultados de penetração nos canalículos dentinários, em contra partida, apresentou também alto risco de extrusão apical, quando comparado aos outros grupos testados.

Ibelli et al. (2007) investigaram, por meio de lupa estereoscópica, a influência do preparo cervical e médio de 40 dentes incisivos laterais superiores ex vivo por diferentes instrumentos (nickel-titanium orifice opener instruments, Gates-Glidden e brocas LA. Axxess $^{\circledR}$ ) na determinação do primeiro instrumento que se adaptou às paredes dos canais radiculares no comprimento de trabalho (CT). Os autores concluíram que a determinação do diâmetro apical (DA) no CT não é precisa, que o pré-alargamento, e os instrumentos que o realizaram nos terços cervicais e médios melhoraram os resultados na determinação do DA. E que o grupo que sofreu pré-alargamento por meio das brocas LA. Axxess ${ }^{\circledR}$ demonstraram maior precisão na determinação do DA.

López et al. (2008) avaliaram, por meio de sobreposições de imagens digitalizadas, o transporte apical de raízes mesio-vestibulares de 60 molares montadas em sistemas de muflas. Os espécimes foram instrumentados com limas manuais triple-flex ${ }^{\circledR}$ de aço-inox pela técnica manual ou por meio de sistema oscilatório (NSK, Japão) e sistema rotatório mecanizado com limas de NiTi $K_{3}{ }^{\circledR}$ (Sybronendo, USA) até a lima 30, 35 ou 40. Os resultados mostraram que os grupos que utilizaram limas de aço-inox até as limas 35 e 40 apresentaram 
significantemente mais transporte apical em comparação ao grupo que utilizou limas de NiTi, o qual apresentou preparo apical seguro com baixo índice de transporte.

McGill et al. (2008) compararam in vitro, a eficácia da remoção da película biomolecular de 30 dentes uniradiculares humanos de estoque, portadores de achatamento de raiz, pelos métodos: convencional com seringa e agulhas (estática), convencional com agitação da solução (manual dinâmica) e dinâmica automática (RinsEndo ${ }^{\circledR}$ ) em 2 profundidades de inserção da agulha nos canais radiculares. Os autores concluíram que a irrigação dinâmica automática foi significantemente mais efetiva (16\%) que a irrigação convencional (estática), mas significantemente menos efetiva (5\%) que a irrigação dinâmica manual. Quanto à profundidade de inserção da agulha, a irrigação foi mais efetiva (7\%) quando esta foi realizada mais próxima do comprimento de trabalho.

Sabet e Lufty (2008) avaliaram e compararam in vitro, por meio de M.E.V., Microscópio Estereoscópico e Espectroscopia de energia dispersiva respectivamente, a limpeza, rugosidade e a presença de restos de NiTi nas paredes dos canais radiculares de 40 dentes uniradiculares de estoque instrumentados pelos sistemas ProTaper $^{\circledR}$ e $N T R^{\circledR}$. Os autores concluíram que ambos os sistemas apresentaram bons resultados na remoção de débris e smear layer das paredes dos canais radiculares nos terços cervicais e médios, mas foram ineficazes nos terços apicais. Paredes mais suaves foram obtidas pela instrumentação com o sistema ProTaper ${ }^{\circledR}$ e que foram observados restos de NiTi nas paredes dos canais radiculares na utilização de ambos os sistemas.

Desai e Himel (2009) avaliaram a segurança de diversos sistemas de irrigação intracanal pela mensuração da extrusão apical do irrigante. Para tanto, vinte e dois dentes uniradiculares humanos de estoque foram utilizados e instrumentados utilizando os sistemas de irrigação EndoVac $^{\circledR}$, com micro e macro cânula, EndoActivator ${ }^{\circledR}$, irrigação convencional com agulhas 
seringa, irrigação ultrassônica e RinsEndo ${ }^{\circledR}$. Os resultados mostraram que o sistema EndoVac ${ }^{\circledR}$ não apresentou extrusão apical, tanto com a micro, quanto com a macro cânula, e o sistema EndoActivator ${ }^{\circledR}$ extruiu significantemente menos que os demais sistemas testados quando a irrigação foi realizada na câmara pulpar e no interior dos canais radiculares.

GU et al. (2009) realizaram uma extensa revisão sobre os mecanismos métodos e técnicas de irrigação contemporâneas utilizadas na Endodontia e promoveram uma discussão sobre sua eficácia no desbridamento e na remoção da smear layer dos canais radiculares. Os autores concluíram que o entendimento desse assunto é crucial para os cientistas clínicos aperfeiçoarem o desenho e a utilização de futuras gerações de sistemas de agitação da solução irrigante apresentando mais segurança e melhores resultados na limpeza dos canais radiculares.

Williamson, Sandor e Justman (2009) compararam, por meio da microscopia eletrônica de varredura, a limpeza promovida por três diferentes sistemas de instrumentação rotatória mecanizada: ProTaper Universal ${ }^{\circledR}$ (Dentsply, USA) com conicidades variadas, ProFile GT $^{\circledR}$ (Dentsply Maillefer, Suíça) Taper .04 e, EndoSequence ${ }^{\circledR}$ (Brasseler, USA) com a mesma conicidade do anterior até a lima \#40 pela técnica crown down. Foram utilizados 36 dentes molares inferiores divididos em 3 grupos, dos quais, 2 dentes de cada grupo não receberão instrumentação (controle). As amostras foram seccionadas no sentido longitudinal e posteriormente os terços médios das raízes foram analisadas com aumento de 500X. Os resultados demonstraram não haver diferença estatística significante entre os grupos testados na limpeza promovida nos canais radiculares.

Boutsioukis et al. (2010) avaliaram, por meio de um modelo dinâmico de fluido computadorizado (CFD), o efeito do tamanho do preparo apical no fluxo da solução irrigante no canal radicular durante a irrigação final com seringa e dois diferentes tipos de agulhas 
(agulha convencional com abertura lateral) inseridas em canais simulados a $3 \mathrm{~mm}$ aquém do forame com diâmetros equivalentes a instrumentos $25,35,45$ e 55 todos com conicidade .06 . Os autores concluíram que o tamanho do preparo apical influenciou na substituição da solução irrigante, tensão de cisalhamento na parede do canal e na pressão no forame apical. Afirmaram também que a raiz com diâmetro acima de 25 pareceu melhorar o desempenho da irrigação, e que um espaço adequado entre a agulha e a parede do canal radicular deve ser assegurado para permitir circulação eficaz do refluxo da solução.

Bronnec, Bouillaguet e Machtou (2010) avaliaram in vitro, por meio de radiografias periapicais tiradas entre cada procedimento, a penetração e renovação do liquido irrigante dos canais radiculares de 30 molares inferiores com curvaturas de moderada a severas associado à irrigação em um dispositivo específico para que as radiografias ficassem na mesma posição. As raízes mesio-linguais de cada dente foram instrumentadas pelo sistema ProTaper $^{\circledR}$ até a lima \#20 conicidade .07, e entre cada procedimento executado, era realizado irrigação, ou por irrigação passiva (convencional) por meio de seringa e agulhas de 27 gauges ou irrigação ativada com movimentos de entrada e saída do canal com lima \#08. A visualização da penetração do irrigante radiograficamente foi possível pela remoção da solução de diatrizoato de sódio (radiopaco) previamente à irrigação estudada. Os autores concluíram que o preparo dos canais aumentava tanto a penetração quanto a troca da solução dentro dos canais radiculares, cuja renovação total foi impossível com o sistema convencional e, que a recapitulação com lima tipo $\mathrm{K}$ após a irrigação aumenta a penetração do liquido no interior dos canais radiculares.

Brunson et al. (2010) avaliaram in vitro, por meio de um dispositivo personalizado de mensuração de pressão negativa, a influência do tamanho do preparo apical, assim como sua conicidade, no volume de irrigação no comprimento de trabalho em canais radiculares 
preparados e o tempo necessário para a sua realização. Os autores concluíram que o aumento apical tanto em diâmetro como em conicidade resultaram em um significante aumento no volume da solução irrigante. Afirmaram também que quando o canal foi alargado com instrumento \# 40 taper .04 a estrutura do dente foi preservada e o máximo de volume de irrigação no terço apical foi utilizado por meio do sistema de irrigação com pressão negativa.

Caron et al. (2010) examinaram in vitro, por meio de M.E.V, o efeito da irrigação final com diferentes formas e métodos de ativação na remoção da smear layer das raízes mesiais de 50 molares inferiores de estoque. Os dentes foram instrumentados previamente pelo sistema ProTaper $^{\circledR}$ e irrigação com solução de hipoclorito de sódio a 3\%, posteriormente foram divididos em dois grupos controle e quatro grupos experimentais para a irrigação final com hipoclorito de sódio a 3\% e EDTA a 17\%: convencional (seringa e agulha) sem agitação; convencional com ativação dinâmica manual da guta percha; ativação dinâmica automática com o sistema RinsEndo ${ }^{\circledR}$ e ativação sônica com EndoActivator ${ }^{\circledR}$. Os autores concluíram que o sistema convencional de irrigação com agitação do cone de guta percha e o sistema sônico EndoActivator $^{\circledR}$ apresentaram os melhores resultados na remoção da smear layer das paredes dos canais radiculares quando utilizados para irrigação final em comparação aos outros grupos testados.

Fornari et al. (2010) avaliaram in vitro, por meio histológico, a eficácia do aumento do diâmetro na limpeza do terço apical em canais curvos preparados pela instrumentação rotatória com limas Hero $642^{\circledR}$ nos diâmetros \#30/.02, 35/.04, 40/.02 e 45/.02. Posteriormente ao processamento histológico e leitura das lâminas, os resultados foram submetidos à análise estatística, os quais mostraram que nenhum alargamento preparou completamente todas as paredes dos canais radiculares. 
Hecker et al. (2010) investigaram, por meio de lupa estereoscópica, qual alargamento seria o mais efetivo no preparo de todas as paredes dos canais radiculares de 140 pré-molares inferiores e superiores. A secção transversal do terço apical em dois níveis de cada elemento dental foi analisada. Os autores concluíram que nos pré-molares superiores com duas raízes e pré-molares inferiores, o preparo deveria ser realizado com pelo menos seis instrumentos acima do instrumento apical inicial (IAI), e que nos pré-molares superiores com canal único, o preparo apical deveria ser de no mínimo oito instrumentos acima do IAI.

Kunert, et al. (2010) avaliaram in vitro, por meio de radiografias digitais tanto no sentido vestíbulo-lingual, quanto mésio-distal, a ocorrência de transporte apical gerado após a preparo dos canais mésio-vestibulares de 25 primeiros molares superiores com instrumentos ProTaper $^{\circledR}$ Universal F3 e F4 no comprimento total do dente. Os resultados mostraram um maior índice de transporte apical nas amostras preparadas com F4 em comparação ao outro grupo no sentido vestíbulo-lingual. Os autores concluíram que o instrumento F3 pode ser utilizado em canais curvos com cuidado, e que o instrumento F4 deveria ser evitado no preparo de canais curvos no terço apical.

Martos et al. (2010) determinaram in vitro, por meio de microscopia operatória com aumento de 20X, a forma, posição do ápice radicular e do forame principal nos dentes anteriores superiores e inferiores humanos. Um total de 845 dentes extraídos foram avaliados quanto à posição do ápice e do forame principal (no centro, vestibular, lingual, mesial ou distal), e forma (arredondado, assimétrico, semilunar e oval) e do ápice radicular (arredondado, plano, em chanfro ou elíptico). As médias dos resultados foram calculadas, e os dentes foram divididos em grupos de incisivos, caninos, pré-molares e molares. Os autores concluíram que a maioria das formas encontradas nos dentes superiores e inferiores tanto do ápice radicular, quanto do forame principal era arredondada seguida da forma oval, e que a 
maior prevalência da localização do ápice radicular e forame principal foi ao centro da raiz, seguido pela posição distal.

Metzger et al. (2010) introduziram um novo conceito no preparo dos canais radiculares e o compararam aos instrumentos rotatórios de NiTi existentes. Eles apresentaram um instrumento cilíndrico oco em forma de rede confeccionado a partir de uma liga de NiTi que se auto ajusta nas paredes dos canais e, que por meio de movimentos de entrada e saída com vibração e irrigação constante pela sua parte oca, remove dentina das paredes dos canais radiculares. $\mathrm{O}$ instrumento é acionado mecanicamente por uma peça de mão, e foi conhecido como $S A F^{\circledR}$ (Self-Adjusting File ${ }^{\circledR}$ ). Este foi concebido na intenção de sanar as dificuldades encontradas pelos sistemas de preparo rotatórios dos canais radiculares, tanto por causa da grande variedade e dificuldades anatômicas encontradas nos canais radiculares como istmos e áreas de difícil acesso nos casos de conformação oval e achatamento de raiz, quanto nas curvaturas e manutenção do leito original resultando em canais mais limpos e preparos mais seguros, uma vez que não ocorre fratura. Os autores concluíram que a $S A F^{\circledR}$ representa um novo passo no desenvolvimento de lima endodôntica que pode superar muitas das deficiências dos atuais sistemas rotatorios de Niti.

Rödig et al. (2010) compararam in vitro, por meio de visualização com Microscópio Operatório, a eficácia da remoção de débris em canaletas produzidas artificialmente nas paredes de 30 dentes pré-molares de estoque. As amostras foram instrumentadas previamente pelo sistema FlexMaster $^{\circledR}$ até a lima 30/.02 (grupo I), 40/.02 (grupo II) e 50/.02 (grupo III), posteriormente foram clivadas longituninalmente para a confecção das canaletas, as quais foram preenchidas com débris anteriormente ao processo de irrigação com os sistemas convencional (seringa e agulha), RinsEndo ${ }^{\circledR}$ e irrigação passiva ultrasônica. Os autores 
concluíram que a irrigação passiva ultrasônica foi mais efetiva em comparação com os outros grupos testados.

Siqueira Jr et al. (2010) compararam in vitro, a capacidade de eliminação de Enterococus faecalis dos canais radiculares ovais de 44 dentes instrumentados pelo sistema rotatório BioRace ${ }^{\circledR}$ até a lima \#40/. 04 com irrigação convencional e agulhas NaviTip ${ }^{\circledR}$ e um novo sistema de preparo chamado Safe Adjusting file ${ }^{\circledR}\left(S A F^{\circledR}\right)$, e a possibilidade da modificação da técnica para alcançar bactérias alojadas em recessos nos canais radiculares. Os autores concluíram que o sistema $S A F^{\circledR}$ foi substancialmente mais efetivo que o sistema rotatório com limas de NiTi e irrigação convencional na desinfecção dos canais radiculares, e que uma modificação na técnica pode ser necessária para alcançar regiões de difícil acesso.

Singla et al (2010) avaliaram in vitro, o efeito de várias técnicas com instrumentos de diferentes conicidades na limpeza e na resistência á fratura vertical de raiz pós preparo de 50 pré-molares inferiores que tiveram inoculado em seus canais radiculares Enterococus faecalis. As amostras foram divididas em cinco grupos e instrumentadas de acordo como se segue: grupo I, preparo dos canais radiculares com limas de aço inox manual até a lima \#40 taper .02, grupo II, instrumentação rotatória mecanizada com sistema Profile ${ }^{\circledR}$ até a lima \#40 taper .04, grupo III, preparo conforme grupo II até o instrumento \#40 taper .06, grupo IV, instrumentação rotatória mecanizada com sistema ProTaper $^{\circledR}$ até a lima F4, grupo V (controle) dividido em: (Va) canais contaminados pela bactéria e sem instrumentação e (Vb) sem bactéria e nem instrumentação dos canais radiculares. A limpeza foi calculada pela diminuição do número de bactérias e a resistência á força vertical de fratura pela maquina Instron $^{\circledR}$ por meio da pressão de espaçadores digitais. Os melhores resultados foram obtidos pelo grupo que instrumentou os canais radiculares até a lima \#40 taper .06 apresentando alto 
índice de desbridamento sem diminuição significante da resistência á fratura com forças verticais nas raízes.

Vivan et al. (2010) compararam in vitro, por meio de M.E.V, a eficácia na remoção de débris e smear layer das paredes dos canais radiculares de 20 pré-molares inferiores pelos sistemas de irrigação RinsEndo ${ }^{\circledR}$ e convencional (seringa e agulha). Os autores concluíram que não houve diferença estatística significante na habilidade de limpeza entre os grupos testados.

Dai et al. (2011) avaliaram in vitro, por meio de microscopia eletrônica de varredura, a habilidade de duas versões de uma substância irrigante experimental antimicrobiana chamada Q.mix, água destilada, EDTA a $17 \%$ e BioPure $M T D A^{\circledR}$ na irrigação final das paredes dos canais radiculares, quanto à remoção da smear layer e débris de 50 dentes uniradiculares humanos de estoque. Os autores concluíram que tanto as versões da solução experimental (Qmix), quanto à solução de EDTA a 17\% foram eficazes como irrigantes finais na remoção da camada de smear das paredes dos canais radiculares previamente irrigados com solução de hipoclorito de sódio a 5,25\%.

\section{2) Evolução do Tomógrafo Computadorizado na Odontologia}

Tachibana e Matsumoto (1990) utilizaram in vivo pela primeira vez o tomógrafo computadorizado como ferramenta de diagnóstico em Endodontia. Os autores consideraram como vantagens a visualização de estruturas não identificadas pela radiografia convencional, bem como a possibilidade de reconstrução tridimensional dos canais radiculares e dentes. Contudo, consideraram como desvantagens, a alta dose de radiação, o tempo de escaneamento, o custo e o tamanho elevado do aparelho, além da resolução inadequada para detalhamento diagnóstico de pequenas áreas. 
Gambil; Alder; Del Rio (1996) avaliaram in vitro, por meio de tomografia computadorizada, o transporte apical de 36 dentes uniradiculares. Os canais radiculares foram preparados manualmente com limas de níquel titânio (NiTi) ou de aço inox, posteriormente foram divididos em três grupos e, submetidos à tomografia computadorizada antes e após o preparo biomecânico. No grupo I, os canais foram instrumentados com limas de aço inox Kflex com $1 / 4$ de volta/tração. No grupo II, os canais foram instrumentados com limas manuais de NiTi $\left(\right.$ Mity $\left.{ }^{\circledR}\right)$ com a mesma técnica do grupo I, no grupo III, os canais foram preparados com limas manuais de NiTi pela técnica de alargamento. Os autores concluíram que os instrumentos de NiTi causaram significantemente menor transporte apical que os instrumentos de aço inox $(\mathrm{p}<0,05)$, removeram significantemente menor volume de dentina $(\mathrm{p}<0,05)$, necessitaram menor tempo de preparo biomecânico $(\mathrm{p}<0,05)$ e produziram preparos mais centralizados. Os autores salientaram que o tomógrafo computadorizado é um método passível de reprodução e não invasivo.

Dowker et al. (1997) utilizaram a microtomografia computadorizada com resolução isotrópica de $0,40 \mu \mathrm{m}$, para avaliação do preparo endodôntico em três dentes extraídos. A reconstrução tridimensional foi feita com topogramas obtidos a partir de cortes axiais. Os autores concluíram que apesar de ótima ferramenta para ensino e pesquisa em Endodontia, ela não poderia ser utilizada em pacientes devido aos altos níveis de radiação necessárias para obtenção das imagens.

Peters et al. (2000) avaliaram in vitro, por meio de Microtomógrafo Computadorizado de alta resolução ( $\mu \mathrm{CT}$, resolução cúbica de $36 \mu \mathrm{m})$, o potencial e a precisão da técnica tridimensional não destrutiva para detalhamento da configuração e do diâmetro dos canais radiculares de 12 molares superiores. Os autores concluíram que a geometria dos canais foi 
precisamente calculada por esta inovadora técnica, podendo servir como base para futuros estudos de anatomia interna dos canais radiculares.

Rhodes et al. (2000) compararam in vitro, por meio de microtomografia computadorizada, o preparo dos canais radiculares realizado pela técnica de instrumentação manual e rotatória mecanizada com limas de NiTi. As áreas a 2; 3; 4,5; 6 e 7,5 aquém do ápice foram mensuradas e o transporte analisado. Os autores concluíram que não houve diferença estatística significante entre as técnicas comparadas, as quais produziram preparos centralizados.

Bergmans et al. (2001) apresentaram uma metodologia objetiva para avaliação quantitativa da instrumentação dos canais radiculares por meio de tomografia microcomputadorizada (desktop x-ray microCT-scanner ${ }^{\circledR}$ ) juntamente com o desenvolvimento de um software baseado na construção de um modelo matemático antes e após a instrumentação canais radiculares de molares inferiores para a visualização de transporte apical e centralização de preparo. Os autores concluíram que esta metodologia é uma maneira nova e objetiva para a avaliação quantitativa da instrumentação dos canais.

Gluskin, Brown e Buchanan (2001) compararam, por meio de tomografia computadorizada, o efeito do preparo com limas manuais de aço inox Flexofiles $^{\circledR}$ associadas às brocas de Gates-Glidden ou instrumentos rotatórios GT Rotary files ${ }^{\circledR}$ pela técnica crown down o transporte dos canais radiculares e espessura das paredes remanescente realizados por estudantes de graduação. Os autores concluíram que sob as condições deste estudo, os estudantes foram capazes de preparar canais radiculares curvos com limas rotatórias de NiTi promovendo baixo índice de transporte e grande conservação da estrutura dental e em menor tempo que a técnica manual com limas de aço inox. 
Peters et al. (2001) compararam in vitro, por meio da reconstrução tridimensional utilizando o Microtomógrafo Computadorizado (MCT), o efeito de quatro sistemas endodônticos de preparo de canais radiculares de molares superiores analisando o volume e a área de superfície. Os espécimes foram escaneados antes e após o preparo dos canais radiculares com limas manuais de NiTi, e mecanizadas Lightspeed ${ }^{\circledR}$, ProFile $^{\circledR}$ conicidade .04 e $G T^{\circledR}$. Foram calculados o volume de dentina removida, a retificação dos canais, a porção de área não tocada e o transporte do canal utilizando um programa especialmente desenvolvido para este fim. Os autores concluíram que dentro das limitações do sistema de Microtomografia Computadorizada, não foi encontrada diferença estatística entre os sistemas testados, por outro lado, variações de anatomia dos canais foram demonstradas, necessitando de mais estudos com tecnologia de reconstrução tridimensional para a compreensão dos aspectos biomecânicos do preparo do canal radicular.

Peters et al. (2001) estudaram in vitro, por meio da microtomografia computadorizada de alta resolução ( $\mu \mathrm{CT}$, resolução cúbica de $36 \mu \mathrm{m})$, as mudanças na geometria de 18 canais radiculares em seis molares superiores após seu preparo. Os canais foram preparados com limas tipo $\mathrm{K}$ pelas técnicas manual, Lightspeed ${ }^{\circledR}$ e ProFile ${ }^{\circledR}$ taper .04 pela técnica mecanizada. Os canais foram escaneados antes e após a instrumentação, e as mensurações das áreas e dos volumes calculados por um software personalizado. Os resultados mostraram que as variações anatômicas antes do preparo tiveram maior influência nas mudanças na geometria dos canais durante o preparo do que as técnicas propriamente ditas.

Peters et al. (2003a) avaliaram in vitro, por meio de Microtomógrafo Computadorizado, o desempenho dos instrumentos ProTaper $^{\circledR}$ de NiTi no preparo de canais radiculares de molares superiores com geometrias variadas. Os elementos foram escaneados para a análise do volume, área, espessura (diâmetro), transporte e superfície dos canais radiculares 
preparados, e divididos em canais estreitos e amplos, os quais tiveram seus volumes pré e póspreparo comparados. Os resultados mostraram que os canais radiculares foram preparados pelos instrumentos supracitados sem grandes erros, os quais se apresentaram mais eficientes nos grupos de canais estreitos.

Peters et al. (2003b) investigaram in vitro, por meio de Microtomógrafo Computadorizado o parâmetro físico dos instrumentos ProTaper $^{\circledR}$ durante o preparo de canais curvos de molares superiores. Os canais foram divididos em estreitos e amplos dependendo de seus volumes. Foram anotados os picos de torque e a força necessária juntamente com o número de voltas necessárias para o preparo dos canais radiculares. A análise do volume dos canais radiculares foi realizada, e com base nesses dados os resultados puderam ser comparados. Os autores concluíram que mesmo quando forças excessivas foram imprimidas em alguns casos que apresentavam patência apical, não ocorreram fraturas nos instrumentos, afirmaram também que houve uma correlação positiva entre a anatomia interna dos canais e os parâmetros físicos durante o preparo.

Eder et al. (2005) investigaram um novo método de diagnóstico aproximado de exame da configuração da raiz mesio vestibular de primeiros molares superiores. Assim sendo, 152 dentes humanos extraídos foram examinados comparando o resultado da tomografia computadorizada médica à histológica classificando-os segundo a classificação de Weine e Vertucci. Os resultados mostraram que a classificação observada pelo tomógrafo computadorizado foi idêntica ao resultado obtido pelo exame histológico, demonstrando a alta capacidade desse aparelho para visualização tanto da anatomia interna dos canais radiculares quanto o número de canais existentes em uma determinada raiz, podendo ser utilizado com segurança. 
Mennocci et al. (2005) investigaram in vitro, por meio da Microtomografia Computadorizada a prevalência de istmos nos $5 \mathrm{~mm}$ apicais das raízes mesiais de molares inferiores e sua morfologia. Os autores revelaram que os istmos foram prevalentes na maioria das raízes observadas, e que a prevalência destes nos três milímetros apicais foram maiores do que o esperado, podendo afetar de forma drástica o resultado do tratamento endodôntico, demonstrando de forma enfática a importância do conhecimento da anatomia interna dos canais radiculares.

Sponchiado et al. (2006) utilizaram in vivo, a Tomografia Computadorizada como ferramenta de estudo e diagnóstico para o tratamento endodôntico de um incisivo central superior com duas raízes e dois canais. Os autores relataram a importância do conhecimento da anatomia interna e externa dos dentes para o alcance do sucesso no diagnóstico e tratamento na terapêutica endodôntica, e para tanto, a metodologia utilizada se mostrou eficiente.

Limongi et al. (2007) compararam in vitro, por meio de tomografia computadorizada Multi Slice (helicoidal), a quantidade de dentina removida das paredes dos canais radiculares pela técnica manual com limas de aço-inoxidável e mecanizada por limas da níquel titânio. Foram utilizados quarenta dentes incisivos inferiores humanos, os quais foram divididos em dois grupos tendo as espessuras das paredes de seus canais radiculares analisadas antes e após o preparo. Os autores concluíram que quanto à remoção da dentina nas paredes dos canais radiculares durante o preparo, nenhuma das técnicas foi considerada mais efetiva que a outra.

Loizides et al. (2007) compararam in vitro, por meio de Microtomógrafo Computadorizado, o efeito de dois sistemas rotatórios mecanizados no preparo de 22 raízes mesiais de primeiros molares inferiores. Foram utilizados os sistemas Hero ${ }^{\circledR}$ (ApicalShaper $^{\circledR}$ e EndoFlare $^{\circledR}$ ) e ProTaper $^{\circledR}$, as amostras foram escaneadas antes e após o preparo e as 
diferenças na instrumentação dos canais, área transversal, perímetro, assim como a extensão de transporte foram calculadas. Os autores concluíram que ambos os sistemas prepararam os canais radiculares com rapidez e eficiência, contudo, o sistema ProTaper ${ }^{\circledR}$ apresentou uma ligeira tendência ao transporte apical.

Cheung e Cheung (2008) avaliaram por meio da tomografia computadorizada a segurança e eficácia da instrumentação de 43 segundos molares inferiores portadores de configuração em forma de "c" ( $c$-shape) dos canais radiculares com uma combinação de limas ProFile $^{\circledR}$ e Hero ${ }^{\circledR}$, mensurando as espessuras das paredes antes e após o preparo. Os resultados mostraram que somente algumas regiões dos canais foram preparadas pelos instrumentos demonstrando a ineficácia da instrumentação desses canais por este método. Os autores também afirmaram que deveria ser utilizado a irrigação ultrassônica como coadjuvante à instrumentação e que o alargamento dos canais com limas acima da \#30/. 06 não é recomendado.

Dall'agnol, Hartmann e Barletta (2008) avaliaram in vitro, por meio de tomografia computadorizada, a eficiência de diferentes técnicas de remoção de material obturador de sessenta raízes mesiais de molares inferiores, dentre elas, remoção por instrumentação manual com limas tipo K, instrumentação oscilatória mecanizada com limas tipo K e, instrumentação rotatória mecanizada com limas ProTaper $^{\circledR}$. Os dentes foram instrumentados e obturados pela técnica de termoplastificação da guta-percha, após seis meses os espécimes foram retratados. Foi realizado exame tomográfico computadorizado antes e após o retratamento dos canais radiculares. Os resultados demonstraram que nenhuma técnica foi completamente efetiva na remoção do material obturador do interior dos canais radiculares.

Estrela et al. (2008a) avaliaram a precisão dos métodos de imagem para detecção de periodontites apicais em 888 pacientes pelo exame radiográfico panorâmico, periapical e 
tomografia computadorizada cone beam (CBCT). Os resultados mostraram que as periodontites apicais foram significantemente mais evidentes quando na utilização do CBCT, em contra partida, os métodos convencionais apenas conseguiam evidenciá-las, quando essas se apresentavam em um estado mais avançado.

Estrela et al. (2008b) avaliaram in vivo um novo índice periapical baseado na Tomografia Computadorizada cone beam (CBCT) para a identificação das periodontites apicais de 596 pacientes e 1014 imagens, este índice foi desenvolvido com base em critérios estabelecidos pela mensuração correspondente à radiolucência apical interpretada pelo Tomógrafo. As periodontites apicais foram identificadas em 39,5\% pelo método radiográfico e 60,9\% pelo método CBCT. Os autores concluíram que o CBCT mostrou-se um acurado método de diagnóstico aumentando a confiabilidade dos estudos epidemiológicos, especialmente com relação às periodontites apicais em sua presença e severidade.

Grande et al. (2008) mensuraram in vitro, por meio da análise microtomográfica computadorizada, o diâmetro dos canais, da raiz, proporção do diâmetro dos canais, média das conicidade dos canais radiculares em cada região, e espessura das paredes em diferentes níveis em 30 pré-molares portadores de canais longos e ovais. Os resultados mostraram que o diâmetro no sentido vestíbulo-lingual era maior que no mésio-distal, e que aumentavam no sentido da coroa, tanto dos canais, quanto das raízes, a espessura das paredes vestibulares e linguais eram maiores que as proximais, que o diâmetro a $1 \mathrm{~mm}$ do ápice era maios que 0.30 $\mathrm{mm}$ nos canais mais estreitos e maior que $0.40 \mathrm{~mm}$ nos mais largos, e que a conicidade dos canais no sentido vestíbulo lingual era maior que no sentido mesio-distal. Os autores concluíram que a anatomia oval era frequente na maioria das regiões apicais dos canais radiculares, e a alta correlação da forma do canal radicular e raiz. 
Hammad, Qualtrough e Silikas (2008) avaliaram por meio da microtomografia Computadorizada $\left(\right.$ SkyScan ${ }^{\circledR}$ 1072, Bélgica) a eficácia do retratamento endodôntico de 80 raízes uni radiculares pelo instrumentação manual ou rotatória mecanizada pelos instrumentos ProTaper $^{\circledR}$ para retratamento. A análise tomográfica foi realizada antes e após o retratamento dos canais radiculares de modo que o volume da obturação antes do retratamento fosse dividida pelo volume remanescente do material obturador pós preparo. Os autores concluíram que a metodologia empregada de análise foi efetiva e que nenhum dos métodos conseguiu remover na totalidade o material obturador dos canais radiculares.

Low et al. (2008) compararam a radiografia periapical e a tomografia computadorizada cone beam na análise de dentes posteriores superiores indicados para possível realização de cirurgia periapical. As imagens foram analisadas por radiologistas e endodontistas para se chegar a um consenso na interpretação dos achados radiológicos. Um total de 156 raízes foram analisadas e seus resultados demonstraram que a tomografia computadorizada detectou mais lesões em comparação ao método radiográfico o qual apresentou também dificuldade de análise nas raízes próximas ao soalho do seio maxilar assim como nos segundos molares. Os autores concluíram que o método tomográfico apresentou-se mais sensível, uma vez que detectou com mais segurança as lesões existentes nos ápices radiculares, assim como apresentou possibilidade mais concretas de mensuração dessas.

Mahran e Aboel-Fotouh (2008) compararam, por meio do tomógrafo computadorizado Multislice (helicoidal) o efeito de 3 sistemas de preparo dos canais radiculares em 45 canais mesio-vestibulares de molares inferiores na espessura remanescente de dentina no terço cervical e a quantidade de dentina removida durante o preparo com brocas de Gates-Glidden e limas manuais Flex- $R^{\circledR}$; ProTaper $^{\circledR}$, Hero Shaper ${ }^{\circledR}$. A aquisição de imagens foi realizada antes e após o preparo dos canais. Os autores concluíram que a tomografia computadorizada 
se mostrou capaz para a análise volumétrica 3D dos canais radiculares, demonstrando que o sistema ProTaper ${ }^{\circledR}$ removeu menor quantidade significante de dentina cervical na parede distal (zona de perigo) que os outros grupos testados, apresentando também os melhores resultados na remoção total de dentina entre os grupos.

Reuben, Velmurugan e Kandaswamy (2008) Avaliaram in vitro, por meio de Tomógrafo Computadorizado helicoidal, a morfologia de 125 primeiros molares inferiores da população indígena analisando o número de canais, distância da fissura central e o teto da câmara pulpar, entre o teto e o soalho da câmara, soalho e furca e, relação da junção cemento/esmalte e o teto da câmara pulpar. Os autores concluíram que a metodologia empregada para análise da anatomia interna e externa dos dentes era possível, demonstrando como resultado, que na maioria dos dentes (84\%), apenas três canais radiculares foram encontrados, e que a junção cemento/esmalte coincidia com o teto da câmara pulpar.

Shen e Haapsalo (2008) avaliaram, por meio de Tomógrafo Computadorizado o comportamento de corte de seis instrumentos de NiTi, dentre eles: ProFile ${ }^{\circledR}$, FlexMaster ${ }^{\circledR}$,

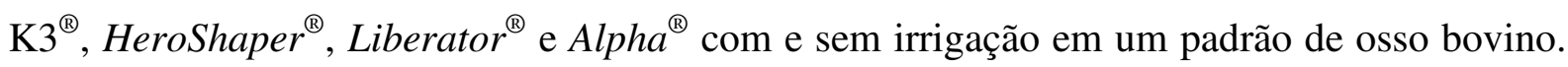
Após uma série de 100, 200, 300, 400 e 500 movimentos de vai e vem dos instrumentos no modelo, as canaletas foram escaneadas, posteriormente realizou-se a mensuração do volume de remoção do material e o máximo de penetração. Os resultados mostraram que a irrigação aumentou significantemente o poder de corte dos instrumentos testados exceto no Liberator $^{\circledR}$, houve uma correlação entre remoção de material e profundidade de penetração, a taxa de remoção do volume foi maior no grupo da $K 3^{\circledR}$ e Liberator $^{\circledR}$ sem irrigação e $\mathrm{K}_{3}{ }^{\circledR}$ e FlexMaster $^{\circledR}$ com irrigação, quanto à profundidade de corte, os melhores resultados foram obtidos nos grupos da $K_{3}{ }^{\circledR}$ e FlexMaster ${ }^{\circledR}$ tanto sem, quanto com irrigação. Os autores 
concluíram que o comportamento de corte dos instrumentos de NiTi dependem da configuração experimental, do desenho do instrumento e da condição de corte.

Yamashina et al. (2008) compararam o resultado dos valores e medidas dimensionais obtidos da região orofaríngea usando o Tomógrafo computadorizada cone beam (CBCT) e o Tomógrafo Computadorizado Multi-Detector (MDCT helicoidal). Foi utilizado um padrão com buracos de vários tamanhos com material com imagem radiográfica equivalente aos tecidos moles, o qual foi submetido aos dois tipos de aparelhos, assim como o ar, água e tecidos moles. As medidas dos buracos do padrão foram mensuradas pelos tomógrafos por meio das ferramentas do programa e comparados às medidas adquiridas pelos compassos clinicamente em loco. Os resultados mostraram que os valores de Hounsfield obtidos pelo CBCT foram completamente diferentes das medidas obtidas pelo método convencional MDCT. Os autores concluíram que o CBCT promoveu valores quantitativos limitados por cada pixel nos cortes de imagens na diferenciação do ar, água e tecidos moles.

Aggarwal et al. (2009) utilizaram in vivo, a Tomografia Computadorizada Multislice (helicoidal) como auxiliar no diagnóstico da anatomia interna de um primeiro molar superior, que ao realizar a pulpectomia e exploração dos canais radiculares, uma hemorragia no assoalho da câmara pulpar entre o canal distal e o palatino foi visualizada. Posteriormente à realização do exame tomográfico, foi constada a presença de um quinto canal na raiz palatina, o qual terminava em forame próprio. Os autores concluíram que esse exame foi de crucial importância para a identificação e visualização deste achado anatômico, que poderia prejudicar o resultado da terapêutica endodôntica.

Barato-Filho et al. (2009) investigaram a morfologia interna com observância no número de canais radiculares adicionais e suas localizações, número de forames e canais que não foram acessados por meio de três métodos, dentre eles: in vitro com auxílio de 
Microscópio Operatório, clínico com auxílio do microscópio Operatório e Tomográfico cone beam (CBCT). Os resultados in vitro mostraram frequência do quarto canal em $67,14 \%$ das amostras, desses, 92,85\% localizados na raiz mesial (17,85\% não puderam ser acessados), dos quais, $65,30 \%$ apresentavam apenas um forame, dentes com 7 canais $(0,72 \%)$. O grupo clínico mostrou 53; 0,35 e 0,35\% apresentaram 4, 5 e 6 canais respectivamente, $95 \%$ das raízes mesiais apresentavam o quarto canal e desses, 59\% exibiam apenas um único forame. Quanto ao CBCT, 1,85, 37 e 1,85\% apresentavam respectivamente 2, 4 e 5 canais radiculares. Os autores concluíram que o Microscópio Operatório e o CBCT apresentaram bons resultados na identificação e localização dos canais radiculares.

Chandra et al. (2009) utilizaram a tomografia computadorizada helicoidal em um caso clínico como auxiliar na identificação e tratamento do terceiro canal na raiz distal de um primeiro molar inferior. Os autores afirmaram que a utilização deste método provou ser uma eficiente ferramenta não invasiva para diagnosticar e estudar a anatomia interna dos canais radiculares, favorecendo a identificação e tratamento dos canais extras, o que segundo os autores, é a base para o sucesso endodôntico.

Fan et al. (2009) investigaram, por meio da Microtomografia Computadorizada, a exploração e negociação dos canais radiculares em c-shape de 44 segundos molares inferiores. Após a exploração dos canais com limas tipo K \#10 ou 15, com auxílio de microscópio operatório, as posições dos instrumentos e seus diâmetros foram escolhidos conforme a natureza dos canais. Posteriormente ao escaneamento e reconstrução das raízes com os instrumentos inseridos no seu interior, o número e a posição das limas foi analisado. Vários forames apresentaram apenas uma lima inserida no seu interior (42), 33 com dois, 8 forames tiveram três instrumentos inseridos no seu interior e 8 canais principais não foram identificados devido a bifurcações, calcificação e fusão de dentina. Os resultados desse novo 
método de análise das imagens demonstrou que a exploração cuidadosa dos canais associada à negociação dos mesmos, com os instrumentos, poderá promover a identificação da natureza do sistema endodôntico e o aumento do desbridamento nas anatomias complexas dos canais radiculares.

Gao et al. (2009) avaliaram por meio de um programa de aplicação utilizando um processador de imagens $M e V i s L a b^{\circledR}$ e uma plataforma de visualização 3D para reconstrução e estudo da anatomia da raiz e dos canais radiculares. Os autores escanearam com Microtomógrafo Computadorizado um primeiro molar superior de estoque antes e após o preparo com sistema ProTaper $^{\circledR}$. Após a reconstrução do dente, as dimensões do canal radicular, dentina e esmalte foram quantificados e os efeitos do preparo dos canais mensurados. Foi realizada também uma simulação de fratura de instrumento com a posterior remoção deste por meio do Kit Masseran de remoção de fragmentos, mensurando e quantificando os possíveis riscos deste procedimento para uma possível perfuração lateral da raiz. Os autores concluíram que este aplicativo ofereceu uma plataforma econômica e atendeu aos requisitos atuais de pesquisa endodôntica. Afirmaram também, que o uso desse software de alta qualidade e a troca de experiência resultante, poderia contribuir para melhorar a qualidade da investigação endodôntico com por meio da Microtomografia Computadorizada.

Liedke et al. (2009) avaliaram in vitro, a habilidade de diagnóstico do Tomógrafo Computadorizado cone beam (CBCT) com diferentes tamanhos de resolução de voxel na detecção de reabsorções radiculares externas simuladas nos canais radiculares de 59 dentes. Foram realizados três protocolos com variação da resolução dos voxels, 0,$4 ; 0,3$ e 0,2, um examinador sem acesso aos protocolos avaliou as imagens por meio do programa I-cat Vision $^{\circledR}$. Os autores concluíram que a utilização do CBCT para identificação de reabsorções 
externa nas raízes é um método confiável, e que o melhor protocolo associado ao desempenho de diagnóstico aliado a baixas doses de raios- $\mathrm{x}$ foi a de $0,3 \mathrm{~mm}$ de resolução de voxel.

Madarati, Qualtrough e Watts (2009) avaliaram in vitro, por meio de Microtomógrafo Computadorizado, o efeito da remoção de instrumentos fraturados no interior dos canais radiculares por meio de ultrassom para a estrutura dental. Foi realizada limpeza, pesagem e escaneamento de 53 dentes caninos de estoque para posterior reconstrução e mensuração de seus volumes. Os dentes foram instrumentados com o sistema ProTaper $^{\circledR}$ até a lima F5 no grupo controle, quanto aos demais dentes, a lima F5 foi fraturada em três regiões diferentes dividindo-os em três grupos: fratura no terço coronário, médio e apical. Posteriormente à remoção dos instrumentos, as amostras foram repesadas e escaneadas novamente. A diferença de volume e peso foi calculada. O maior aumento da variação do volume foi encontrado no grupo da remoção dos instrumentos do terço apical, seguido do médio e posteriormente o coronário, resultado esse, comprovado pela diferença de massa encontrada nas amostras. Os autores concluíram que o Microtomógrafo Computadorizado conseguiu determinar mudanças no volume radicular provenientes da remoção de instrumentos fraturados.

Paula-Silva et al. (2009) avaliaram a precisão na detecção de periodontite apical de dois métodos de diagnóstico de 83 dentes de cães, com ou sem tratamento endodôntico por meio de Tomografia Computadorizada cone beam ou radiografia periapical, utilizando a histologia como padrão ouro. As radiografias periapicais dos elementos, os topogramas das tomografias e as lâminas dos dentes após o preparo histológico foram avaliadas e seus valores calculadas quanto à precisão, sensibilidade e especificidade. Os autores concluíram que a metodologia de diagnóstico por meio do Tomógrafo Computadorizado cone beam apresentou-se mais preciso e sensível em comparação com o exame radiográfico periapical. 
Paqué et al. (2009) avaliaram, por meio da Microtomografia Computadorizada de alta resolução $(\mu \mathrm{CT})$, o efeito do preparo apical em sua geometria por diferentes sistemas, dentre eles preparo mecanizado com limas FlexMaster ${ }^{\circledR}$, GT-Rotary $^{\circledR}$, LigthSpeed $^{\circledR}$, Profile $^{\circledR}$, ProTaper $^{\circledR}$ e Limas tipo $\mathrm{K}$ de NiTi de preparo manual de molares superiores. Foi realizado preparo apical até a lima \#40 nos canais mesiais e distais e \#45 nos palatinos, com exceção dos sistemas $G T^{\circledR}$ (até lima 20) e ProTaper $^{\circledR}$ (25 nos mesiais e distais e 30 nos palatinos). As informações das mudanças de volume, estrutura e áreas não tratadas foram analisadas. Os resultados demonstraram que os volumes dos canais aumentaram após o preparo com diferenças significantes entre os sistemas. O sistema $G T^{\circledR}$ apresentou os menores aumentos e os maiores foram obtidos nos grupos da lima manual e do Profile ${ }^{\circledR}$ respectivamente. As áreas não tratadas foram mais visualizadas nos canais mesiais e palatinos que nos distais, e o sistema que apresentou o maior índice de áreas não tratadas foi o grupo das limas $G T^{\circledR}$ (em todos os tipos de canais), podendo desta forma, apresentar habilidade de desinfecção reduzida.

Paqué et al. (2009) avaliaram, por meio do Microtomógrafo Computadorizado de alta resolução, o acúmulo de débris e restos de tecido duro como resultado do preparo dos canais radiculares. Foram selecionados molares inferiores com canais mesiais não instrumentados e que apresentassem istmo entre eles baseados em seus pré-escaneamentos. As amostras foram instrumentadas pelo sistema ProTaper $^{\circledR}$ até a lima F3 sem o auxílio da irrigação nem antes e nem depois do preparo, posteriormente foram realizadas novo exame tomográfico das raízes. A média do volume do débris e do tecido duro remanescente após a instrumentação sem irrigação foi calculado em mais de $2 \mathrm{~mm}$ do sistema de canais mesiais multiplicando o volume do voxel com o número de voxels representado pelo material radiopaco adquirido. Os autores concluíram que o método utilizado parece adequado para a comparação quantitativa de diferentes tipos de instrumentação/irrigação sobre o acúmulo de débris pós preparo. 
Patél (2009) realizou extensa revisão de literatura sobre as aplicações e limitações do Tomógrafo Computadorizado cone beam (CBCT) na resolução dos problemas endodônticos e a partir dessa, afirmou que este tem sido designado para produzir informações em três dimensões sem distorções do esqueleto maxila, incluindo os dentes e tecidos adjacentes com significante baixa dosagem de radiação comparada com a tomografia médica convencional. Também salientou que doenças periapicais, reabsorções e fraturas podem ser detectadas e mensuradas, assim como o estudo da anatomia interna dental e da estrutura óssea podem ser avaliados e estudados.

Sberna et al. (2009) avaliaram in vitro, o uso do tomógrafo computadorizado quantitativo periférico (pQCT) na análise quantitativa e qualitativa da anatomia interna e estudo do alargamento do terço coronário do canal radicular de um primeiro pré-molar superior durante o preparo com limas S1-ProTaper ${ }^{\circledR}$ com e sem pincelamento das paredes. As imagens foram adquiridas antes e após o preparo e analisadas por um software de reconstrução 3D. Os autores concluíram que a utilização do tomógrafo computadorizado quantitativo periférico (pQCT) apresentou resultado positivo na análise morfológica e na mudança de volume dos canais radiculares antes e após o seu preparo, e que o software de reconstrução 3D baseado nas imagens adquiridas pelo pQCT necessita de mais aperfeiçoamento para sua aplicação na clínica como uma ferramenta de análise quantitativa e qualitativa dos procedimentos endodônticos.

Somma et al. (2009) avaliaram in vitro, por meio da Microtomografia Computadorizada a morfologia dos canais radiculares de raízes mesiais de primeiros molares superiores. Foi analisado o número e tipo dos canais radiculares, presença de istmo, canais acessórios, intercondutos, e números de forames apicais. O resultado comprovou a eficiência da Microtomografia Computadorizada no estudo da anatomia interna dos canais radiculares, 
evidenciando a grande complexidade dos canais das raízes mesiais dos primeiros molares superiores.

Bernardes, et al. (2010) compararam, por meio de tomografia computadorizada cone beam o aumento da área dos canais a 3, 5 e 7 milímetros aquém do ápice radicular de 22 raízes mesiais de molares inferiores após preparo com os sistemas EndoSequence ${ }^{\circledR} \mathrm{e}$ ProTaper $^{\circledR}$. As imagens foram adquiridas antes e após o preparo dos canais radiculares, e os resultados demonstraram que ambos os sistemas apresentaram um aumento significativo da área dos canais radiculares em todos os níveis de avaliação.

Gergi et al. (2010) analisaram, por meio de Tomógrafo Computadorizado helicoidal, o transporte e a habilidade de centralização de dois sistemas rotatórios de NiTi (Twisted files ${ }^{\circledR}$ e Panthfile-ProTaper $^{\circledR}$ ) e um manual de aço inox tipo $\mathrm{K}$ em 90 canais radiculares com curvatura acentuada e pequeno raio. As amostras foram divididas em três grupos e preparadas pelos devidos sistemas anteriormente citados, posteriormente foram realizadas análises do terço cervical, médio e apical das raízes. Os melhores resultados foram obtidos pelo grupo instrumentado pelo sistema Twisted Files ${ }^{\circledR}$ que além de demonstrar os menores índices de transporte, apresentaram também melhor capacidade de centralização do preparo, os piores resultados foram obtidos pelos instrumentos manuais de aço inox em ambos os quesitos.

La et al. (2010) utilizaram a Tomografia Computadorizada cone beam como auxiliar no diagnóstico da presença de um canal mesio-central na raiz mesial de um primeiro molar inferior. Foi realizada pulpectomia, exploração dos canais radiculares, preparo e seleção de cone principal para a obturação, mas ao modificar a angulação do exame radiográfico, foi constatada uma imagem de um possível canal mesio central adicional, o qual foi confirmado por meio do exame tomográfico que terminava em forame próprio. Os autores concluíram que esse exame se mostrou de suma importância para a identificação e visualização deste achado 
anatômico, tanto quanto no resultado do tratamento e visualização da obturação dos canais radiculares.

Paqué, Zehnder e Marending (2010) avaliaram in vitro o travamento das limas iniciais em 12 molares superiores portadores de 4 canais radiculares com forames separados por meio de Microtomografia Computadorizada $(\mu \mathrm{CT})$. Após a realização da odontometria com lima 06 por meio de localizador apical eletrônico para que não ocorresse manipulação do ápice, foi realizado preparo nos três quartos do comprimento anteriormente adquirido com instrumentação rotatória mecanizada com limas Profile ${ }^{\circledR}$ conicidade .04 com técnica crown down até a lima 20/.04 precedidas por brocas de Gates-Glidden (4-1), e irrigados por solução de Hipoclorito de sódio a $1 \%$. Foram inseridas limas manuais tipo K passivamente até $0,5 \mathrm{~mm}$ aquém do comprimento total do canal (comprimento de trabalho) até que o operador sentisse o travamento do instrumento, o qual posteriormente foi verificado eletronicamente e anotado como instrumento apical inicial (IAF). Foi realizado escaneamento por meio de $\mu \mathrm{CT}$ tanto das áreas transversais dos instrumentos e canais, quanto do maior e menor diâmetro do canal radicular a $1 \mathrm{~mm}$ da ponta do instrumento. Os Volumes dos $2 \mathrm{~mm}$ apicais dos instrumentos e as seções correspondentes do canal radicular foram calculados, e a lima selecionada foi avaliada. Os autores concluíram que a análise bi e tridimensional das raízes por meio do $\mu \mathrm{CT}$ revelaram mesmo que os instrumentos tivessem travado no ápice radicular, a sua adaptação seria pobre devido ao seu desenho não corresponder à forma anatômica dos canais radiculares dos molares superiores.

Sanfelice et al. (2010) avaliaram por meio do Tomógrafo Computadorizado cone beam I-CAT a quantidade de dentina removida da parede distal do canal mesial de 32 raízes de primeiros molares inferiores posteriormente ao preparo do terço cervical com: ProTaper $^{\circledR}$ (S1, SX e S2), $K_{3}{ }^{\circledR}(25 / .08$ e .10$)$, Gates-Glidden (n1 e 2$)$ ou LA Axxess ${ }^{\circledR}(20 / .06$ e $35 / .06)$. As 
imagens foram adquiridas antes e após o preparo com os devidos sistemas citados anteriormente. Os autores concluíram que todos os sistemas foram seguros no preparo cervical sem provocar danos á estrutura dental na parede distal (zona de perigo) dos canais mesiais de molares inferiores.

Mediante a realização dessa revisão de literatura, é lícito afirmar que os resultados tão almejados ainda estão longe de serem alcançados e desta forma há muito que investigar. 

Proposição 
O objetivo do presente trabalho consistiu em:

1. Determinar e comparar a área do canal radicular antes e após a instrumentação a $1 \mathrm{~mm}$ aquém do forame apical (CT) por meio clínico e tomográfico.

2. Avaliar, por meio de microscopia óptica, a limpeza da região apical dos canais radiculares em dentes com achatamento mésio-distal com observância dos seguintes itens:

2.1. Utilização da instrumentação rotatória mecanizada com três, quatro e cinco instrumentos acima do instrumento apical inicial (IAI),

2.2. Uso de duas técnicas de irrigação: a) convencional, por meio de seringa luer lock e agulha com abertura lateral e b) hidrodinâmica $\left(\right.$ RinsEndo $\left.^{\circledR}\right)$,

2.3. A ação dos instrumentos nas paredes dos canais radiculares. 

Material e Método 

Esta pesquisa foi desenvolvida após a aprovação do Comitê de Ética em Pesquisa da Faculdade de Odontologia de Ribeirão Preto da Universidade de São Paulo (Processo/2009.1.500.58.5, CAAE/0039.0.138.000-09) (Anexo).

\section{Delineamento Experimental}

\section{Seleção e preparo das amostras}

Para a realização deste experimento, utilizou-se quarenta e dois dentes incisivos inferiores humanos ex vivo com ápices completamente formados obtidos do banco de dentes da Faculdade de Odontologia de Ribeirão Preto da Universidade de São Paulo. Os fatores de exclusão utilizados foram os seguintes: a) dentes com dois canais radiculares, b) canais obturados, c) ápices incompletos, d) canais completamente calcificados, e) curvatura acentuada e f) tamanho inferior a 19 e superior a $21 \mathrm{~mm}$.

Para a obtenção dos dentes selecionados e a exclusão dos fatores indesejados, utilizouse tomadas radiográficas no sentido proximal e mensuração com paquímetro eletrônico digital Digitcal-SM $M^{\circledR}$ (Tesa, Suíça).

Os dentes selecionados foram mantidos em solução de timol a $0,1 \%$ à temperatura de $9^{\circ}$ centígrados até o momento da realização do experimento. Para a remoção dos traços da solução de timol, os espécimes foram lavados em água corrente por doze horas.

Após esta etapa confeccionou-se um dispositivo com o objetivo de fixar os dentes e se obter um padrão para a realização dos exames tomográficos iniciais e finais. 


\section{Dispositivo para a fixação dos dentes:}

Utilizou-se uma bandeja de aço inox $\left(\right.$ Fava $^{\circledR}$, Brasil) com dimensões de 11 X 20 X 1,5 centímetros no interior da qual se verteu silicona de condensação de macro modelos (Labor Mass $^{\circledR}$, RuthBras, Brasil) manipulada de acordo com as instruções do fabricante (Figura 1).

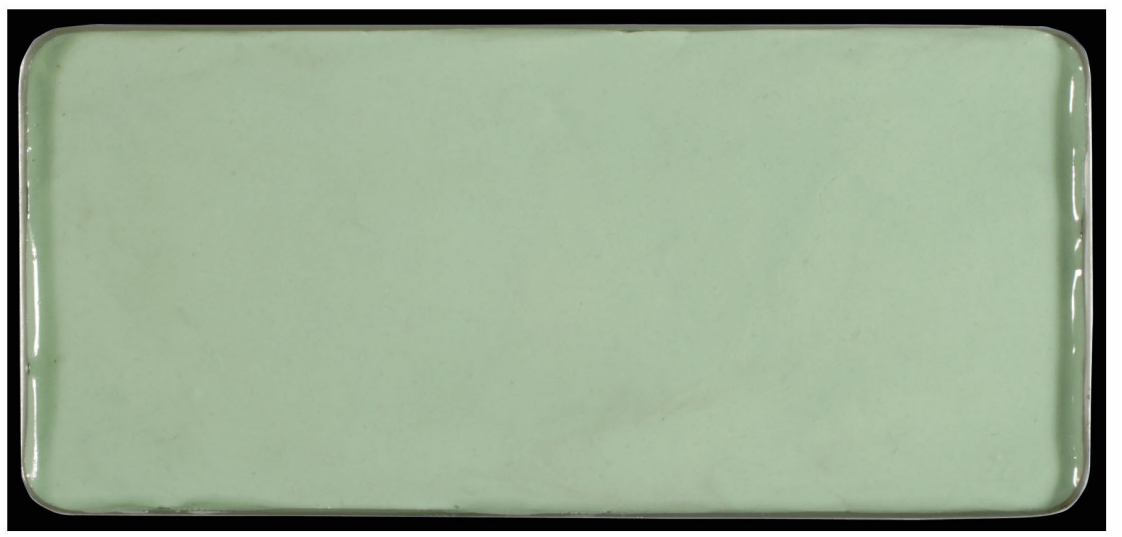

Figura 1. Bandeja de aço inox contendo silicona de condensação em seu interior.

A seguir os dentes foram introduzidos com as coroas no interior da silicona de modo que os espécimes fossem distribuídos em três fileiras com sete dentes cada, com seus eixos (vestíbulo-lingual e mésio-distal) no mesmo sentido (Figura 2).

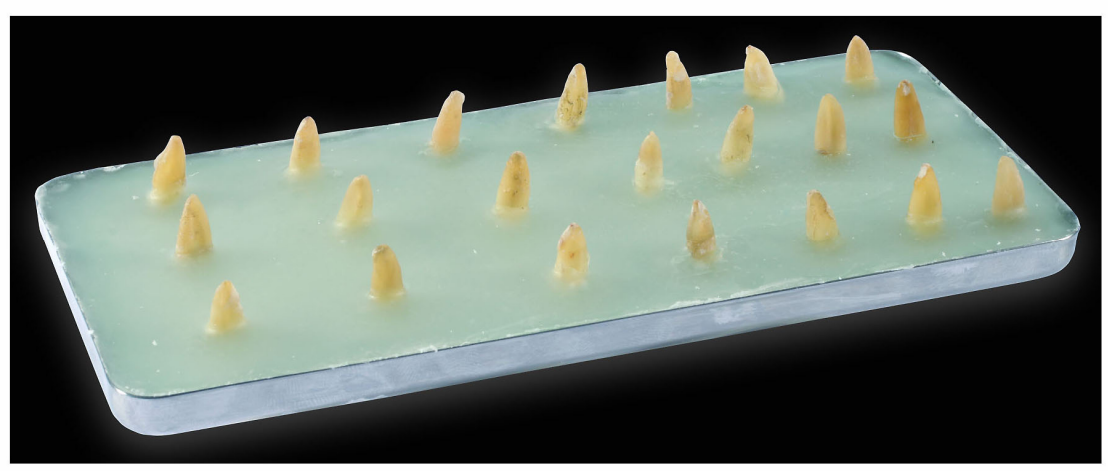

Figura 2. Disposição dos dentes inseridos na matriz de silicona. 
A seguir, resina acrílica incolor quimicamente ativada (Dencor, Clássico Artigos Odontológicos, São Paulo, Brasil), foi manipulada e vertida sobre a silicona de modo a fixar os dentes em seu limite amelo-cementário, formando uma placa de $4 \mathrm{~mm}$ de espessura (Figura 3).

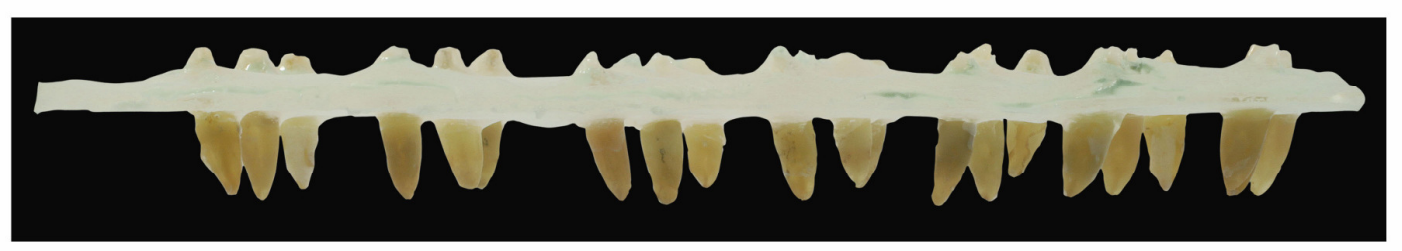

Figura 3. Disposição dos dentes na placa de acrílico.

Os espécimes foram distribuídos em duas placas de acrílico contendo 21 dentes cada de modo a formar três fileiras com sete dentes cada.

Com a finalidade de orientar os exames tomográficos e a identificação dos dentes, realizou-se perfurações com broca carbide esférica número 6 (FKG, Brasil) acionadas por micromotor e peça reta (Dabi Atlante, Brasil) na placa de acrílico com $3 \mathrm{~mm}$ de profundidade por $3 \mathrm{~mm}$ de diâmetro, sendo que três delas realizadas em uma face da placa, dispostas $2 \mathrm{em}$ uma lateral e a outra na outra extremidade e, duas na diagonal da outra face da placa. Essas perfurações foram preenchidas com guta percha de modo a propiciar imagens radiopacas (Figura 4).

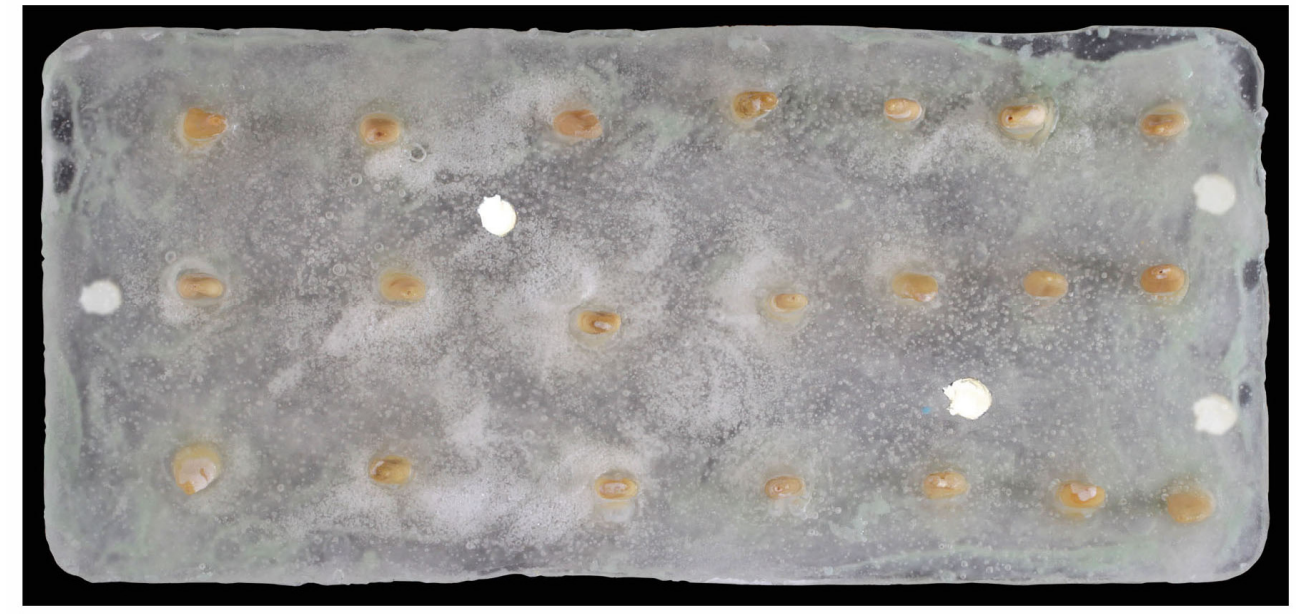

Figura 4. Placa de acrílico contendo 21 dentes e as cinco perfurações de orientação. 


\section{Exame Tomográfico}

Para a realização deste experimento, foi utilizado Tomógrafo Computadorizado I-CAT`s Cone Beam 3-D $D^{\circledR}$ (Dental Imaging System, Salt Lake City, USA) (Figura 5), específico para imagens do crânio. Este aparelho apresenta como características, tamanho compacto e tela de alta resolução capaz de produzir imagens tridimensionais. $\mathrm{O}$ aparelho trabalha com fonte de raios-X de alta frequência, potencial constante, $\mathrm{KVp}$ fixo do ânodo 120, 3-8 miliampere (modalidade de pulso); feixe de raios-X - cone ponto focal de $0,5 \mathrm{~mm}$; detector da imagem painel liso de silicone amorfo, 20 por $25 \mathrm{~cm}$; escala cinzenta - 14 bits; tamanho de voxel - 0,4 mm (típico), 0,125 mm (mínimo); aquisição da imagem - 360 de rotação; tempo de varredura sendo 20 segundos o tempo utilizado (opções 10, 20 e 40s); posição paciente - sentado; dimensões da varredura - $17 \mathrm{~cm}$ (diâmetro) por $13 \mathrm{~cm}$ (altura); campo de vista prolongado opcional - $16 \mathrm{~cm}$ (diâmetro) por $22 \mathrm{~cm}$ (altura); reconstrução preliminar - 1,5 minutos para varredura do padrão a 20 segundos; reconstrução secundária - tempo real.

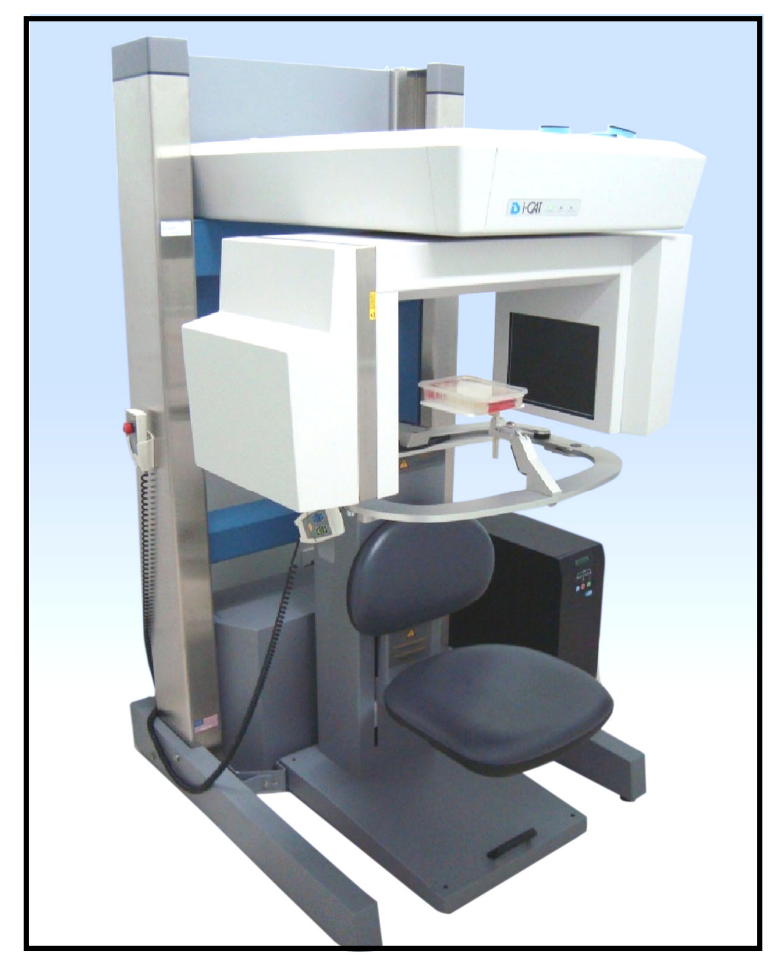

Figura 5. Tomógrafo Computadorizada I-CAT's Cone Beam 3-D ${ }^{\circledR}$. 
As imagens são adquiridas em formato shoran e posteriormente exportadas em Dicom (Digital Imaging and Comunication in Medicine), este acrônimo define o padrão tecnológico global permitindo que os dados sejam lidos por qualquer programa que contenha conversão DICOM, tornando os dados mais acessíveis sendo estes adquiridos por qualquer tipo de tomógrafos existentes (MOREIRA et al., 2009).

\section{Exame Tomográfico inicial}

Realizou-se o exame tomográfico inicial com cortes transversais (corte axial) das raízes, para a mensuração da área da região anatômica apical das amostras a $1 \mathrm{~mm}$ aquém do forame apical do elemento dental.

Esta medida foi mensurada em milímetros pela sequência de leitura no Tomógrafo Computadorizado e software de análise, as quais foram devidamente anotadas e os dentes identificados (Figura 6), para posterior comparação com o método clínico de seleção do instrumento apical inicial. Juntamente com essa mensuração foi criada uma linha de $5 \mathrm{~mm}$ para a posterior calibragem da "ferramenta de medida".

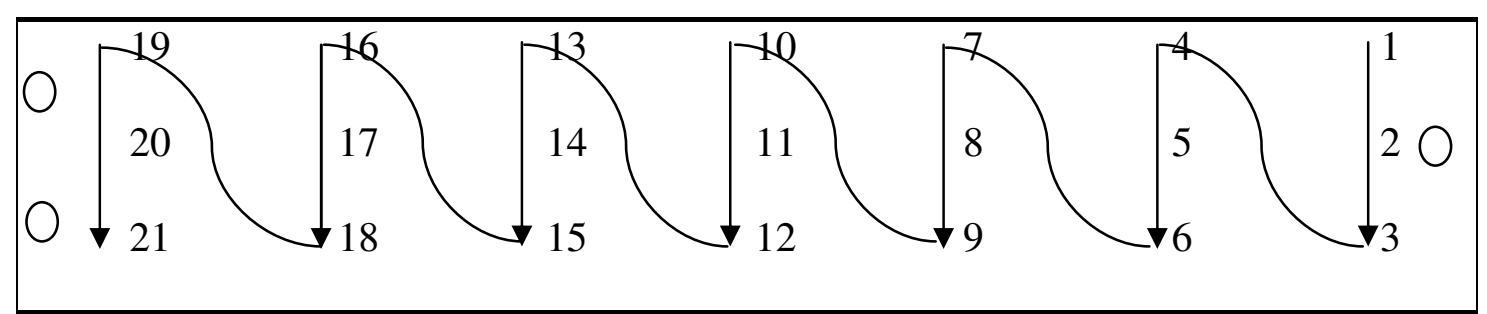

Figura 6. Esquema com a sequência dos dentes nos grupos (leitura no tomógrafo).

Para tanto, a placa de acrílico foi fixada em duas bases de cera utilidade de medida 2 por $5 \mathrm{~cm}$, de modo que os dentes ficassem imersos, mas suspensos em relação à base do recipiente de plástico incolor de 12 por $20 \mathrm{~cm}$ repleto de água (MOREIRA et al, 2009), para que as condições encontradas na boca fossem reproduzidas, uma vez que o aparelho é calibrado para visualização de estruturas que contenham água na sua composição. 
O recipiente contendo as amostras foi adaptado em uma mesa do tomógrafo própria para pesquisa (Figura 7), de modo que os espécimes ficassem posicionados corretamente no centro, onde os feixes de raios-X do tomógrafo pudessem alcançá-los na sua totalidade.

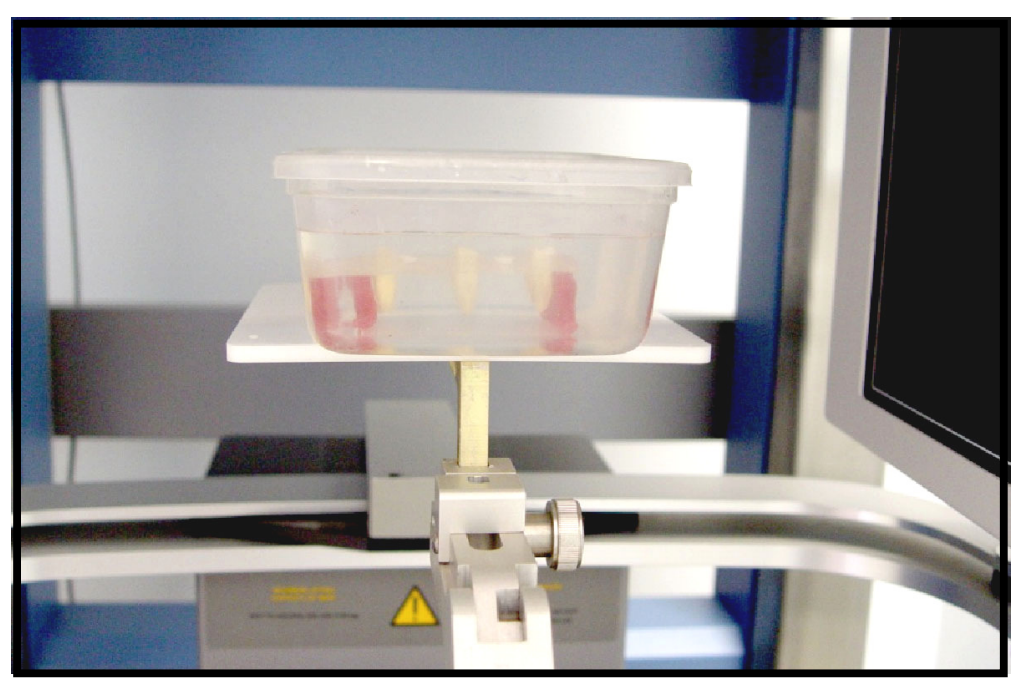

Figura 7. Detalhe da mesa própria para pesquisa adaptada na haste do Tomógrafo.

Após a realização do exame tomográfico inicial deu-se sequência no experimento com cirurgia de acesso, preparo cervical, seleção do instrumento apical inicial e preparo dos canais radiculares.

\section{Cirurgia de acesso e obtenção do comprimento de trabalho}

A cirurgia de acesso à câmara pulpar foi realizada na face palatina dos dentes com broca esférica carbide número 2 (Dentsply ${ }^{\circledR}$, Suíça) para o acesso e remoção do teto da câmara pulpar, posteriormente utilizou-se broca Endo- $Z^{\circledR}$ (Dentsply Maillefer ${ }^{\circledR}$, Ballaigues, Suíça) para dar divergência e alisamento às paredes da cirurgia de acesso (DE DEUS, 1992). Essas brocas foram acionadas por motor de alta rotação (Dabi Atlante, Brasil) com refrigeração. 
Com o auxílio de uma lima tipo K número \#10 (Dentsply-Maillefer ${ }^{\circledR}$, Ballaigues, Suíça), o canal radicular foi explorado em toda a sua extensão até que a lima coincidisse com o forame apical. A partir desse comprimento, foi removido desta medida $1 \mathrm{~mm}$, a fim de determinar o comprimento de trabalho (CT).

\section{Preparo biomecânico dos canais radiculares}

Uma vez obtido o CT, utilizou-se brocas LA Axxess ${ }^{\circledR}$ (SybronEndo, Glendora, Califórnia, USA) (20/.06 e 35/.06) (Figura 8) acionadas por contra ângulo sem redução e micro motor (Dabi Atlante, Ribeirão Preto, Brasil), a uma velocidade de 10.000 rpm, para a eliminação de interferências cervicais e médias (PÉCORA et al., 2005; BARROSO et al., 2005 e IBELLI et al., 2007).

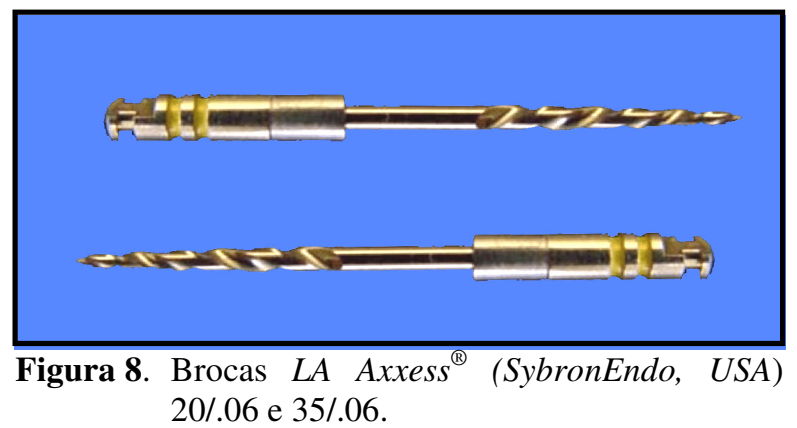

Posteriormente os canais radiculares foram irrigados por solução de hipoclorito de sódio a 2,5\%, para em seguida proceder-se com a seleção dos instrumentos apicais iniciais (IAI). Este procedimento foi realizado com auxílio de limas tipo $K$-Fle ${ }^{\circledR}$ de $25 \mathrm{~mm}$ de comprimento (Densell ${ }^{\circledR}$, Suécia) que melhor se adaptou ao diâmetro anatômico apical de cada dente, este instrumento foi anotado e a medida referente à área do diâmetro deste instrumento foi anotada para posterior comparação com a área obtida pelo método tomográfico anteriormente realizado (Apêndice). 
Findo esta etapa, os dentes foram separados em dois grupos contendo 21 dentes cada conforme o tipo de irrigação, grupo 1 irrigação convencional (seringa luer-lock e agulha) e grupo 2 irrigação hidrodinâmica (RinsEndo ${ }^{\circledR}$, Durr Dental, Alemanha).

Cada grupo foi dividido em três subgrupos de acordo com o número de instrumentos utilizados acima do IAI. Para o subgrupo 1 utilizou-se três instrumentos acima do IAI, no subgrupo 2 quatro instrumentos e no subgrupo 3, cinco instrumentos (Figura 9).

\begin{tabular}{|c|c|c|}
\hline Instrumento & \multicolumn{2}{|c|}{ TIPO DE IRRIGAÇÃO } \\
\hline & CONVENCIONAL & HIDRODINÂMICA \\
\hline $\begin{array}{l}\text { Subgrupo A } \\
3 \text { acima }\end{array}$ & 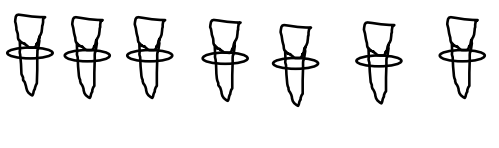 & 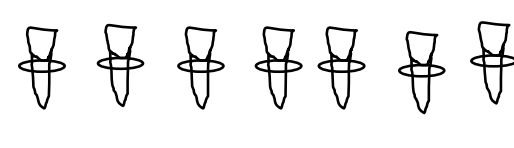 \\
\hline $\begin{array}{l}\text { Subgrupo B } \\
4 \text { acima }\end{array}$ & 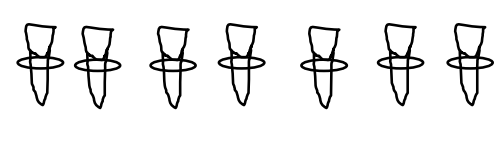 & 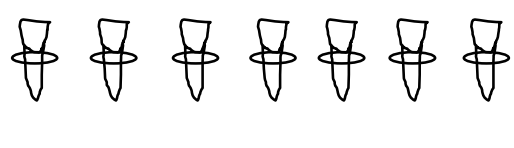 \\
\hline $\begin{array}{l}\text { Subgrupo C } \\
5 \text { acima }\end{array}$ & 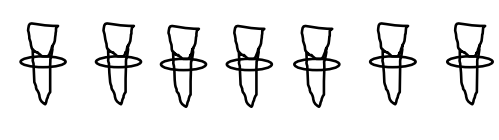 & 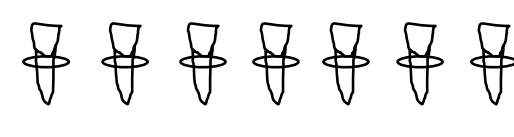 \\
\hline
\end{tabular}

Figura 9. Fluxograma do esquema de divisão de dentes em um grupo para o exame tomográfico.

A instrumentação dos canais radiculares, a seguir, foi realizada com a técnica Free Tip Preparation (PÉCORA et al. 2002) utilizando limas RT-Files ${ }^{\circledR}$ (Densell ${ }^{\circledR}$, Suécia) e Quantec series $^{\circledR}$ (SybronEndo, USA) (Figura 10) acionadas por motor elétrico EndoEst ${ }^{\circledR}\left(\right.$ Geosoft $^{\circledR}$, Rússia) (Figura 11) e velocidade constante de 250 rpm no comprimento de trabalho (CT). 


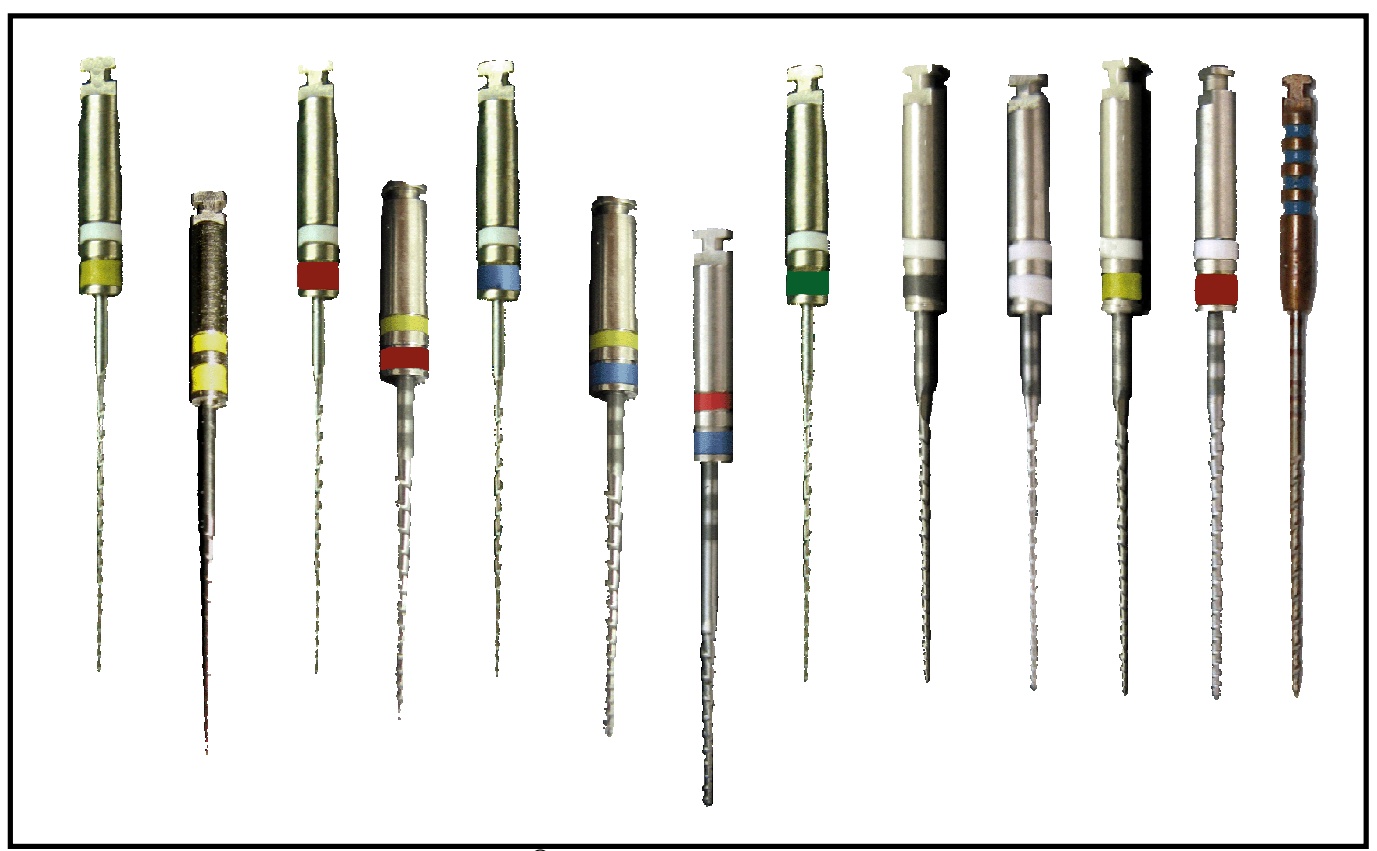

Figura 10. ${\text { Instrumentos } \text { RT-Files }^{\circledR} \text { (Densell, Suécia) e Quantec series }}^{\circledR}$ (SybronEndo, USA) utilizados no preparo dos dentes.

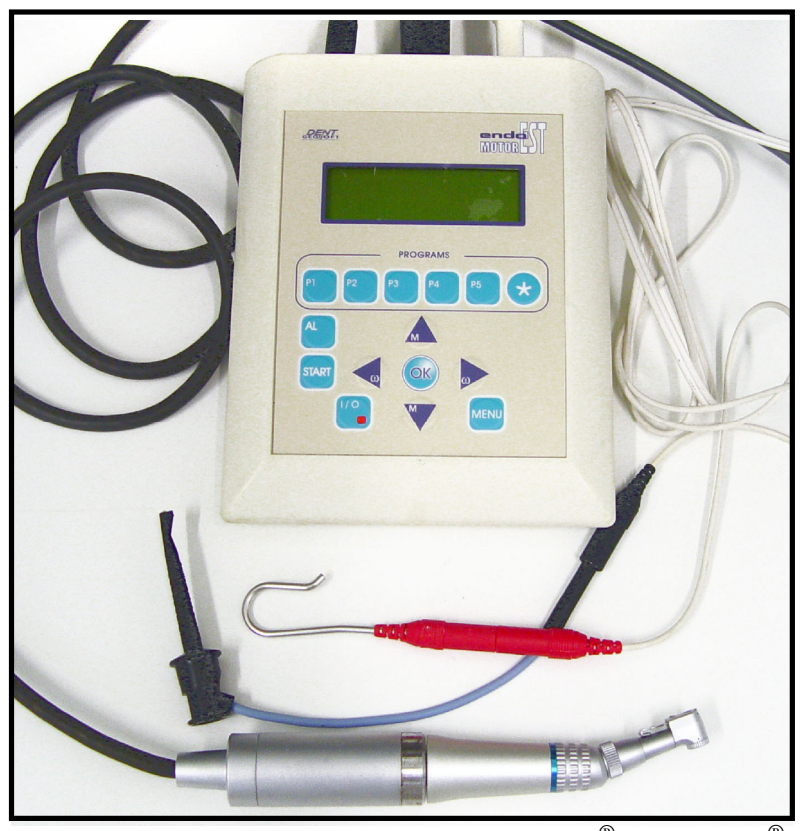

Figura 11. Motor elétrico EndoEst $t^{\circledR}\left(\right.$ Geosoft $^{\circledR}$, Rússia) utilizado no preparo dos canais radiculares.

O preparo foi iniciado pela lima correspondente ao diâmetro anatômico encontrado clinicamente na sequência: 20/.02; 20/.04; 25/.02; 25/.04; 30/.02; 30/.04; 30/.06; finalizando 
com três instrumentos acima do inicial; na primeira linha do padrão de acrílico, quatro acima na segunda e, cinco acima na terceira $(35,40,45,50,55 / .02)$ RT-Files $^{\circledR}$ (Densell ${ }^{\circledR}$, Suécia), e \#60/.02 Quantec series ${ }^{\circledR}$ (SybronEndo, USA).

\section{Técnica de irrigação}

A cada troca de instrumento o canal radicular foi irrigado com $2 \mathrm{ml}$ de solução de hipoclorito de sódio a 2,5\%, aviada e devidamente titulada no Laboratório de Pesquisa em Endodontia da FORP-USP, tendo como irrigação final $2 \mathrm{ml}$ desta mesma solução e por fim 2 ml de solução de EDTA $17 \%$.

Cada grupo teve como auxiliar químico do preparo dos canais radiculares a mesma solução, a diferença foi quanto à metodologia empregada para a realização do processo de irrigação-aspiração.

No grupo I foi utilizado irrigação convencional com seringa luer-lock de $5 \mathrm{ml}$ (Ultradent $^{\circledR}$ Products, USA) dotada com agulhas de irrigação Endo-Eze Irrigator Tips ${ }^{\circledR}$ (27

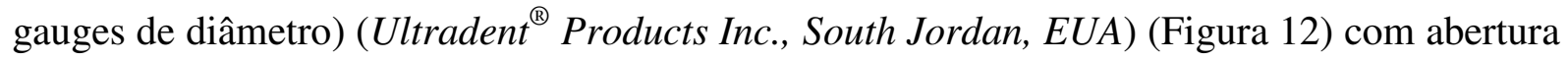
lateral e sucção convencional com bomba a vácuo (Ciclone ${ }^{\circledR}$, Dabi Atlant, Brasil), no grupo II, Irrigação hidrodinâmica automática sob pressão com dispositivo RinsEndo ${ }^{\circledR}$ (Dürr Dental, Alemanha) dotado de agulha (30 gauges de diâmetro) especial para irrigação com abertura lateral de $7 \mathrm{~mm}$ (RinsEndo, Dürr Dental, Alemanha) e dispositivo superior para o acoplamento de uma seringa repleta com a solução irrigante (Figura 13) e sucção semelhante ao grupo I.

O sistema é plugado ao micromotor (Dabi Atlant, Brasil), e acionado pneumaticamente. Este dispositivo apresenta uma cobertura plástica na agulha para evitar o refluxo da solução irrigante tanto para o paciente, quanto para o profissional, e uma abertura lateral para a introdução da cânula de sucção. 


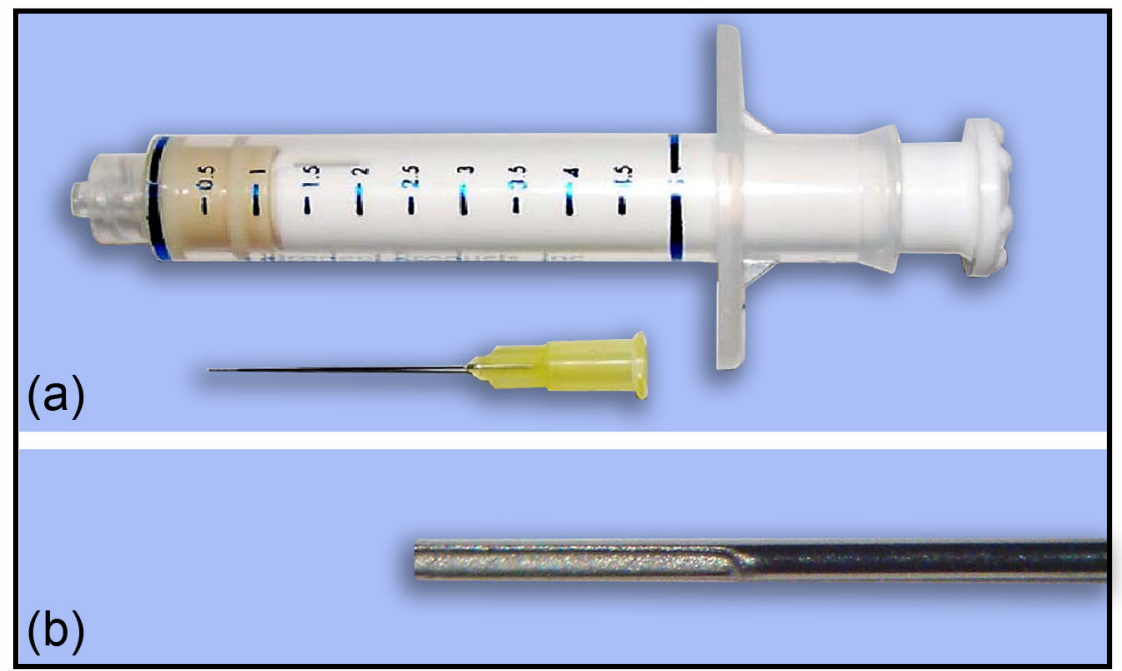

Figura 12. Seringa luer lock utilizada na irrigação convencional dos canais radiculares (a). Detalhe da ponta da agulha de irrigação EndoEze Irrigator Tips ${ }^{\circledR}$ com abertura lateral (b).

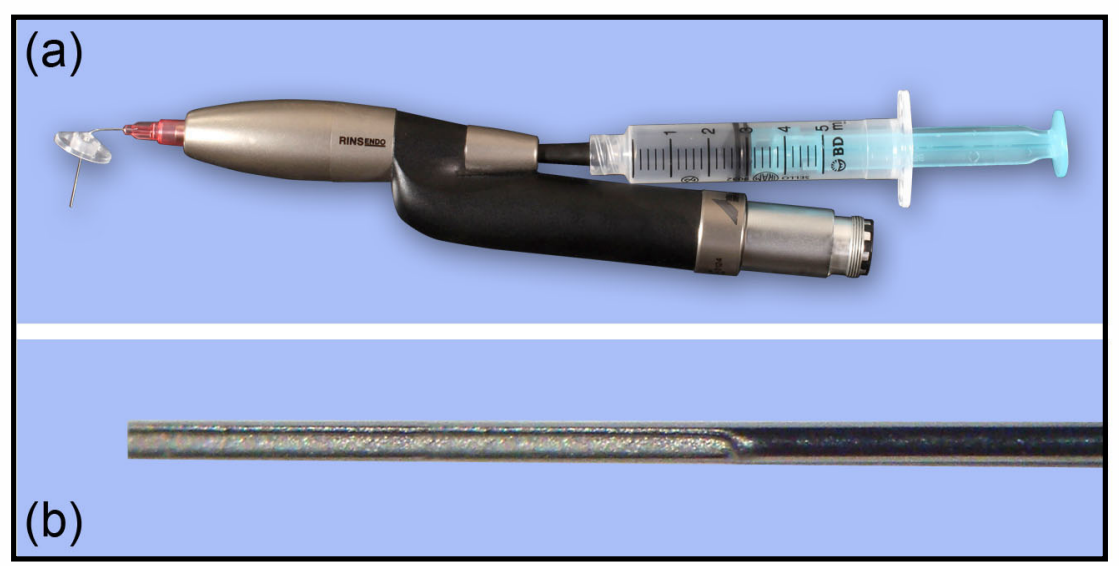

Figura 13. Aparelho de irrigação RinsEndo ${ }^{\circledR}$ (Dürr Dental, Alemanha) utilizada na irrigação hidrodinâmica dos canais radiculares (a). Detalhe da ponta da agulha de irrigação do sistema RinsEndo ${ }^{\circledR}$ com abertura lateral (b).

Os preparos biomecânicos foram realizados por um único operador, especialista em Endodontia, com experiência clínica tanto no sistema endodôntico testado, quanto nos diferentes métodos de irrigação. 


\section{Exame Tomográfico Final}

Posteriormente ao preparo biomecânico, realizou-se novo exame tomográfico dos grupos, seguindo o mesmo protocolo descrito para o exame tomográfico inicial, com o intuito de comparar nas imagens as medidas das áreas da região apical cirúrgica, tanto pelo método clínico, quanto pelo tomográfico computadorizado no comprimento de trabalho.

\section{Análise da área em milímetros quadrados das regiões anatômicas e cirúrgicas das} amostras no comprimento de trabalho.

Para a mensuração da área da região apical no comprimento de trabalho das amostras, foram realizadas análises dos topogramas com o programa IcatVision ${ }^{\circledR}$ (Dental Imaging System, Salt Lake City, USA), o qual realizou a varredura de cada dente no sentido apicocoronário até que se visualizasse o forame apical, a partir desta, mensurou-se $1 \mathrm{~mm}$ em direção à coroa para estabelecer o ponto exato de análise (Figura 14). A imagem então foi selecionada e identificada com o número referente do dente, com a "ferramenta distância", foi criado uma linha de 5 milímetros logo abaixo da amostra para servir como padrão para a calibragem da ferramenta que posteriormente faria a mensuração da área.

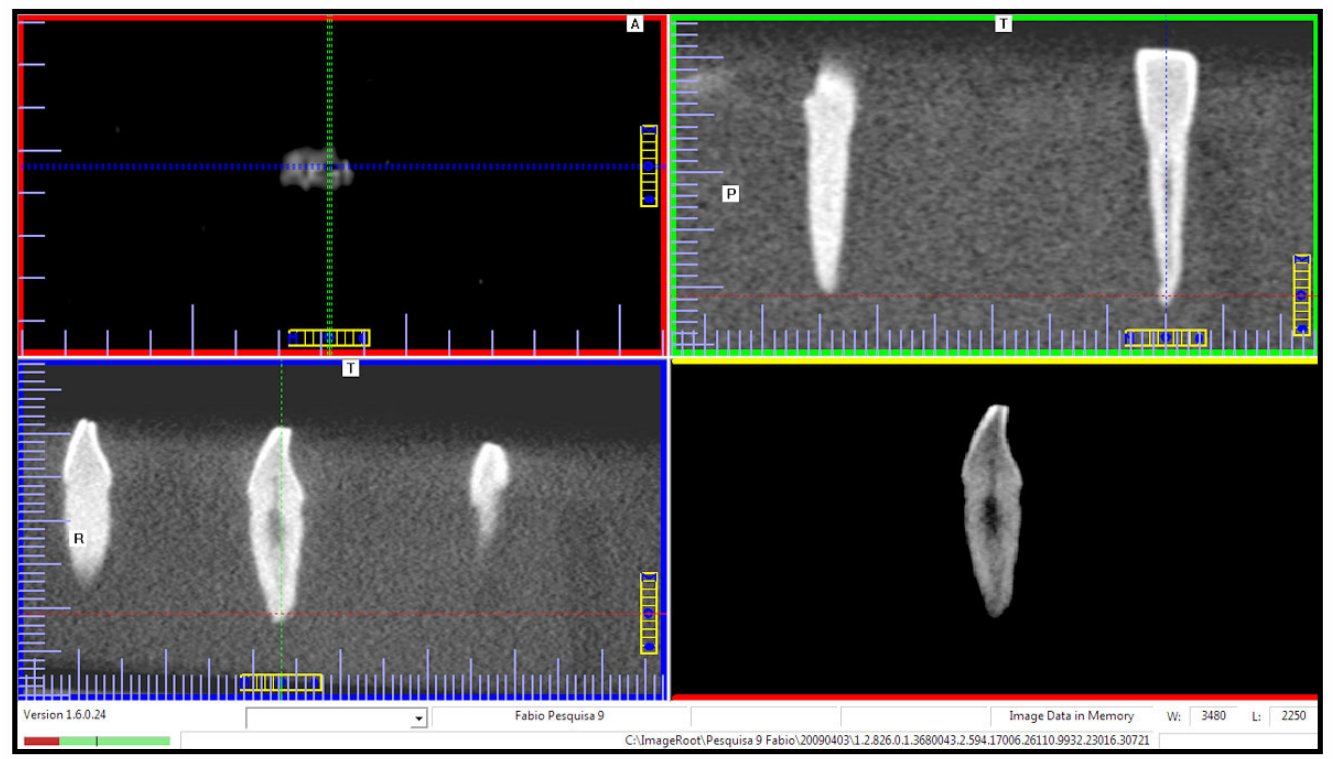

Figura 14. Tela fornecida pelo programa para visualização e análise das imagens tomográficas. 
Para a realização da mensuração da área da amostra, foi utilizada a "ferramenta área" do software Imagetool ${ }^{\circledR} 3.0$ for Windows ${ }^{\circledR}$ (University of Texas Health Science Center, San Antonio, TX, EUA). Esta medida foi realizada em milímetros quadrados nos espécimes antes e após o preparo biomecânico dos canais radiculares (Figura 15) e, posteriormente anotada para comparação e análise estatística.

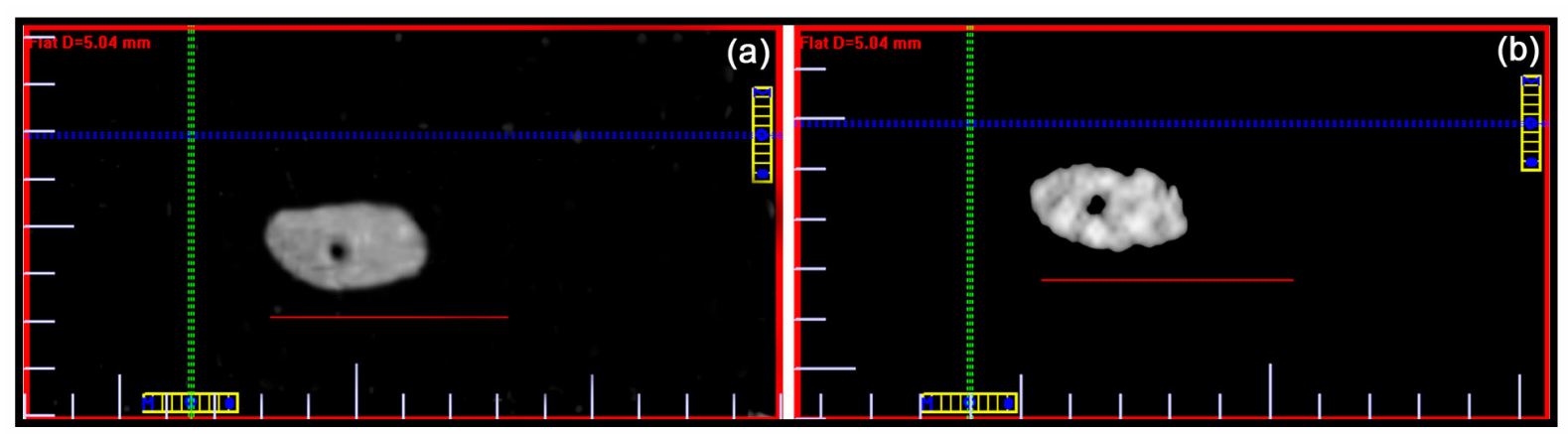

Figura 15. Esquema das imagens tomográficas inicial (área anatômica) em (a) e final (área cirúrgica) em (b) dos espécimes no CT.

Cumpre salientar que as imagens dos espécimes foram analisadas e as áreas apicais anatômicas e cirúrgicas no comprimento de trabalho, mensuradas por três profissionais com o título mínimo de mestre em Odontologia (valores expressos na Tabela I).

\section{Preparo histológico dos espécimes}

Após o preparo dos canais radiculares e exame tomográfico final, os espécimes foram removidos do padrão de acrílico e imersos em recipientes individuais e devidamente identificados, contendo solução de formol a $10 \%$ onde permaneceram armazenados por 12 horas, com o intuito de fixar os detritos orgânicos remanescentes.

Findo este período, os espécimes foram lavados em água corrente por uma hora e colocados em frascos individuais, também identificados, contendo solução aquosa de ácido tricloroacético a $10 \%$, a qual foi renovada a cada 24 horas, durante o período de cinco dias, 
tempo suficiente para que ocorresse a descalcificação dos dentes. Após a descalcificação, os espécimes foram lavados em água corrente por doze horas para remover os resíduos do agente de descalcificação. A seguir foram neutralizados com solução de sulfato de sódio a $4 \%$ durante quinze minutos, e após este período, lavados em água corrente por quinze minutos. As coroas dos espécimes foram seccionadas no colo anatômico com uma lâmina de bisturi número 15. As raízes foram medidas com um paquímetro eletrônico digital Digimess ${ }^{\circledR}$ (Shinko Precision Gaging LTD, China) e divididas em três partes iguais, com objetivo de estabelecer os terços, cervical, médio e apical. Estes cortes também foram realizados com o auxílio de uma lâmina de bisturi. Os terços cervicais e médios foram desprezados e os terços apicais foram submetidos ao processamento histológico.

Para o processo histotécnico, foi utilizado o Processador automático de tecidos Leica TP $1010^{\circledR}$ (Leica Instruments GmbH, Nussloch, Germany), que contém 12 estações, sendo 10 copos tipo Baker e 2 canecas térmicas para banhos de parafina. Cumpre salientar que, cada estação do Processador automático possui uma hora de duração. Inicialmente, os terços apicais foram submetidos ao processo de desidratação em uma série de álcoois de concentração crescente $(70 \%, 80 \%, 90 \%)$, seguido de mais três banhos de álcool absoluto.

Realizada a desidratação, os espécimes foram submetidos a um banho com álcool xilol (50\% álcool e 50\% xilol) e, em seguida, submetidos ao processo de diafanização em três banhos de xilol. Ao término da desidratação e diafanização, os espécimes receberam dois banhos em parafina fundida para que posteriormente fossem incluídos em parafina no aparelho Leica Histoembedder ${ }^{\circledR}$ (Leica InstrumentsGmbH, Nussloch, Germany), concluindo assim o processo histotécnico. Os blocos foram posicionados no micrótomo Leica RM $2145^{\circledR}$ (Leica Instruments GmbH, Nussloch, Germany) (Figura 16), e cortes com cinco micrometros de espessura foram realizados, desprezando-se o milímetro apical. 


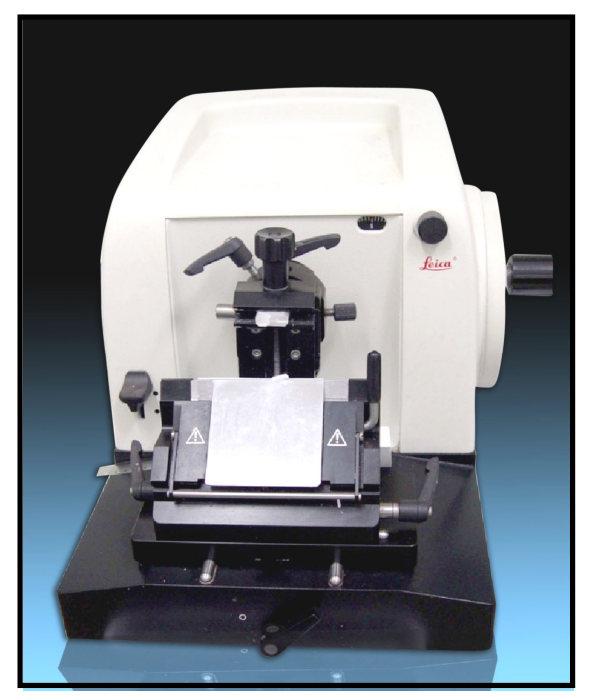

Figura 16. Micrótomo Leica RM $2145^{\circledR}$ (Leica Instruments $\mathrm{GmbH}$, Nussloch, Germany).

A seguir, os cortes foram distendidos em banho histológico (ANCAP, São Paulo, Brasil) (Figura 17) em temperatura de 32C e colocados em lâminas de vidro.

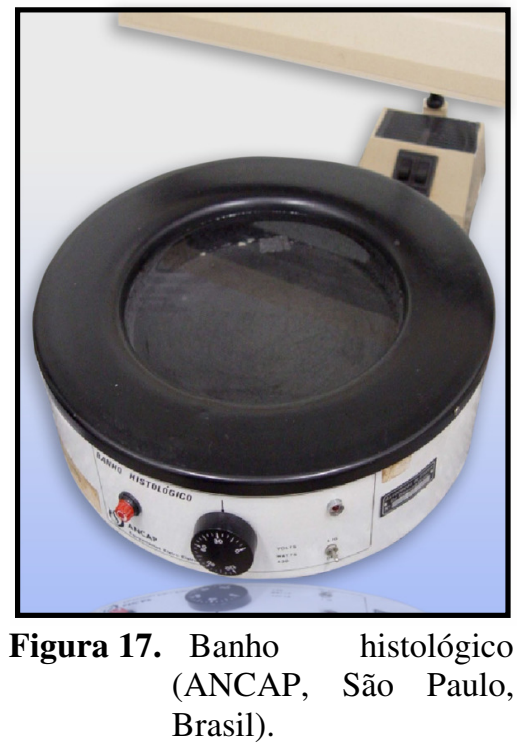

As lâminas foram levadas à estufa a $60^{\circ} \mathrm{C}$ para remoção total do excesso de parafina. Completando-se a remoção da parafina, foi iniciada a coloração das lâminas com hematoxilina e eosina. O processo de coloração foi iniciado com três banhos de xilol, com tempo de cinco minutos cada, seguidos por banho de álcool xilol e três banhos de álcool 
absoluto de quinze segundos cada. Com a finalidade de reidratar os cortes, foram feitos banhos em uma série de álcoois em concentração descendente $(95 \%, 80 \%, 50 \%)$ com duração de quinze segundos cada. Após a reidratação foi realizada a lavagem final em água corrente.

As lâminas com os cortes montados foram imersas em hematoxilina por quatro minutos e, a seguir, lavadas em água corrente por cinco minutos, para que ocorresse a remoção do excesso do corante. Feito isso, as lâminas foram imersas durante cinco segundos em solução de álcool ácido para a diferenciação.

Continuando o processo, as lâminas foram novamente lavadas em água corrente por cinco minutos. Após essa etapa, os cortes foram imersos em álcool $70 \%$ por quinze segundos e depois em eosina por vinte segundos. Removidos da eosina, foram imersos em dois banhos de álcool 96\%, com duração de quinze segundos cada, com o objetivo de remover o excesso do corante.

Removido os excessos, as lâminas foram submetidas a três banhos sucessivos de álcool absoluto, por vinte segundos cada e, posteriormente, a um banho em álcool xilol por quinze segundos. Terminado esse processo, as lâminas receberam três banhos de xilol, com duração de quinze segundos cada.

Encerrado o processo de coloração, as lamínulas foram colocadas sobre os cortes com resina líquida SP15-500 Toluene Solution UN1294 (Permount ${ }^{\circledR}$ Fisher Scientific, New Jersey, USA), para serem posteriormente observadas em microscópio óptico para na sequência ser realizada à análise morfométrica.

\section{Análise morfométrica}

Para o estudo morfométrico, foram selecionados 10 cortes de cada espécime. Com a finalidade de se avaliar a região mais próxima do comprimento de trabalho, foram descartados os primeiros 50 cortes, sendo o corte seguinte (corte 51) separado para a morfometria. A partir 116 
do corte 51, sucessivamente, foram selecionados 10 cortes de cada raiz. Um microscópio óptico Eclipse E 600 (Nikon, Shinagawa-ku, Tokio, Japão) com uma ocular de 4X/0.13 e objetiva de ampliação de 10X/25 foi utilizado, obtendo-se um aumento final de 40X. As imagens foram capturadas por meio do software Movie Maker ${ }^{\circledR}$ (Microsoft, USA).

\section{Determinação da área ocupada por débris}

A imagem foi analisada por meio do software Imagetool $^{\circledR} 3.0$ for Windows (University of Texas Health Science Center, San Antonio, TX, EUA), utilizando-se da "ferramenta de área”, mensurando a área total do canal e a área que continha débris, posteriormente por meio de uma regra de três foi possível calcular a porcentagem da área suja de cada canal radicular (Figura 18).

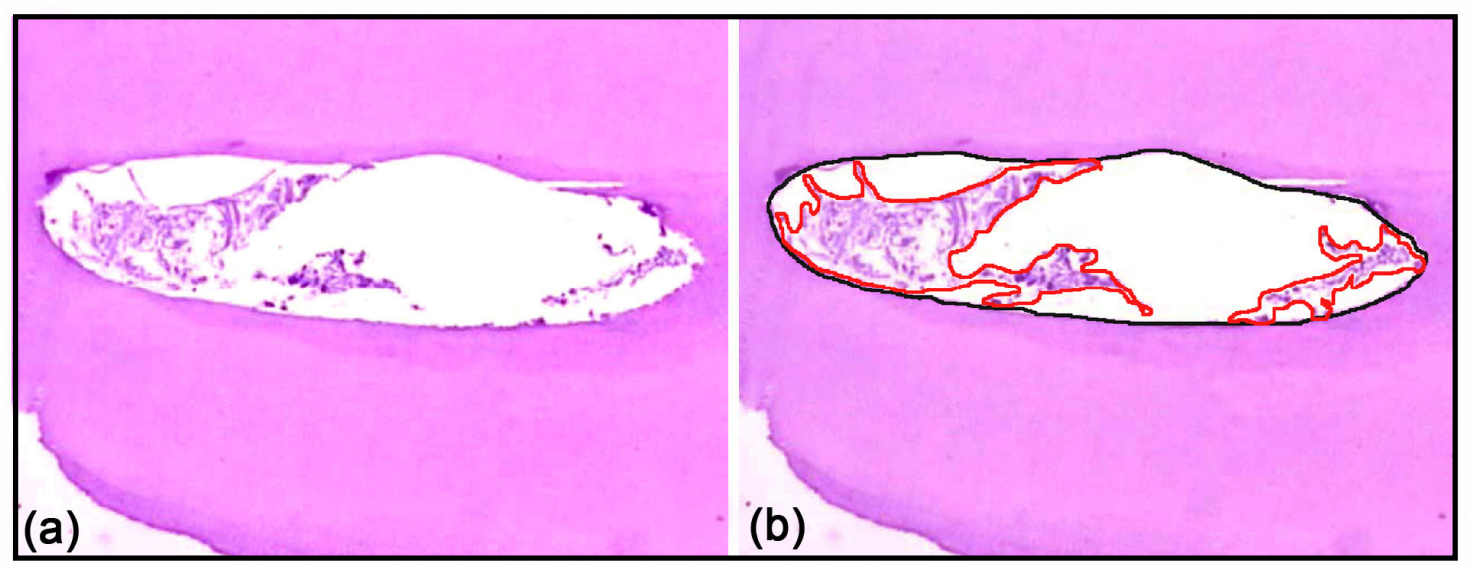

Figura 18. Fotomicrografia da região apical com 40 vezes de aumento (a), e (b) imagem da região avaliada dividindo a área total (linha preta) e a área com débris (linha vermelha).

\section{Determinação do perímetro de ação do instrumento;}

A determinação do perímetro de ação dos instrumentos na secção transversal do canal radicular foi realizada por meio do mesmo processo e programa anteriormente citado, foi mensurada a área em que o instrumento não tocou nas paredes dos canais radiculares, a subtração desta medida do comprimento total do canal, resultou na área em que o instrumento 
foi efetivo. A atuação do instrumento na parede do canal radicular foi determinada a partir das seguintes observações: regularidade da superfície, mudança brusca da continuidade na parede e, remoção parcial, ou total da camada de pré-dentina (Figura 19).

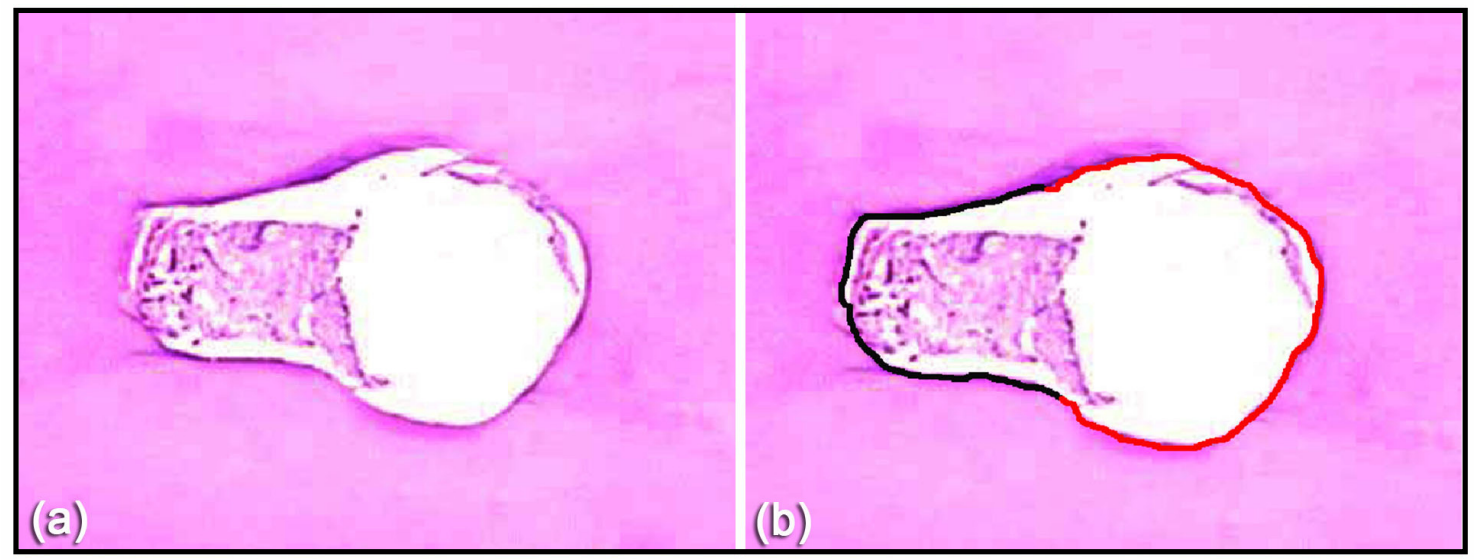

Figura 19. Fotomicrografia da região apical com $40 \mathrm{X}$ de aumento (a), e (b) imagem da mesma região com as demarcações das áreas onde não houve contato do instrumento (linha preta) e onde o instrumento tocou nas paredes dos canais radiculares (linha vermelha).

\section{Critérios utilizados para a análise histológica}

A análise histológica foi realizada observando-se os seguintes aspectos:

- Presença ou ausência de débris e restos de polpa nas paredes dos canais radiculares

- Visualização das áreas não tocadas, da camada de pré-dentina e regularidade das paredes dos canais radiculares.

Os resultados foram anotados em ficha devidamente preenchida com os dados visualizados. A análise estatística dos resultados obtidos da comparação das áreas das regiões anatômicas e cirúrgicas pelo método clínico e por meio da tomografia computadorizada e da limpeza promovida pelos diferentes métodos de irrigação e diâmetro de instrumentação foi realizada com o auxílio do software GrafPad ${ }^{\circledR}$ Prism, versão 5.0 (GraphPad Software Inc., EUA).

O organograma contendo o esquema do experimento pode ser visto na figura 20. 


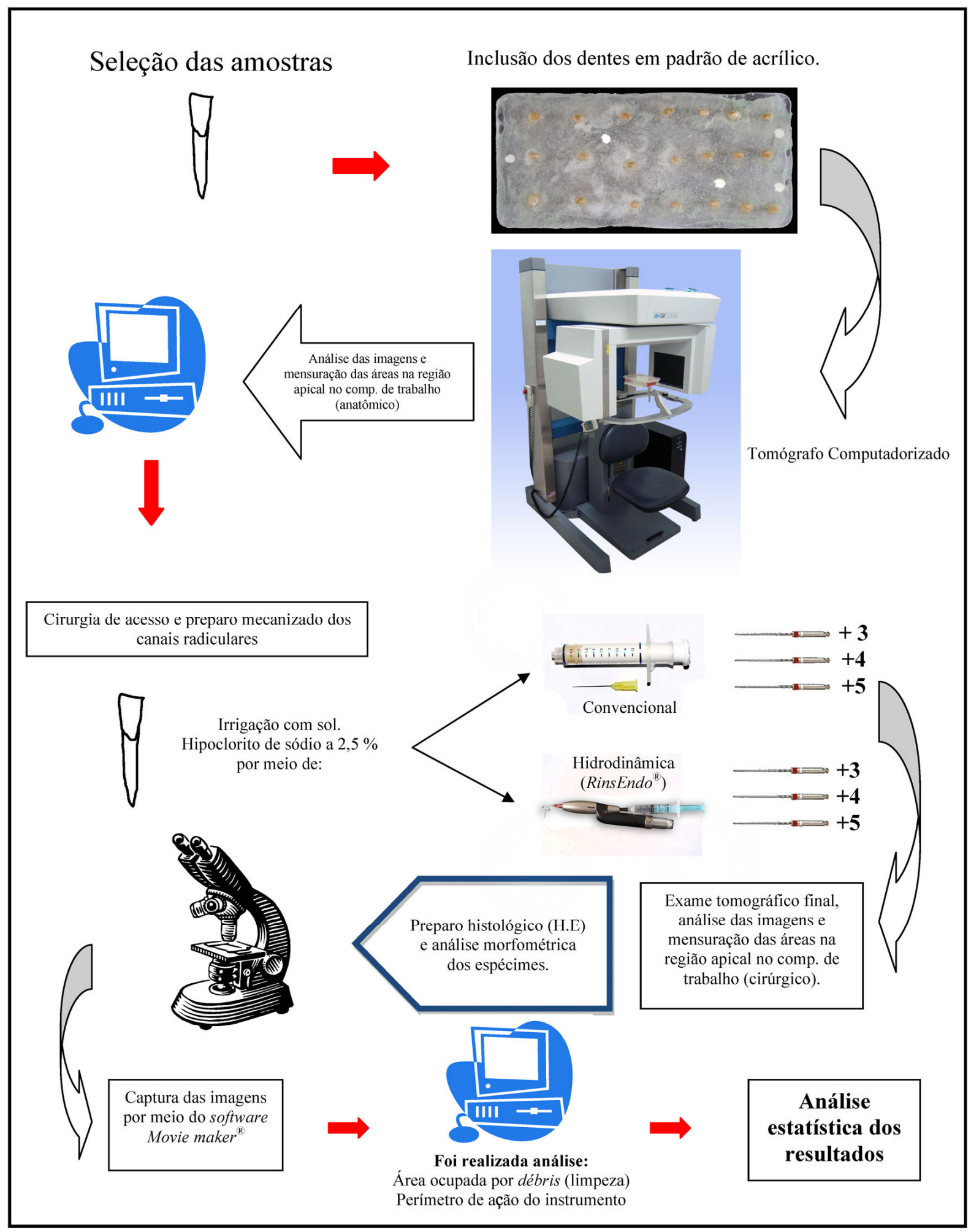

Figura 20. Organograma com o esquema do experimento. 
Resultados 


\section{Determinação da área apical anatômica e cirúrgica no comprimento de trabalho.}

Os valores obtidos pela mensuração das áreas no comprimento de trabalho $(1 \mathrm{~mm}$ aquém do forame apical), por meio do método tomográfico antes (anatômico) e após (cirúrgico) o preparo dos canais radiculares, encontram-se expressos na tabela I.

Quanto aos valores resultantes da mensuração das áreas no comprimento de trabalho, mas realizado pelo método clínico, foram determinados teoricamente na área circular ocupada pela lima, e seus valores encontram-se demonstrados na tabela II.

Tabela I. Dados em milímetros quadrados das áreas apicais das regiões correspondentes ao comprimento de trabalho das amostras (Tomógrafo Computadorizado).

\section{Áreas apicais obtidas pelo Tomógrafo Computadorizado}

\begin{tabular}{|c|c|c|c|c|c|c|c|c|c|c|c|}
\hline \multicolumn{6}{|c|}{ Anatômico } & \multicolumn{6}{|c|}{ Cirúrgico } \\
\hline 0,041 & 0,028 & 0,067 & 0,057 & 0,019 & 0,079 & 0,128 & 0,075 & 0,166 & 0,164 & 0,091 & 0,220 \\
\hline 0,024 & 0,035 & 0,020 & 0,027 & 0,044 & 0,037 & 0,098 & 0,156 & 0,123 & 0,076 & 0,112 & 0,105 \\
\hline 0,020 & 0,016 & 0,060 & 0,044 & 0,025 & 0,102 & 0,148 & 0,175 & 0,161 & 0,114 & 0,151 & 0,141 \\
\hline 0,067 & 0,082 & 0,086 & 0,035 & 0,030 & 0,024 & 0,096 & 0,073 & 0,167 & 0,110 & 0,104 & 0,176 \\
\hline 0,021 & 0,047 & 0,011 & 0,024 & 0,045 & 0,039 & 0,099 & 0,101 & 0,080 & 0,124 & 0,113 & 0,107 \\
\hline 0,015 & 0,029 & 0,092 & 0,026 & 0,142 & 0,104 & 0,071 & 0,166 & 0,141 & 0,090 & 0,123 & 0,095 \\
\hline 0,043 & 0,082 & 0,046 & 0,028 & 0,040 & 0,075 & 0,088 & 0,113 & 0,128 & 0,062 & 0,115 & 0,197 \\
\hline \multicolumn{6}{|c|}{ Média 0,047 \pm 0,029 } & \multicolumn{6}{|c|}{ Média 0,122 \pm 0,037 } \\
\hline
\end{tabular}


Tabela II. Dados em milímetros quadrados das áreas apicais das regiões correspondentes ao comprimento de trabalho das amostras (Clínico).

\section{Áreas apicais obtidas pelo método clínico}

\begin{tabular}{|c|c|c|c|c|c|c|c|c|c|c|c|}
\hline \multicolumn{6}{|c|}{ Anatômico } & \multicolumn{6}{|c|}{ Cirúrgico } \\
\hline 0,071 & 0,126 & 0,049 & 0,096 & 0,049 & 0,049 & 0,126 & 0,159 & 0,238 & 0,159 & 0,126 & 0,238 \\
\hline 0,071 & 0,049 & 0,071 & 0,071 & 0,049 & 0,049 & 0,159 & 0,196 & 0,196 & 0,126 & 0,126 & 0,159 \\
\hline 0,049 & 0,071 & 0,071 & 0,071 & 0,031 & 0,071 & 0,126 & 0,159 & 0,238 & 0,159 & 0,159 & 0,283 \\
\hline 0,071 & 0,049 & 0,049 & 0,096 & 0,071 & 0,031 & 0,126 & 0,196 & 0,238 & 0,126 & 0,159 & 0,159 \\
\hline 0,031 & 0,031 & 0,031 & 0,071 & 0,031 & 0,071 & 0,096 & 0,159 & 0,159 & 0,096 & 0,159 & 0,196 \\
\hline 0,049 & 0,031 & 0,031 & 0,049 & 0,049 & 0,031 & 0,096 & 0,126 & 0,196 & 0,159 & 0,126 & 0,238 \\
\hline 0,031 & 0,049 & 0,031 & 0,031 & 0,049 & 0,049 & 0,096 & 0,126 & 0,159 & 0,096 & 0,196 & 0,283 \\
\hline \multicolumn{6}{|c|}{ Média 0,054 $\pm 0,022$} & \multicolumn{6}{|c|}{ Média 0,164 $\pm 0,049$} \\
\hline
\end{tabular}

Os dados das tabelas I e II foram agrupados para realizar-se a estatística descritiva e determinar a natureza da distribuição amostral. Os resultados da estatística descritiva e o teste de normalidade estão expressos na tabela III.

Tabela III. Estatística descritiva e teste de normalidade de D'Agostino e Pearson.

\begin{tabular}{lrrrr}
\hline Estatística descritiva & & & & \\
& A. A. (clínico) & A. A. (tomo) & A. C. (clínico) & A. C. (tomo) \\
Valores analisados: & 42 & 42 & 42 & 42 \\
Média & 0,054 & 0,047 & 0,164 & 0,122 \\
Desvio-padrão & 0,022 & 0,029 & 0,049 & 0,037 \\
Erro-padrão & 0,003 & 0,005 & 0,008 & 0,006 \\
& & & & \\
Teste de normalidade (D'Agostino e Pearson) & & & 0,14 & 0,27 \\
Valor de P & 0,37 & 0,22 & Sim & Sim \\
Passou pelo teste de normalidade $(\alpha=0.05)$ ? & Sim & Sim & n.s. & n.s. \\
Resultado & n.s. & n.s. & &
\end{tabular}

O teste de normalidade de D'Agostino e Pearson indicou uma distribuição gaussiana dos dados amostrais, o que autorizou a realização de um teste paramétrico para o tratamento estatístico dos resultados. 
Estes resultados foram submetidos à análise de variância com dois fatores de variação e dados vinculados (two-way ANOVA), complementado com teste de Bonferroni para comparações múltiplas entre os grupos. Os resultados destes testes encontram-se na tabela IV.

Tabela IV. Análise de variância com dois fatores de variação para dados vinculados e teste complementar de Bonferroni aplicados aos resultados da medida da área da região do comprimento de trabalho.

Fonte de variação

Interação

Diâmetro

Método de mensuração

Fonte de variação

Interação

Área apical

Método de mensuração

Pareamento

Resíduo
\% da variação total

2,07

59,33

4,13

Soma dos quadrados

0,01262

0,3608

0,02511

0,1175

0,09211
Valor de $\mathbf{P}$

0,0012

$\mathrm{P}<0,001$

$\mathrm{P}<0,001$

Teste de comparações múltiplas de Bonferroni

Determinação pelos métodos clínico $\mathrm{x}$ tomográfico

diferença entre médias

$-0,007119$

Anatômica

$-0,04179$
intervalo de confiança $-0,02477$ a 0,01053 $-0,05943 \mathrm{a}-0,02414$
valor de $\mathrm{P}$ $\mathrm{p}>0,05$ $\mathrm{p}<0,001$

A análise de variância revelou haver diferenças significantes entre os métodos de medidas das áreas apicais cirúrgicas $(\mathrm{p}<0,001)$, sendo os maiores resultados observados nos métodos clínicos. Em contrapartida, a análise das áreas apicais anatômicas, pelos diferentes métodos de medida, não apresentaram diferença estatística significante ( $p>0,05)$.

A figura 21 ilustra, de forma gráfica, a média e o desvio-padrão dos resultados obtidos para a determinação das áreas apicais anatômicas e cirúrgicas das amostras observadas. 


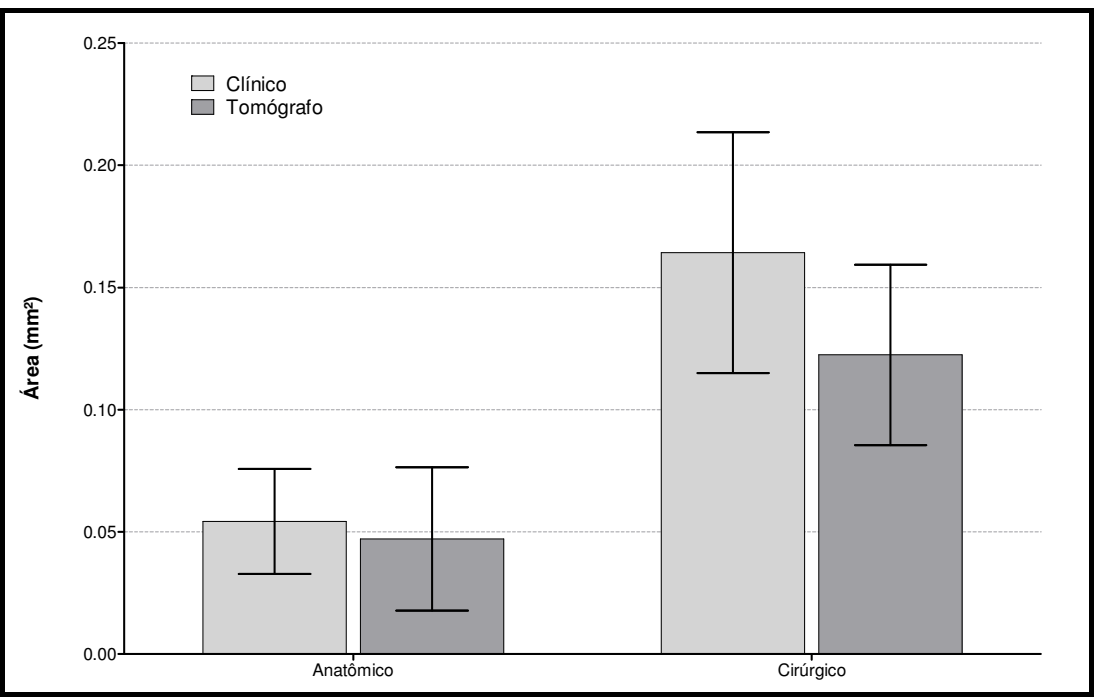

Figura 21. Valores da média e o desvio-padrão dos resultados obtidos para a determinação das áreas apicais anatômicas e cirúrgicas das amostras.

\section{Avaliação da limpeza promovida no terço apical}

A tabela $\mathrm{V}$ ilustra os resultados obtidos pela análise em microscopia óptica das áreas limpas do terço apical para os espécimes irrigados de forma convencional e com a técnica hidrodinâmica.

Tabela V. Valores da área livres de débris após o preparo dos canais radiculares (em porcentagem).

\begin{tabular}{|c|c|c|c|c|c|}
\hline \multicolumn{3}{|c|}{ Irrigação convencional } & \multicolumn{3}{|c|}{ Irrigação hidrodinâmica } \\
\hline IAI + 3 & IAI + 4 & IAI +5 & IAI + 3 & $\mathrm{IAI}+4$ & IAI +5 \\
\hline 100,00 & 77,06 & 89,22 & 84,23 & 84,92 & \\
\hline- & 98,70 & 99,20 & & 97,52 & 98,56 \\
\hline 96,04 & 97,37 & 85,32 & 64,33 & 97,63 & 100,00 \\
\hline 69,95 & 87,19 & - & 100,00 & 94,55 & 100,00 \\
\hline 77,64 & 92,81 & 97,63 & 100,00 & & 76,66 \\
\hline 93,65 & 84,60 & 63,21 & 78,36 & 65,82 & 98,40 \\
\hline 53,56 & 95,98 & 100,00 & 53,25 & 100,00 & 97,99 \\
\hline $81,81 \pm 18,05$ & $90,53 \pm 7,92$ & $89,10 \pm 13,99$ & $80,03 \pm 18,88$ & $90,07 \pm 13,01$ & $95,27 \pm 9,16$ \\
\hline
\end{tabular}

Os resultados que possuem traço são referentes aos espécimes que foram perdidos na manipulação histotécnica; IAI = Instrumento Apical Inicial.

Os resultados da microscopia óptica quanto à limpeza dos canais radiculares foram submetidos ao teste de normalidade (D’Agostino e Pearson) para determinação da natureza da distribuição amostral. Para adequação dos valores a uma curva gaussiana, foi utilizada a 
transformação quadrática dos dados originais. Os resultados deste teste aplicado ao tipo de irrigação encontram-se na tabela VI.

Tabela VI. Estatística descritiva e teste de normalidade de D'Agostino e Pearson. Transformação quadrática dos dados originais.

\begin{tabular}{lcc}
\hline Estatística descritiva & & \\
\hline & Irrigação convencional & Irrigação hidrodinâmica \\
Valores analisados: & 19 & 18 \\
Média & 7797 & 8034 \\
Desvio-padrão & 2156 & 2404 \\
Erro-padrão & 494,6 & 566,7 \\
& & 0,1759 \\
Teste de normalidade (D'Agostino e Pearson) & & Sim \\
Valor de P & 0,1768 & n.s. \\
Passou pelo teste de normalidade $(\alpha=0.05) ?$ & Sim & n.s. \\
Resultado & &
\end{tabular}

O teste de normalidade aplicado ao preparo dos canais radiculares encontra-se na tabela VII. Para adequação dos valores a uma curva gaussiana, também utilizou-se a transformação quadrática dos dados.

Tabela VII. Estatística descritiva e teste de normalidade de D'Agostino e Pearson. Transformação quadrática dos dados originais.

\begin{tabular}{lccc}
\hline Estatística descritiva & & & \\
\hline & IAI + 3 & IAI + 4 & IAI + 5 \\
Valores analisados: & 12 & 13 & 8624 \\
Média & 6833 & 8252 & 1965 \\
Desvio-padrão & 2755 & 1707 & 567,2 \\
Erro-padrão & 795,2 & 473,3 & 0,0560 \\
Teste de normalidade (D'Agostino e Pearson) & & & Sim \\
Valor de P & 0,2357 & 0,1167 & n.s. \\
Passou pelo teste de normalidade $(\alpha=0.05) ?$ & Sim & Sim & n.s. \\
Resultado & n.s. & &
\end{tabular}

Os resultados transformados foram submetidos à análise de variância com dois fatores de variação. Os resultados da análise encontram-se na tabela VIII. 
Tabela VIII. Análise de variância com dois fatores de variação aplicada transformação quadrática dos resultados originais das áreas isentas de débris após o preparo dos canais radiculares.

\begin{tabular}{|c|c|c|c|}
\hline Fonte de variação & \% da variação total & Valor de $p$ & \\
\hline Interação & 1,58 & 0,7553 & \\
\hline Instrumentação & 11,81 & 0,1369 & \\
\hline Irrigação & 0,35 & 0,7261 & \\
\hline Fonte de variação & Soma dos quadrados & Quadrado médio & Valor de f \\
\hline Interação & 2876000 & 1438000 & 0,2832 \\
\hline Instrumentação & 21550000 & 10770000 & 2,122 \\
\hline Irrigação & 634400 & 634400 & 0,1249 \\
\hline Resíduo & 157400000 & 5078000 & \\
\hline
\end{tabular}

A análise estatística revelou não haver diferenças significantes entre os tipos de irrigação testados $(p=0,73)$ ou entre as instrumentações $(p=0,14)$, razão pela qual não foi realizado o teste complementar de Bonferroni.

Assim, a porcentagem de limpeza obtida na região apical dos dentes instrumentados e irrigados com técnica convencional versus técnica hidrodinâmica não apresentaram diferença estatística significante.

Os valores da limpeza da região apical promovida após o preparo dos canais radiculares com diferentes métodos de irrigação e técnicas de instrumentação dos canais radiculares encontram-se expressos em forma gráfica na figura 22.

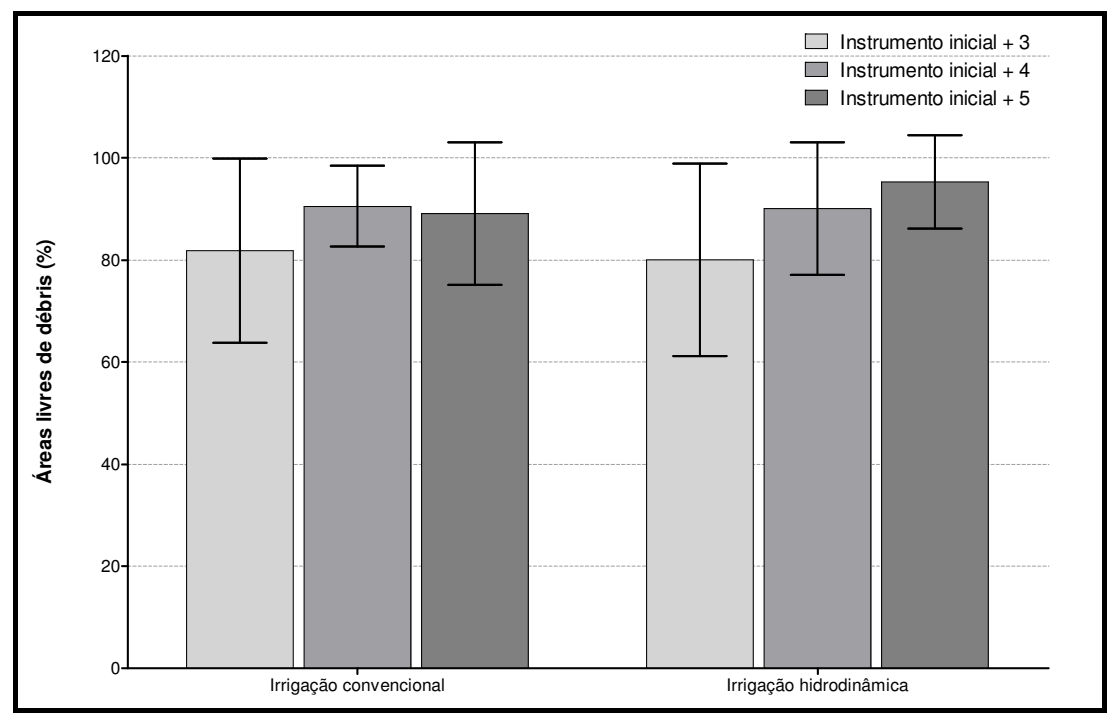

Figura 22. $\quad$ Valores da área livre de débris após o preparo dos canais radiculares com diferentes métodos de irrigação e técnicas de instrumentação dos canais radiculares. 


\section{Ação dos instrumentos nas paredes dos canais radiculares no comprimento de trabalho.}

Os resultados correspondentes à porcentagem da extensão de atuação do instrumento nas paredes do canal radicular estão elencados na tabela IX.

Tabela IX. Porcentagem da dentina radicular da secção transversal apical onde houve atuação do instrumento (Valores originais).

\begin{tabular}{|c|c|c|c|c|c|}
\hline \multicolumn{3}{|c|}{ Irrigação convencional } & \multicolumn{3}{|c|}{ Irrigação hidrodinâmica } \\
\hline IAI + 3 & IAI + 4 & IAI +5 & IAI +3 & $\mathrm{IAI}+4$ & IAI +5 \\
\hline 4,7 & 75,32 & 49,47 & 59,39 & 58,82 & - \\
\hline - & 18,84 & 91,18 & - & 73,29 & 90 \\
\hline 20,89 & 58,33 & 67,86 & 2,50 & 88,98 & 100 \\
\hline 47,66 & 63,50 & - & 26,35 & 95,27 & 72,85 \\
\hline 40,26 & 77,39 & 93,71 & 43,11 & - & 82,01 \\
\hline 19,39 & 65,25 & 96,73 & 40 & 64,44 & 93,09 \\
\hline 27,48 & 78,94 & 93,01 & 16,36 & 97,50 & 93,60 \\
\hline
\end{tabular}

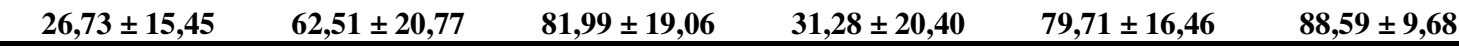

Os resultados que possuem traço são referentes aos espécimes que foram perdidos na manipulação histotécnica; IAI = Instrumento Apical Inicial.

A figura 23 ilustra, de forma gráfica, a média e o desvio-padrão dos resultados obtidos para a porcentagem de dentina radicular da região apical onde houve atuação do instrumento.

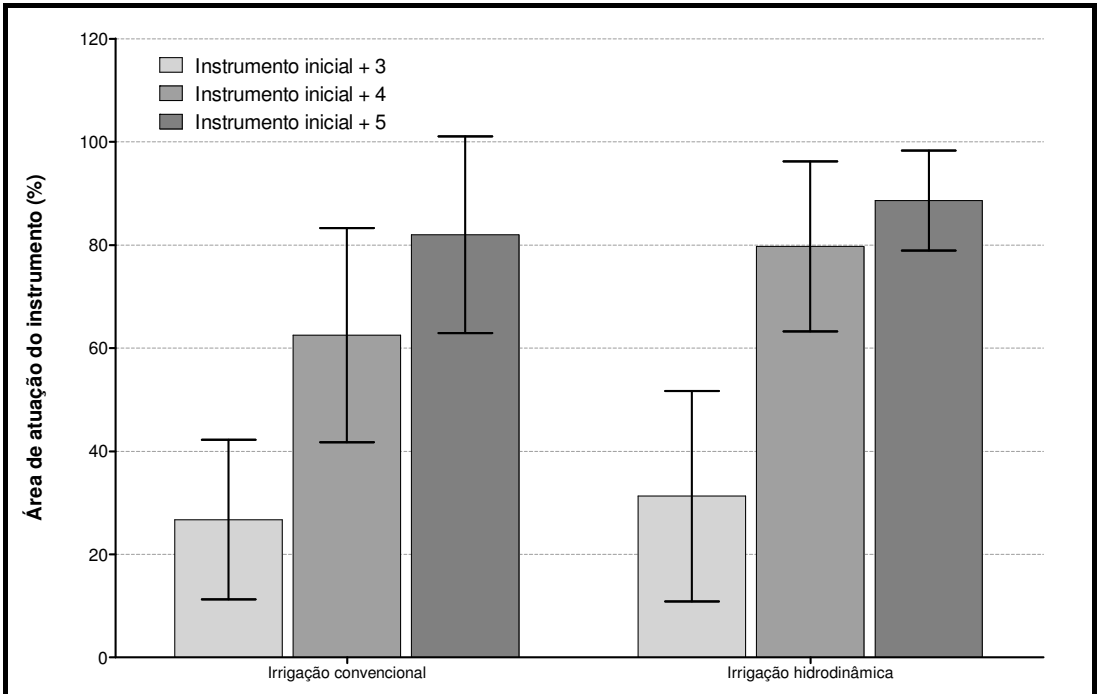

Figura 23. Valores obtidos para a porcentagem de dentina radicular da região apical onde houve atuação do instrumento. 
A tabela $\mathrm{X}$ ilustra os resultados obtidos para o teste de normalidade. Os resultados foram transformados (transformação quadrática) para adequação à curva normal.

Tabela X. Estatística descritiva e teste de normalidade de D'Agostino e Pearson. Transformação quadrática dos dados originais.

\begin{tabular}{lccc}
\hline Estatística descritiva & & & \\
\hline & IAI + 3 & IAI + 4 & IAI + 5 \\
Valores analisados: & 12 & 13 & 12 \\
Média & 1120 & 5340 & 7476 \\
Desvio-padrão & 1073 & 2512 & 2255 \\
Erro-padrão & 309,6 & 696,7 & 651,0 \\
& & & \\
Teste de normalidade (D'Agostino e Pearson) & 0,1867 & 0,9258 & 0,1116 \\
Valor de P & Sim & Sim & Sim \\
Passou pelo teste de normalidade $(\alpha=0.05) ?$ & n.s. & n.s. & n.s. \\
Resultado & &
\end{tabular}

Os resultados transformados foram submetidos à análise de variância com dois fatores de variação. Os resultados da análise estatística encontram-se na tabela XI.

Tabela XI. Análise de variância com dois fatores de variação e teste complementar de Bonferroni aplicados à porcentagem da dentina radicular da secção transversal apical onde houve atuação do instrumento. Transformação quadrática dos dados originais.

\begin{tabular}{lrrr}
\hline Fonte de variação & \% da variação total & Valor de P & \\
Interação & 1,53 & 0,4783 & \\
Instrumentação & 63,95 & $\mathrm{P}<0.0001$ & \\
Irrigação & 3,38 & 0,0772 & \\
& & & \\
Fonte de variação & Soma dos quadrados & Quadrado médio & Valor de f \\
Interação & 6055000 & 3027000 & 0,7554 \\
Instrumentação & 253200000 & 126600000 & 31,59 \\
Irrigação & 13390000 & 13390000 & 3,342 \\
Resíduo & 124200000 & 4008000 &
\end{tabular}

Teste de comparações múltiplas de Bonferroni

IAI + 3 vs. IAI + 4

Irrigação convencional

Irrigação hidrodinâmica

IAI +3 vs. IAI + 5

Irrigação convencional

Irrigação hidrodinâmica

IAI + 4 vs. IAI + 5

Irrigação convencional

Irrigação hidrodinâmica diferença entre médias

3364

5255

diferença entre médias

6112

6601

diferença entre médias

2749

1346 intervalo de confiança

224.6 to 6503

1998 to 8512

valor de $p$

$\mathrm{P}<0,05$

$\mathrm{P}<0,001$
intervalo de confiança
2855 to 9370
3343 to 9858

valor de $\mathrm{p}$

$\mathrm{P}<0,001$

$\mathrm{P}<0,001$

intervalo de confiança

-390.4 to 5888

-1912 to 4603 valor de $\mathrm{p}$

$\mathrm{P}>0,05$ $\mathrm{P}>0,05$ 
Enquanto o método de irrigação não teve um impacto significativo na extensão de atuação do instrumento nas paredes do canal radicular $(\mathrm{p}=0,11)$, a análise estatística revelou haver diferenças entre os grupos testados no que tange às diferentes técnicas de instrumentação $(\mathrm{p}<0,001)$. O preparo biomecânico com 4 instrumentos acima do instrumento apical inicial determinou uma área de atuação significantemente superior ao mesmo preparo com apenas 3 instrumentos. O preparo com 5 instrumentos acima do instrumento apical inicial, entretanto, não foi capaz de melhorar o preparo das paredes do terço apical quando comparado ao preparo produzido por 4 limas além do instrumento apical inicial ( $p>0,05)$.

\section{Análise da geometria apical dos canais radiculares no comprimento de trabalho.}

As tabelas XII e XIII demonstram a porcentagem dos resultados obtidos quanto à análise da geometria apical dos canais radiculares no comprimento de trabalho dos incisivos inferiores, que independente do método de análise utilizado, os resultados foram os mesmos. Apresentando a maior prevalência da forma elíptica nos canais radiculares na porção apical.

Tabela XII. Análise da geometria apical dos canais radiculares (CT) por meio de tomografia computadorizada $(\%)$.

\begin{tabular}{l|cc}
\hline & \multicolumn{2}{|c}{ Geometria apical dos canais radiculares por meio de Tomógrafo } \\
& Anatômico(inicial) & Cirúrgico (final) \\
\cline { 2 - 2 } & 52,3 & 66,6 \\
Elíptico & 42 & 28,7 \\
Circular & 4,7 & 4,7 \\
Irregular & & \\
\hline
\end{tabular}

A figura 24 ilustra, de forma gráfica, a porcentagem dos resultados obtidos para a análise da geometria da região apical dos canais radiculares por meio do exame tomográfico. 


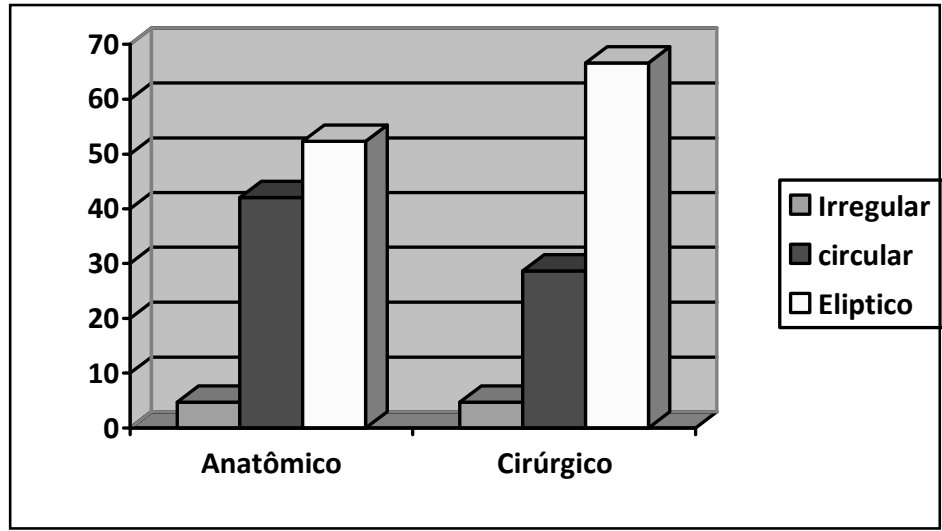

Figura 24. Porcentagem da geometria visualizada nos canais radiculares na região apical (CT) por meio da tomografia computadorizada inicial (anatômica) e final (cirúrgica).

Tabela XIII. Análise da geometria apical dos canais radiculares (CT) por meio histológico e tomográfico $(\%)$.

\begin{tabular}{l|cc}
\hline & \multicolumn{2}{|c}{ Geometria apical dos canais radiculares por diferentes meios } \\
& Cirúrgico (histológico) & Cirúrgico (tomográfico) \\
Elíptico & 56,6 & 66,6 \\
Circular & 37 & 28,7 \\
Irregular & 5,4 & 4,7 \\
\hline
\end{tabular}

A figura 25 compara de forma percentual a geometria apical obtida pelos métodos histológico e tomográfico.

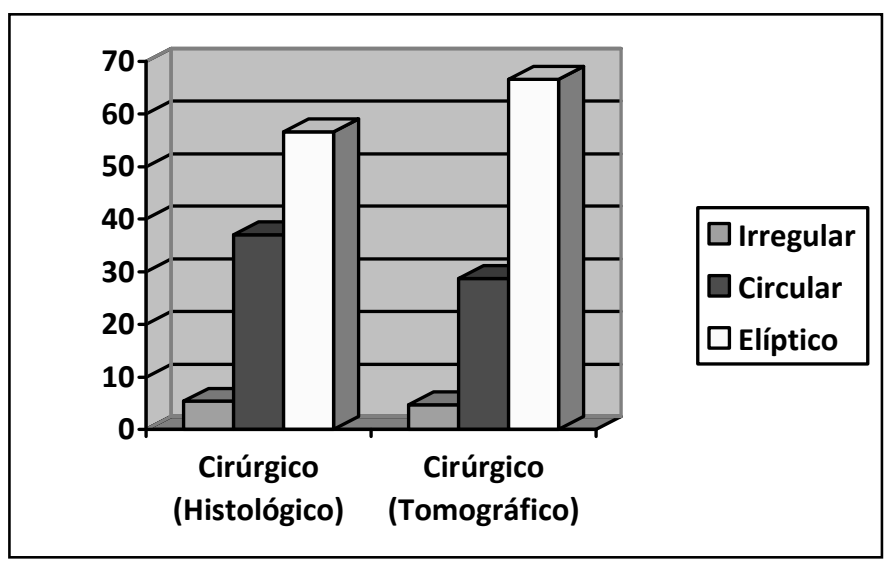

Figura 25. Porcentagem da geometria visualizada nos canais radiculares na região apical $(\mathrm{CT})$ por meio histológico e tomográfico após preparo dos canais radiculares. 
Fotomicrografia da obtenção da área apical anatômica e cirúrgica dos canais radiculares no comprimento de trabalho.

As figuras 26 e 27 ilustram um espécime observado em tomografia computadorizada cone beam, antes e após o preparo biomecânico.

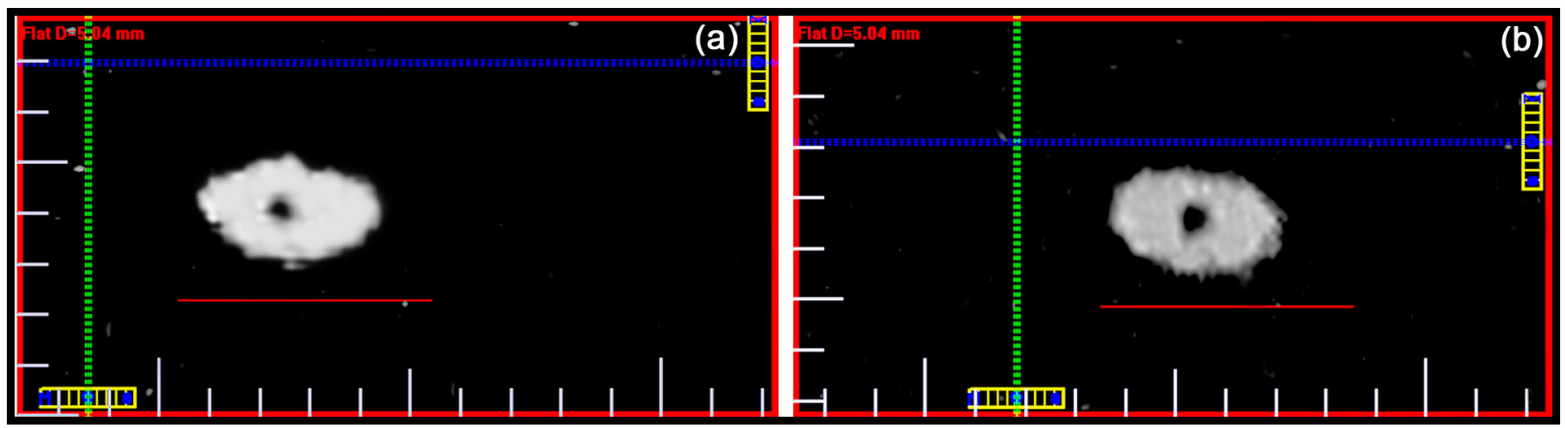

Figura 26. Topogramas da região apical no comprimento de trabalho dos espécimes obtidos por meio da tomografia computadorizada cone beam. Área anatômica do elemento número 3 (a) e área cirúrgica do mesmo elemento (b).

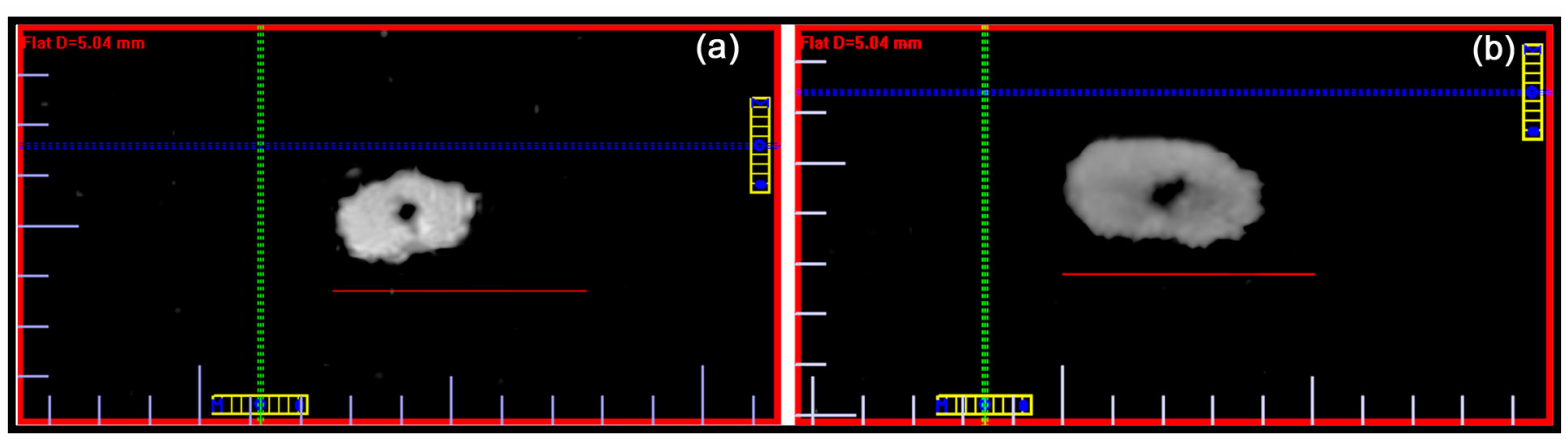

Figura 27. Topogramas da região apical no comprimento de trabalho dos espécimes obtidos por meio da tomografia computadorizada cone beam. Área anatômica do elemento número 21 (a) e área cirúrgica do mesmo elemento (b).

\section{Fotomicrografia da limpeza promovida nos canais radiculares pós preparo.}

As figuras 28, 29 e 30 apresentam fotomicrografias da região apical de espécimes representativos dos grupos testados. 


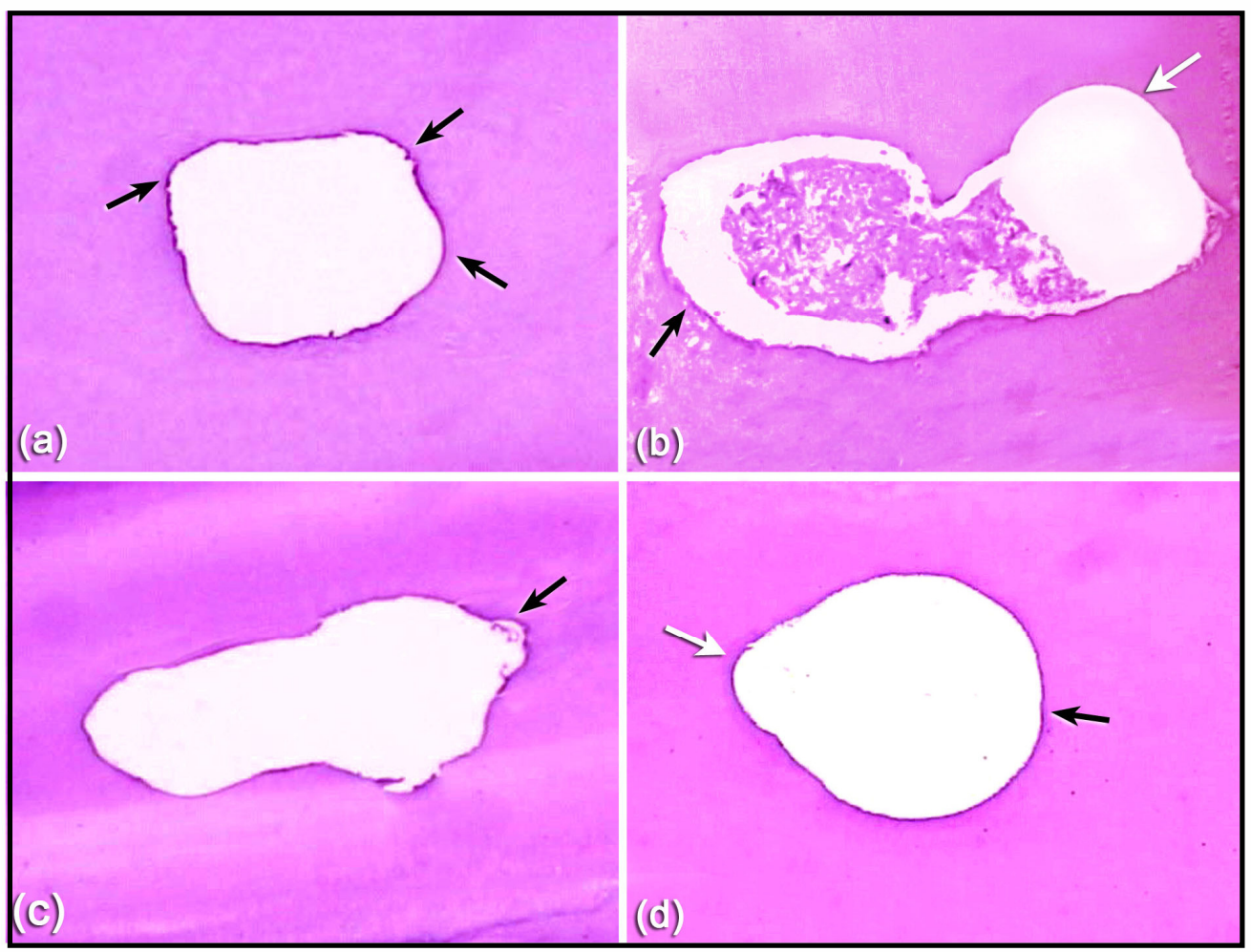

Figura 28. Fotomicrografias da região apical dos espécimes do grupo I, com aumento de 40X. Em (a), canal radicular apresentando áreas (setas) em que o instrumento não tocou nas paredes (três instrumentos acima do IAI) e ausência de débris; (b), canal achatado preparado com três instrumentos acima do IAI apresentando débris na luz de seu canal, onde o instrumento não foi efetivo (seta preta), e área onde o instrumento tocou nas paredes (seta branca); (c), região não instrumentada apresentando débris (seta) em um canal acentuadamente achatado preparado com quatro instrumentos acima do IAI; (d), paredes instrumentadas (seta preta) e não preparadas (seta branca), canal preparado com cinco instrumentos acima do IAI e ausência de débris. 


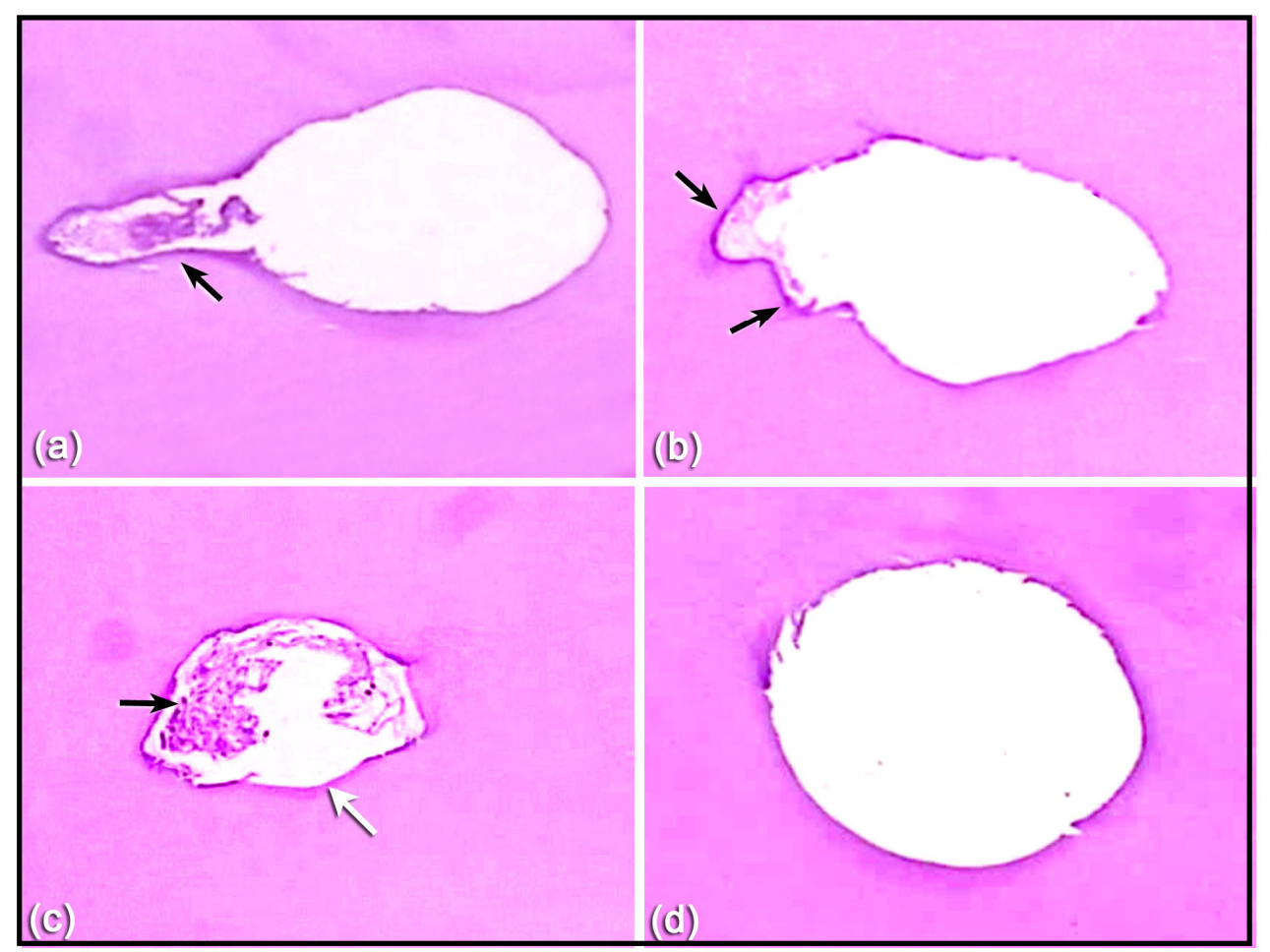

Figura 29. Fotomicrografias da região apical dos espécimes do grupo II, com aumento de 40X. Em (a), canal radicular apresentando achatamento acentuado de raiz com área (seta) em que o instrumento não tocou na parede (três instrumentos acima do IAI) com presença de débris; (b), canal radicular instrumentado com quatro instrumentos acima do IAI apresentando débris na região onde o instrumento não foi efetivo (setas); (c), canal radicular instrumentado por três instrumentos acima do IAI apresentando grande quantidade de débris na luz de seu canal (seta preta) e região onde o instrumento tocou nas paredes (seta branca); (d), canal radicular preparado com cinco instrumentos acima do IAI demonstrando ausência de débris e paredes preparadas praticamente em sua totalidade. 


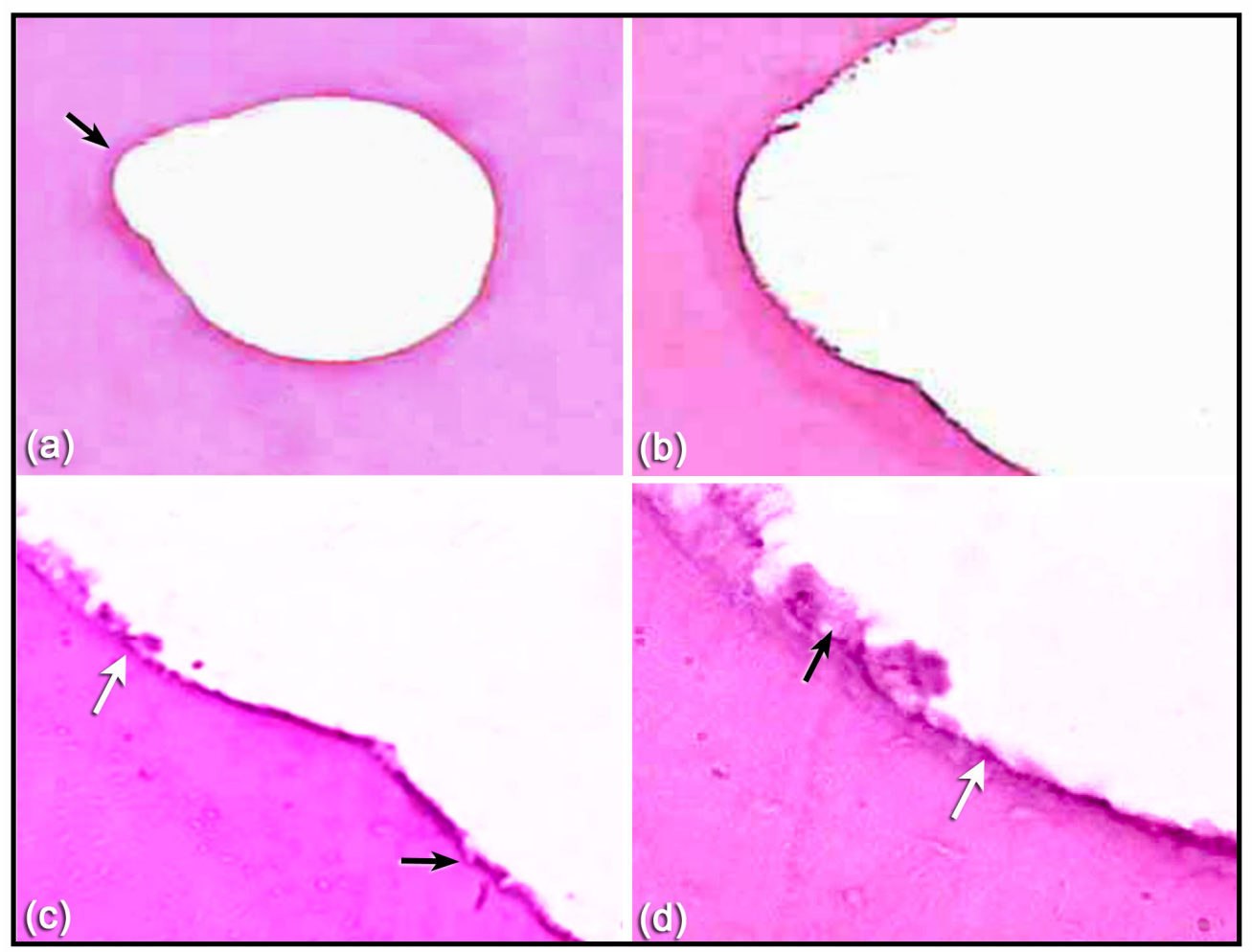

Figura 30. Fotomicrografias da região apical do espécime número 06 do grupo I, com aumento de 40X em (a), canal radicular apresentando achatamento de raiz com área (seta) em que o instrumento não tocou na parede (cinco instrumentos acima do IAI); (b), aumento de $100 \mathrm{X}$ apresentando mais detalhes da área não tocada pelo instrumento; (c), aumento de 400X, detalhes do limite entre a área instrumentada (seta preta) e a não tocada pelo instrumento (seta branca) e, (d), aumento de $1000 \mathrm{X}$, presença de débris (seta preta) e camada de pré-dentina (seta branca) na área em que o instrumento não tocou. 



\section{Discussão}


O tratamento endodôntico baseia-se na limpeza, preparo e desinfecção eficientes dos canais radiculares. Na busca contínua por melhores resultados várias técnicas, instrumentos e aparelhos têm sido desenvolvidos.

A complexa anatomia interna do sistema de canais radiculares e sua variação, quanto ao número e formato, merece especial atenção, principalmente nos casos de achatamento radicular, onde ocorrem áreas de difícil acesso, impedindo a realização do preparo e limpeza eficientes (BARBIZAN, et al., 2002; COHEN; BURNS, 1998; GRANDE et al., 2007; SASAKI et al., 2006; SEIXAS, et al., 2003; MARTOS et al., 2010; WU et al., 2000). Por isso, para a realização deste experimento foram selecionados incisivos inferiores.

O conhecimento do diâmetro anatômico apical do canal radicular, no comprimento de trabalho, é imprescindível para a limpeza eficiente das paredes do sistema endodôntico, pois a escolha do instrumento apical inicial acontece a partir desta medida. O modo mais aceito da determinação clínica do diâmetro anatômico, ainda é realizado pelo método tátil de inserção do instrumento que mais se adapta nas paredes dos canais radiculares (FIGDOR; SUNDQVIST, 2007; MARTOS et al., 2010).

A determinação in vitro do diâmetro anatômico apical tem sido muito pesquisada (BARROSO et al., 2005; IBELLI et al., 2007; PAQUÉ et al., 2010; PÉCORA et al., 2005; SCHMITZ et al 2008; VANNI et al., 2005; WU et al., 2000; WU et al., 2002). Os autores afirmam que o melhor resultado na seleção do instrumento apical inicial mostrou-se mais preciso quando o preparo cervical foi previamente realizado.

Assim, neste trabalho, o preparo cervical dos dentes foi realizado com brocas L.A. Axxess $^{\circledR}$, pela sua eficácia (BARROSO et al., 2005; IBELLI et al., 2007 PÉCORA et al., 2005; VANNI et al. 2005). 
Como o exame radiográfico apresenta informações limitadas, tanto da anatomia externa quanto interna dos elementos dentais in vivo, impossibilitando que seja feita, de forma precisa, medições dos canais radiculares, principalmente na região apical, vários estudos tem procurado uma metodologia que consiga aliar qualidade de imagem e segurança de análise (EDER et al., 2006; ESTRELA et al., 2008; LOW et al., 2008; PAULA-SILVA et al., 2009; PATEL, 2009; SBERNA et al., 2009).

Devido à busca de metodologia superior ao exame radiográfico, utilizou-se neste estudo a tomografia computadorizada que trás como vantagens entre outras: a possibilidade de medida da área apical e a visualização da morfologia interna dos canais radiculares em três planos (PAULA-SILVA et al., 2009; REUBEN et al., 2008), gerando imagens de qualidade superior em comparação aos outros métodos existentes (BERNARDES, et al., 2010; LOIZIDES, et al., 2007).

A escolha do aparelho de tomografia computadorizada cone beam, para a predeterminação da área apical dos canais radiculares no comprimento de trabalho, em detrimento a outros utilizados no diagnóstico médico, foi baseada em características vantajosas como: baixa dose de radiação, tempo reduzido para a realização dos exames, alta resolução e possibilidade da realização do exame com o paciente sentado (YAMASHINA et al., 2008), diminuindo a incidência de artefatos pela movimentação do paciente (PATEL et al., 2009).

No presente trabalho não foi encontrada diferença estatística significante entre os achados tomográficos e clínicos na determinação da área anatômica apical no comprimento de trabalho (p>0,05) (Tabela IV).

Por outro lado, comparando-se os resultados da mensuração das áreas dos canais radiculares instrumentados (área cirúrgica), pelo tomógrafo, com as áreas apicais dos 140 
instrumentos finais (instrumentos memória), clinicamente, verificou-se diferença estatística significante $(\mathrm{p}<0,001)$, sendo maiores os valores encontrados na metodologia clínica (Tabela IV).

A explicação para esses resultados deve-se às limitações dessa nova "ferramenta", que apresenta baixa resolução para imagens muito pequenas, além do que a irradiação secundária, gerada durante o processo radiográfico, cria uma área de penumbra em volta das estruturas. Estes fatos dificultam a visualização, com exatidão, mesmo com a utilização dos filtros presentes no software I Cat vision, dos limites das paredes dos canais radiculares tornando essa análise subjetiva e imprecisa.

Os resultados deste trabalho, são destoantes daqueles obtidos por Peters et al. (2000) e Somma et al. (2009), que estudaram a capacidade de análise do diâmetro e configurações da anatomia interna dos dentes por meio de Micro Tomógrafo Computadorizado. Este aparelho, em comparação com o Tomógrafo Computadorizado cone beam, apresenta como principal vantagem, melhor capacidade de definição de imagem devido a sua maior resolução. No entanto apresentam desvantagens no que se refere à análise de material in vivo, uma vez que possuem compartimento limitado para inserção de material, permitindo a analise laboratorial apenas de pequenas porções.

Outro fator importante para o sucesso da terapêutica endodôntica é a obtenção da limpeza e desinfecção dos canais radiculares. Para que esse processo se concretize, os canais devem ser alargados de modo que a irrigação e aspiração consigam penetrar o máximo possível, auxiliando de maneira efetiva o preparo na remoção de débris e da smear layer gerada na instrumentação (BOUTISIOUKIS, et al., 2010; BRONECC et al., 2010; BRUNSON et al., 2010; FIGDOR; SUNDQVIST, 2007; NAIR et al., 2005). 
Neste estudo avaliou-se, pela microscopia óptica com coloração H.E., a quantidade de débris encontrada no terço apical de canais preparados por instrumentos rotatórios mecanizados de NiTi, com três diferentes alargamentos apicais, irrigados por hipoclorito de sódio a 2,5\% de concentração, de modo hidrodinâmico (RinsEndo ${ }^{\circledR}$ ) ou pelo método convencional com seringa e agulha.

$\mathrm{O}$ preparo rotatório mecanizado com instrumentos de NiTi foi utilizado baseado em suas inúmeras vantagens salientadas em vários estudos (BERNARDES et al., 2010; ESPOSITO \& CUNNINGHAN, 1995; GAMBARINI, et al., 2002; GRANDE, et al., 2007; HULSMANN, et al., 2003; KUNERT, et al., 2010; PETERS, 2004), preparando melhor e em menor tempo, quando comparado com a instrumentação manual (BERNARDES et al., 2010; GUELZOW et al., 2005; PETERS, 2004).

A escolha da solução irrigante e sua concentração foram obtidas por suas características e vantagens em detrimentos de outras soluções (BRONECC et al., 2010; ESTRELA et al. 2002; SPANÓ et al., 2001), e pela necessidade de obtenção de rapidez na ação de dissolução e desinfecção dos tecidos.

A necessidade da obtenção de melhores resultados na limpeza levou os fabricantes a desenvolverem equipamentos que permitam diferentes modos de irrigação, auxiliando o preparo dos canais radiculares de forma mais eficiente.

Recentemente foi desenvolvido um sistema de irrigação hidrodinâmica (RinsEndo ${ }^{\circledR}$ ) prometendo melhores resultados em relação à limpeza no terço apical, e facilidade de utilização, quando comparados à metodologia convencional de irrigação.

Os resultados obtidos neste estudo demonstraram não haver diferença estatística significante entre as duas formas de irrigação aplicadas $(\mathrm{p}=0,73)$ (Tabela VIII). Observou-se que tanto o método convencional quanto o hidrodinâmico ou dinâmico automático pelo 142 
sistema RinsEndo ${ }^{\circledR}$ apresentaram resultados semelhantes com relação à quantidade de débris encontrada nos canais radiculares.

Semelhantes resultados foram encontrados nos estudos realizados por Vivan et al. (2010). No entanto, para Caron et al. (2010) e Rödig et al. (2010) a irrigação hidrodinâmica automática com o dispositivo RinsEndo ${ }^{\circledR}$ apresentou resultados inferiores quando comparados a outros modos de irrigação, contrariando os trabalhos de McGill et al. (2008) e Hauser, Braun e Frentzen (2007).

Pelos resultados obtidos neste estudo, o uso deste novo equipamento automático de irrigação parece ser injustificável, uma vez que seus resultados não superaram os do sistema convencional, e pela possibilidade de extrusão de material e, em casos de canais contaminados, como consequência a agudização do processo (Flare-up) (HAUSER; BRAUN; FRENTZEN, 2007).

A hipótese de que quanto maior o alargamento apical maior seria a limpeza promovida nas respectivas áreas, não foi confirmada no presente estudo.

Os resultados obtidos da limpeza promovida pelos diferentes níveis de alargamento não foram capazes de promover canais livres de débris, não apresentando diferença estatística significante $(\mathrm{p}=0,14)$ ( Tabela VIII).

A análise histológica do presente trabalho evidencia que os instrumentos não conseguiram um preparo efetivo de todas as paredes, deixando áreas intocadas pelos instrumentos, desfavorecendo a obtenção da limpeza efetiva dos canais radiculares. Este fato também foi salientado por Kereks e Tronstand (1977 a e b).

No presente estudo, várias paredes dos canais radiculares permaneceram intocadas demonstrando que, apesar do preparo ter sido realizado com cinco instrumentos acima do IAI, não se obteve a limpeza total (Figura 30 a). 
No entanto, a análise histológica das paredes dos canais, que foram tocadas pelos instrumentos, demonstrou haver diferenças estatísticas, entre os grupos testados, no que se refere aos diferentes alargamentos apicais $(\mathrm{p}<0,001)$ (Tabela XI). O preparo biomecânico com quatro (4) instrumentos acima do instrumento apical inicial determinou uma área de atuação significantemente superior ao mesmo preparo com apenas três (3) instrumentos, produzindo desta forma paredes instrumentadas e a remoção da camada de pré-dentina.

Por outro lado, comparando-se os grupos instrumentados com quatro (4) ou cinco (5) acima do IAI, não houve diferença estatística significante $(\mathrm{p}>0,05)$ (Tabela XI). Isso indica a necessidade de utilização de maiores alargamentos apicais, na tentativa de obtenção de melhores resultados na instrumentação de todas as paredes dos canais radiculares, levando-se em consideração o limite de instrumentação presente nos elementos dentais.

Resultado semelhante relacionado ao fato de os instrumentos não tocarem todas as paredes dos canais radiculares, devido ao formato das raízes e, portanto não apresentando resultado esperado na limpeza e obturação, foram observados também por várias outras pesquisas (BARBIZAN et al., 2002; FORNARI et al., 2010; FOSCHI et al., 2004; GRANDE et al., 2007; SEIXAS et al., 2003; SIQUEIRA JR et al., 2010; WU; WESSELINK, 2001).

O ideal seria que os instrumentos tocassem todas as paredes dos canais radiculares, e para isto o operador deveria saber quantos instrumentos deveriam ser utilizados. Esta possibilidade é, no momento, inviável clinicamente por diferentes razões tais como: variações anatômicas e possibilidade de causar desvios, perfurações e outras complicações. (CARD et al., 2002; COLDERO et al., 2002; FIGDOR; SUNDQVIST, 2007; HOCKETT et al., 2008; PETERS, 2004; SINGLA et al., 2010).

Neste trabalho verificou-se que a forma geométrica do canal radicular nos incisivos inferiores no comprimento de trabalho foi predominantemente elíptica, contrariando os 144 
achados de Martos et al. (2010) que encontraram predominância de canais com conformação circular na mesma região estudada.

Essa diferença de resultados pode ser explicada pela metodologia empregada na secção dos elementos dentais, pois, na presença de uma ligeira curvatura da raiz, se o corte não for realizado de forma perfeitamente perpendicular ao seu longo eixo, principalmente, nos casos de canais portadores de achatamento de raiz, a forma do canal pode apresentar-se circular ou elíptica (MIYASHITA, et al., 1997).

Este estudo abre novas perspectivas para elucidação de algumas dúvidas:

(a) quais aparelhos tomográficos, software de medida e técnicas apresentam resultados mais precisos na obtenção de informações da morfologia interna dos canais radiculares?

(b) quantos instrumentos acima do IAI seriam necessários para gerar limpeza apical mais eficiente e segura para a obtenção do sucesso endodôntico, uma vez que não houve diferença estatística significante de limpeza entre os alargamentos?

(c) novos instrumentos e sistemas de irrigação e aspiração, mais efetivos, poderiam resolver a questão da remoção dos resíduos gerados pelo preparo dos canais radiculares? 

Conclusões 

De acordo com a metodologia empregada e os resultados obtidos pode-se concluir:

1. A análise das áreas apicais com o Tomógrafo Computadorizado cone beam, não foi capaz de determinar de forma precisa as áreas apicais cirúrgicas em comparação ao método clínico, apresentando diferença estatística significante $(\mathrm{P}<0,001)$, sendo os maiores resultados observados nos métodos clínicos, por outro lado não foi demonstrada diferença estatística significante $(\mathrm{p}>0,05)$ entre as áreas anatômicas estudadas tanto por meio do método tomográfico, quanto clínico.

2. A limpeza da região apical dos canais radiculares no CT, instrumentada pelos diferentes níveis de alargamento não apresentou diferença estatística significante $(\mathrm{p}=0,14)$.

3. Tanto o método de irrigação convencional, quanto o hidrodinâmico (RinsEndo) não foram capazes de promover canais radiculares livres de débris, não apresentando diferença estatística significante $(\mathrm{p}=0,73)$.

4. A atuação dos instrumentos nas paredes dos canais radiculares foi diretamente proporcional ao número de instrumentos utilizados acima do instrumento apical inicial (IAI). 
Referências 
AGGARWAL, V; SINGLA, M.; LOGANI, A.; SHAH, N. Endodontic management of a maxillary first molar with two palatal canals with the AID of spiral Computed Tomography: A case report. J. Endod., Chicago, v.35, p.137-9, 2009.

ALBRECHT, L. J.; BAUMGARTNER, J. C.; MARSHALL, J. G. Evaluation of apical debris removal using various sizes and tapers of ProFile GT files. J. Endod., Chicago, v. 30, n. 6, p. 425-428, 2004.

BARATO-FILHO, F.; ZAITTER, S.; HARAGUSHIKU, GA.; DE CAMPOS, EA, ABUABRA, A.; CORRER, GM. Analysis of the internal anatomy of maxilary first molars by using different methods. J. Endod., Chicago v.35, n.3, p.337-42, 2009.

BARBIN, E. L. Estudo in vitro do efeito da adição de lauril dietilenoglicol éter sulfato de sódio nas soluções de hipoclorito de sódio sobre suas propriedades físico-químicas anteriores e posteriores à dissolução do tecido pulpar bovino. Ribeirão Preto, 1999, 108p. Dissertação (Mestrado) - Faculdade de Odontologia de Ribeirão Preto, Universidade de São Paulo.

BARBIZAN, J. V.; FARINIUK, L. F.; MARCHESAN, M. A.; PECORA, J. D.;SOUSANETO, M. D. Effectiveness of manual and rotary instrumentation techniques for cleaning flattened root canals. J. Endod., Chicago, v. 28, n. 5, p. 365-366, May 2002.

BARROSO, J. M.; GUERISOLI, D. M.; CAPELlI, A; SAQUY, P. C.; PECORA, J. D. Influence of cervical preflaring on determination of apical file size in maxillary premolars: SEM analysis. Braz. Dent. J., Ribeirão Preto, v. 16, n. 1, p. 30-34, Aug. 2005.

BAUGH, D.; WALLACE, J. The role of apical instrumentation in root canal treatment: a review of the literature. J. Endod., Chicago, v.31, n.5, p.333-40, 2005.

BECHELLI, C.; ORLANDI, S. Z.; COLAFRANCESCHI, M. Scanning electron microscope study on the efficacy of root canal wall debridament of hand versus Lightspeed instrumentation. Int. Endod. J., Oxford, n. 3, p. 484-93, 1999.

BERGMANS, L.; VANCLEYNENBREUGEL, J.; WEVERS, M.; LAMBRECHTS, P. A methodology for quantitative evaluation of root canal instrumentation using micro computed tomography. Int. Endod. J., Oxford, v.34, p.390-98, 2001. 
BERNARDES, R.A.; ROCHA, E.A.; DUARTE, M.A.H.; VIVAN, R.R.; MORAES, I.G.; BRAMANTE, A.S.; AZEVEDO, J.R. Root canal area increase promoted by the EndoSequence and ProTaper systems: Comparison by Computed tomography. J. Endod., Chicago, v.36, n. 7, p.1179-82, 2010.

BERTRAND, M. F.; PIZZARDINI, P.; MULLER, M.; MEDIONI, E.; ROCCA, J. P. The removal of the smear layer using the Quantec system. A study using the scanning electron microscope. Int. Endod. J., Oxford, v. 32, n. 3, p. 217-224, 1999.

BOUTSIOUKIS, C.; GOGOS, C.; VERHAAGEN, B.; VERSLUIS, M.; KASTRINAKIS, E.; VAN DER SLUIS, L.W.M. The effect of apical preparation size on irrigant flow in root canals evaluated using an unsteady Computational Fluid Dynamics model. Int. Endod. J., Oxford, v.43, p.874-81, 2010.

BRONNEC, F.; BOUILLAGUET, S.; MACHTOU, P. Ex vivo assessment of irrigant penetration and renewal during the cleaning and shaping of root canals: a digital subtraction radiographic study. Int.Endod. J., Oxford, v.43, p.275-282, 2010.

BRUNSON, M.; HEILBORN, C.; JOHNSON, D.J.; COHENCA, N. Effect of apical preparation size and preparation taper on irrigant volume delivered by using negative pressure irrigation system. J. Endod., Chicago, v.36, n.4, p.721-24, 2010.

CAMERON, J. A. The use of ultrasonics in the removal of smear layer: a scanning electron microscope study. J. Endod., Chicago, v. 9, n. 7, p. 289-292, 1983.

CAMERON, J. A. The choice of irrigant during hand instrumentation and ultrasonic irrigation of the root canal: a scanning electron microscopic study. Aust. Dent. J., Sydney, v. 40, n. 2, p. 85-90, 1995.

CARD, S. J.; SIGURDSSON, A.; ORSTAVIK, D.; TROPE, M..; The effectiveness of increased apical enlargement in reducing intracanal bacteria. J. Endod., Chicago, v. 28, n. 11, 779-783, Nov. 2002.

CARON, G.; NHAM, K.; BRONNEC, F.; MACHTOU, P. Effectiveness of different final irrigant activation protocols on smear layer removal in curved canals. J. Endod., Chicago, v.36, n.8, 2010. 
CHANDRA, S.S; RAJASEKARAN, M.; SHANKAR, P.; INDIRA, R. Endodontic management of a mandibular first molar with three distal canals confirmed with the aid of spiral computerized tomography: a case report. Oral Surg. Oral Med. Oral Pathol. Oral Radiol. Endod., St. Louis, v.108, n.4, p.77-81, 2009.

CHEUNG, L.H.M.; CHEUNG, G.S.P. Evaluation of a rotary instrumentation method for cshape canals with micro-computed tomography. J. Endod., Chicago, v.34, n.10, p.1233-38, 2008 .

CIVJAN, S.; HUGET, E.F.; De SIMON, L.B. Potencial applications of certain nickeltitanium (nitinol) alloys. J. Dent. Res., Chicago, v.54, n.1, p.89-96, 1975.

COLDERO, L.G.; McHUGH, S.; MacKENZIE, D.; SAUNDERS, W.P. Reduction in intracanal bacteria during root canal preparation with and without apical enlargement. Int. Endod. J., Oxford, v. 35, p. 437-446, 2002.

COHEN, S.; BURS, R.C. Pathways of the pulp. $7^{\text {th }}$ ed. St. Louis: Mosby, 1998.

DAI, L.; KHECHEN, K.; KHAN, S.; GILLEN, B.; LOSHINE, B.A.; WIMMER, C.E.; GUTMAN, J.L.; PASHEY, D.; TAY, F.R. The effect of Qmix, an experimental antibacterial root canal irrigant, on removal of canal wall smear layer and debris. J. Endod., Chicago, v.37, n.1, p.80-4, 2011.

DALL'AGNOL, C.; HARTMANN, M.S.M.; BARLETTA, F.B. Computed tomography assessment of the efficiency of different techniques for removal of root canal filling material. Braz. Dent. J., Ribeirão Preto, v.19, n.4, p.306-12, 2008.

DE DEUS, Q.D. Endodontia. 4 ed. Rio de Janeiro: Medsi, 1992.

DESAI, P.; HIMEL, V. Comparative safety of various intracanal irrigation systems. J. Endod., Chicago, n.35, n.4, p.545-49, 2009.

DOWKER, E.E.P.; DAVIS, G.R.; ELLIOTT, J.C. X-ray microtomography. Oral Surg. Oral Med. Oral Pathol. Oral Radiol. Endod., St. Louis, v.83, n.4, 1997. 
EDER, A.; KANTOR, M.; NELL, A.; MOSER, T.; GAHLEITNER, A.; SCHEDLE, A.; SPERR, W. Root canal system in the mesiobuccal root of the maxillary first molar: an in vitro comparison study of computed tomography and histology. Dentomaxilofac. Radiol. Suppl., Goteborg, v.35, p.175-77, 2005.

ESPOSITO, P.T.; CUNNINGHAM, C.J. A comparison of canal preparation with nickeltitanium and stainless steel instruments. J. Endod., Chicago, v.21, n.4, p.173-5, 1995.

ESTRELA, C.; ESTRELA, C. R. A.; BARBIN, E. L.; SPANÓ, J. C.; MARCHESAN, M. A.; PÉCORA, J. D. Mechanism of Action of Sodium Hypochlorite. Braz. Dent. J., Ribeirão Preto, v. 13, n. 2, p. 113-117, 2002.

ESTRELA, C.; BUENO, M.R.; LELES, C.R.; AZEVEDO, B.; AZEVEDO, J.R. Accuracy of Cone Beam Computed Tomography and Panoramic and Periapical Radiography for detection of apical periodontitis. J. Endod., Chicago, v.34, n.3, p.273-79, 2008a.

ESTRELA, C.; BUENO, M.R.; AZEVEDO, B.C.; AZEVEDO, J.R.; PÉCORA, J.D. A new periapical index based on cone beam computed tomography. J. Endod., Chicago, v.34, n.11, p.1325-31, 2008b.

FAN, B.; MIN, Y.; LU, G.; YANG, J.; CHEUNG, GS.; GUTMANN, JL. Negotiation of CShaped canal systems in mandibular second molars. J. Endod., Chicago, v.35, n.7, p.1003-8, 2009.

FARINIUK, L. F.; BARATTO-FILHO, F.; GUERISOLI, D. M. Z.; BARBIZAM, J. V. B.; PÉCORA, J. D.; SOUSA-NETO, M. D. Modeling capacity of ENDOflash files in simulated root canals. Braz. Dent. J., Ribeirão Preto, v.12, n.1, p.39-42, 2001.

FARINIUK, L.F.; BARATO-FILHO, F.;CRUZ-FILHO, A. M.; SOUSA -NETO, M.D. Histologic Analysis of the Cleaning Capacity of Mechanical Endodontic Instruments Activated by the Endoflash System. J. Endod., Chicago, v. 29, n. 10, p. 651-53, 2003.

FIGDOR, D.; SUNDQVIST, G. A big role for the very small-understanding the endodontic microbial flora. Austr. Dent. J., Sydney, v.52, p.38-51, 2007. 
FORNARI, V.J.; SILVA-SOUSA, Y.T.; VANNI, J.R.; PÉCORA, J.D.; VERSIANI, M.A.; SOUSA-NETO, M.D. Histological evaluation of effectiveness of increased apical enlargement for cleaning the apical third of curve canals. Int. Endod. J., Oxford, v.43, n.11, p.988-94, 2010.

FOSCHI, F.; NUCCI, C.; MONTEBUGNOLI, L.; MARCHIONNI, S.; BRESCHI, L.; MALAGNINO, V.A.; PRATI, C. SEM evaluation of canal wall dentine following use of Mtwo and ProTaper NiTi Rotary instruments. Int. Endod. J., Oxford, v.37, p.832-39, 2004.

GAMBARINI, G. Shaping and cleaning the root canal system: a scanning electron microscopic evaluation of a new instrumentation and irrigation technique. J. Endod., Chicago, v. 25, n. 12, p. 800-3, 1999.

GAMBARINI, G.; LASZKIEWICZ, J. A scanning electron microscopic study of debris and smear layer remaining following use of GT rotary instruments. Int. Endod. J., Oxford, v.35, n.5, p.422-427, 2002.

GAMBILL, J.M.; ALDER, M.; Del Rio, C.E. Comparison of nickel-titanium and stainless steel hand-file instrumentation using computed tomography. J. Endod., Chicago, v. 22, n.7, p.369-75, 1996.

GAO, Y.; PETERS, OA.; WU, H.; ZHOU, X. An application framework of three-dimensional reconstruction and measurement for endodontic research. J. Endod., Chicago, v.35, n.2, p.269-74, 2009.

GERGI, R.; RJEILY, J.A.; SADER, J.; NAAMAN, A. Comparison of canal transportation and centering ability of Twisted files, Pathfiles-ProTaper system, and stainless steel hand Kfile by using computed tomography. J.Endod., Chicago, v.36, n.5, p.904-907, 2010.

GLUSKIN, A.H.; BROWN, D.C.; BUCHANAN, L.S. A reconstructed computadorized tomographic comparison of $\mathrm{Ni}-\mathrm{Ti}$ rotary GT files versus traditional instruments in canals shaped by novice operators. Int. Endod. J., Oxford, v.34, p.476-84, 2001.

GRANDE, N.M.; PLOTINO, G.; BUTTI, A.; MESSINA, F.; PAMEIJER, C.H.; SOMMA, F. Cross-sectional analysis of root canals prepared with NiTi Rotary instruments and stainless steel reciprocating files. Oral Surg. Oral Med. Oral Pathol Oral Radiol. Endod., St. Louis, v.103, n.1, 2007. 
GRANDE, N.M.; PLOTINO, G.; PECCI, R.; BEDINI, R.; PAMEIJER, C. H.; SOMMA, F. Micro-computerized tomographic analysis of radicular and canal morphology of premolars with long oval canals. Oral Sug. Oral Med. Oral Pathol. Oral Radiol. Endod., St. Louis, v. 106, p.70-76, 2008.

GU, L.; KIM, J.R.; LING, J.; CHOI, K.K.; PASHELEY, D.H.; TAY, F.R. Review of contemporary irrigant agitation techniques and device. J. Endod., Chicago, v35, n.6, p.791$804,2009$.

GUELZOW, A.; STAMM, O.; MARTUS, P.; KIELBASSA, A.M. Comparative study of six rotary nickel-titanium systems and hand instrumentation for root canal preparation. Int. Endod. J., Oxford, v.38, n.10, p.743-52, 2005.

GUERISOLI, D. M. Z.; MARCHESAN, M. A.; WALMSLEY, P. J.; PÉCORA, J. D. Evaluation of smear layer removal by EDTAC and sodium hypochlorite with ultrasonic agitation. Int. Endod. J., Oxford, v. 35, n. 5, p. 418-421, 2002.

HAAPASALO, M.; ENDAL, U.; ZANDI, H.; COIL, J.M. Eradication of endodontic infection by instrumentation and irrigation solutions. Endodontic Topics, Hoboken, v.10, p.77-102, 2005.

HAMMAD, M.; QUALTROUGH, A.; SILIKAS, N. Three-dimensional evaluation of effectiveness of hand and rotary instrumentation for retreatment of canals filled with different materials. J. Endod., Chicago, v.34, n.11, p.1370-73, 2008.

HAUSER, V.; BRAUN, A.; FRENTZEN, M., Penetration depth of a dye marker into dentine using a novel hydrodynamic system (RinsEndo). Int. Endod. J., Oxford, v.40, p. 644-52, 2007.

HECKER, H.; BARTHA, T.; LOST, C.; WEIGER, R. Determination the apical preparation size in premolars: part III. Oral. Surg. Oral. Med. Oral Pathol. Oral. Radiol. Endod., St. Louis, v.110, n.1, p.118-124, 2010.

HOCKETT, J.L.; DOMIMISH, J.K.; JOHNSON, J.D.; COBENCA, N. Antimicrobial efficacy of two irrigation techniques in tapered and nontapered canal preparations: An in vitro study. J. Endod., Chicago, v.34, n.11, p.1374-77, 2008. 
HÜLSMANN, M.; SCHADE, M.; SCHÄFERS, F. A comparative study of root canal preparation with HERO 642 and Quantec SC rotary Ni-Ti instruments. Int. Endod. J., Oxford, v. 34, n. 7, p. 538-546, Oct. 2001.

HÜLSMANN, M.; GRESSMANN G.; SCHÄFERS, F. A comparative study of root canal preparation using FlexMaster and HERO 642 rotary Ni-Ti instruments. Int. Endod. J., Oxford, v. 36, n. 5, p. 358-366, May 2003.

IBELLI, G.S.; BARROSO, J.M.; SPANÓ, J.C.E.; PÉCORA, J.D. Influence of Cervical Preflaring on Apical File Size Determination in Maxillary Lateral Incisors. Braz. Dent. J., Ribeirão Preto, v.18, n. 2, 102-106, 2007.

KEREKS, K.; TRONSTAND, L. Morphometric observations on the root canals of human anterior teeth. J. Endod., Chicago, v.3, n.1, p.24-29, 1977 a.

KEREKS, K.; TRONSTAND, L. Morphometric observations on the root canals of human molars. J. Endod., Chicago, v.3, n.3, p.114-8, 1977 b.

KUNERT, G.G.; FONTANELLA, V.R.C.; MOURA, A.A.M.; BARLETTA, F.B. Analysis of apical root associated with ProTaper universal F3 and F4 instruments by using digital subtraction radiography. J. Endod., Chicago, v. 36, n. 6, p.1052-1055, 2010.

LA, S.H.; JUNG, D.H.; KIM, E.C.; MIN, K.S. Identification of independent middle mesial canal in mandibular first molar using cone-beam Computed Tomography imaging. J. Endod., Chicago, v.36, n.3, p.542-5, 2010.

LIEDKE, G.S.; SILVEIRA, H.E.D.; SILVEIRA, H.L.D.; DUTRA, V.; FIGUEIREDO, J.A.P. Influence of voxel size in the diagnostic ability of cone beam tomography to evaluate simulated external root resorption. J. Endod., Chicago, v.35, p.233-5, 2009.

LIMONGI, O.; ALBUQUERQUE, D. S.; BARATO FILHO, F.; VANNI, J. R.; OLIVEIRA, E. P. M.; BARLETTA, F. B. In vitro comparative study of manual and mechanical Rotary instrumentation of root canals using computed tomography. Braz. Endod. J., Ribeirão Preto, v.18, n.4, p.289-93, 2007. 
LOIZIDES, A. L.; KAKAVETSOS, V.D.; TZANETAKIS, G.N.; KONTAKIOTIS, E.G.; ELIADES, G. A comparative study of the effects of two nickel-titanium preparation techniques on root canal geometry assessed by micro computed tomography. J. Endod., Chicago, v.33, n.12, p.1455-9, 2007.

LOPES, H.P., SIQUEIRA JR, F.F. Endodontia: Biologia e Técnica. 2 ed., Rio de Janeiro., Medsi, 2004.

LOPEZ, F.V.; FACHIN, E.V.; FONTANELLA, V.R.; BARLETTA, F.B.; SÓ, M.V.R.; GUCCA, F.S. Apical transportation: A comparative evaluation of three root canal instrumentation techniques with three different apical diameters. J. Endod., Chicago, v.34, n.12, 2008.

LOW, K.M.; DULA, K.; BURGIGIN, W.; VON ARX, T. Comparison of periapical radiography and limited cone-beam tomography in posterior maxillary teeth referred for apical surgery. J. Endod., Chicago, v.34, n.5, p.557-62, 2008.

MADARATI, A. A.; QUALTROUGH, A. J. E.; WATTS, D. C. A Microcomputed Tomography scanning Study of root canal space: Changes after the ultrasonic removal of fractured files. J. Endod., Chicago, v.35, p.125-8, 2009.

MADER, C. L.; BAUMGARTNER, J. C.; PETERS, D. D. Scanning electron microscopic investigation of the smeared layer on root canal walls. J. Endod., Chicago, v. 10, n. 10, p. 477-483, 1984.

MAHRAN, A.H.; ABOEL-FOTOUH, M.M. Comparison of effects of ProTaper, Hero shaper, and Gates Glidden burs on cervical dentin thickness and root canal volume by using Multislice Computed Tomography. J. Endod., Chicago, v.34, n.10, p.1219-22, 2008.

MARCHESAN, M. A.; ARRUDA, M. P.; SILVA-SOUSA, Y. T. C; SAQUY, P. C.; PECORA, J. D.; SOUSA-NETO, M. D. Morphometrical analysis of cleaning capacity using nickel - titanium rotary instrumentation associated with irrigating solutions in mesio-distal flattened root canals. J Appl Oral Sci., Bauru, v. 11, n. 1, p. 55-59, 2003.

MARTIN, H.; CUNNINGHAM, W. T. The effect of endosonic and hand manipulation on the around of root canal material extruded. Oral Surg. Oral Med. Oral Pathol., St. Louis, v. 53, n. 6, p. 611-613,1982. 
MARTOS, J.; LUBIAN, C.; SILVEIRA, L.F.M.; CASTRO, L.A.S.; LUQUE, M.F. Morphologic Analysis of the root apex in human teeth. J. Endod., Chicago, v.36, n.4, p.664667, 2010.

McCOMB, D.; SMITH, D. C. A preliminary scanning electron microscopic study of root canals after endodontic procedures. J. Endod., Chicago, v. 1, n. 7, p. 238-242, 1975.

McGILL, S.; GULABIVALA, K.; MORDAM, N.; NG, Y.L. The efficacy of dynamic irrigation using a commercially available system (RinsEndo) determined by removal of a collagen bio-molecular film from an ex vivo model. Int. Endod. J., Oxford, v.41, p.602-608, 2008.

MENNOCCI, F.; PERU, M.; SHERRIF, M.; COOK, R.; PITT FORD, T.R. The isthmuses of the mesial root of mandibular molars: a micro-computed tomographic study. J. Endod., Chicago, v.38, n.8, p.558-63, 2005.

METZGER, Z.; TEPEROVICH, E.; ZARY, R.; COHEN, R.; HOF, R. The Self-adjusting file (SAF). Part 1: Respecting the root canal anatomy - A new concept of Endodontic files and its implementation. J. Endod., Chicago, v.36, n.4, p.679-90, 2010.

MILLER, T.A.; BAUMGARTNER, J.C. Comparison of the antimicrobial efficacy of irrigation using the EndoVac to endodontic needle delivery. J. Endod., Chicago, v.36, p.509$11,2010$.

MIYASHITA, M.; KASAHARA, E.; YASUDA, E.; YAMAMOTO, A.; SEKIZAWA, T. Root canal system of the mandibular incisor. J. Endod., Chicago, v.23, n.8, p.479-84, 1997.

MOODNIK, R. M..; DORN, S.O.; FELDMAN, M.J.; LEVEY, M.; BORDEN, B.O. Efficacy of Biomechanical instrumentation: a scanning electron microscopic study. J. Endod., Chicago, v.2, n. 9, p. 261-6, sept 1976.

MOORER, W. R.; WESSELINK, P. R. Factors promoting the tissue dissolving capability of sodium hypochlorite. Int. Endod. J., Oxford, v. 15, n. 4, p. 187-196, 1882. 
MOREIRA, C. R.; SALES, M. A. O.; LOPES, P. M. L.; CAVALCANTI, M. G. P. Assessment of linear and angular measurements on three dimensional cone-beam computed tomographic images. Oral Surg. Oral Med. Oral Pathol Oral Radiol. Endod., St. Louis, v.108, p.430-36, 2009.

MUNLEY, P. J.; GOODELL, G. G. Comparison of passive ultrasonic debridement between fluted and no fluted instruments in root canals. J. Endod., Chicago, n.33, p.578-80, 2007.

NADALIN, M.R., Análise histológica e morfométrica do terço apical de canais radiculares achatados após remoção de "débris" utilizando diferentes protocolos de irrigação final. Ribeirão Preto, 2005, 132p. Dissertação (Mestrado) - Faculdade de Odontologia de Ribeirão Preto, Universidade de Ribeirão Preto.

NAIR, P.N.R.; HENRY, S.; CANO, V.; VERA, J. Microbial status of apical root canal system of human mandibular first molar with primary apical periodontitis after "one-visit" endodontic treatment. Oral Surg. Oral med. Oral Pathol Oral Radiol. Endod., St. Louis, v.99, p.231-52, 2005.

PAQUÉ, F.; MUSCH, U.; HULSMANN, M. Comparison of root canal preparation using RaCe and ProTaper rotary Ni-Ti instruments. Int. Endod. J., Oxford, v.38, n.1, p.8-16, 2005.

PAQUÉ, F.; GANAHL, D.; PETERS, O. A. Effects of root canal preparation on apical geometry assessed by micro-computed tomography. J. Endod., Chicago, v.35, n.7, p.1056-9, 2009.

PAQUÉ, F.; LAIB, A., GAUTSCHI, H.; ZEHNDER, M. Hard-tissue debris accumulation analysis by high-resolution Computed Tomography Scans. J. Endod., Chicago, v.35, p.104447, 2009.

PAQUÉ, F,; ZEHNDER, M.; MARENDING, M. Apical fit of initial K-files in maxillary molars assessed by micro-computed tomography. Int. Endod. J., Oxford, v.43, p.328-35, 2010.

PASSARINHO-NETO, J. G.; MARCHESAN, M. A.; FERREIRA, R. B.; SILVA, R. G.; SILVA-SOUSA, Y. T. C.; SOUSA-NETO, M. D. In vitro evaluation of endodontic débris removal as obtained by rotary instrumentation coupled with ultrasonic irrigation. Aust. Endod. J., Melbourne, v. 32, p. 123-128, 2006. 
PATÉL, S. New dimensions in endodontic imaging: Part 2. Cone beam computed tomography. Int. Endo. J., Oxford, v.42, p.463-75, 2009.

PAULA-SILVA, F.W.G.; WU, M.K.; LEONARDO, M.R.; DA SILVA, L.A.B.; WESSELINK, P.R. Accuracy of periapical radiography and Cone-beam Computed Tomography Scans in diagnosing apical periodontitis using histopathological findings as a gold standard. J. Endod., Chicago, v.35, n.7, p.1009-12, 2009.

PÉCORA, J. D.; SAQUY, P. C.; SOUSA NETO, M. D.; WOELFEL, J. B. Root form and canal anatomy of maxillary first premolars. Braz. Dent. J., Ribeirão Preto, v. 2, n. 2, p. 8794, Jul.-Dec. 1992.

PÉCORA, J. D.; CAPELLI, A.; SEIXAS, F. H.; MARCHESAN, M. A, GUERISOLI, D. M. Z. Biomecânica Rotatória: Realidade ou Futuro? Rev. Ass. Paul. Cir. Dent., São Paulo, v. 56, n. 3, p. 4-6, Jun. 2002.

PÉCORA J. D.; CAPELli, A.; GUERISOLI, D. M. Z.; SPANÓ, J. C. E.; ESTRELA, C. Influence of cervical preflaring on apical file size determination. Int. Endod. J., Oxford, v. 38, n. 7, p. 430-435, Jul. 2005.

PETERS, O.A.; LAIB, A.; RÜEGSSEGER, P.; BARBAKOW, Three-dimensional analysis of root canal geometry by high-resolution computed tomography. J. Dent. Res., Chicago, v 79, n. 6, p. 1405-1409, 2000.

PETERS, O.A.; SCHÖNENBERGER, K.; LAIB, A. Effects of four Ni-Ti preparation techniques on root canal geometry assessed by micro computed tomography. Int. Endod. J., Oxford, v.34, n.3, p.221-30, 2001.

PETERS, O.A.; LAIB, A; GOHRING, T.N.; BARBAKOW, F. Changes in root canal geometry after preparation assessed by high-resolution computed tomography. J. Endod., Chicago, v.27, n.1, p.1-6, 2001.

PETERS, O.A.; PETERS, C.I.; SCHÖNENBERGER, K.; BARBAKOW, F. ProTaper rotary root canal preparation: effects of canal anatomy on final shape analyzed by micro CT. Int. Endod. J., Oxford, v.36, n.2, p.86-92, 2003.

PETERS, O.A.; PETERS, C.I.; SCHÖNENBERGER, K.; BARBAKOW, F. ProTaper rotary root canal preparation: assessment of torque and force in relation to canal anatomy. Int. Endod. J., Oxford, v36, n.2, p.93-9, 2003. 
PETERS, O. A. Current challenges and concepts in the preparation of root canal systems: A review. J. Endod., Chicago, v.30, n.8, 2004.

PETERS, O. A.; BARBAKOW, F.; PETERS, C. L. An analysis of endodontic treatment with three nickel-titanium rotary root canal preparation techniques. Int. End. J., Oxford, v.37, n.12, p.849-59, 2004.

PETERS, O. A.; BOESSLER, C.; PAQUÉ, F. Root canal preparation with a novel nickeltitanium instrument evaluated with Micro-computed Tomography: Canal Surface Preparation over Time. J. Endod., Chicago, v36, p.1068-72, 2010.

REUBEN, J.; VELMURUGAN, N.; KANDASWAMY, D. The evaluation of root canal morphology of the mandibular first molar in an Indian population using spiral computed tomography scan: an in vitro study. J. Endod., Chicago, v.34, n.2, p.212-5, 2008.

RICHMAN, M. J. Use of ultrasonic in root canal therapy and root resection. J. Dent. Med., New York, v. 12, n. 1, p. 12-18, 1957.

RICUCCI, D.; BERGENHOLTZ, G. Bacterial status in root-filled teeth exposed to the oral environment by loss of restoration and fracture or caries-a histobacteriological study of treated cases. Int. Endod. J., Oxford, v. 36, n.11, p.787-802, 2003.

RHODES, J. S.; PITT FORD, T. R.; LYNCH, J. A.; LIEPINS, P. J.; CURTIS, R. V. A comparison of two nickel-titanium instrumentation techniques in teeth using micro computed tomography. Int. Endod. J., Oxford, v.33, p.279-85, 2000.

RÖDIG, T.; HÜLSMANN, M.; MÜHGE, M.; SCHÄFERS, F. Quality of preparation of oval distal root canals in mandibular molars using nickel-titanium instruments. Int. Endod. J., Oxford, v. 35, n. 11, p. 919-928, 2002.

RÖDIG, T.; SEDGHI, M.; KONIETSCHKE, F.; LANGE, K.; ZIEBOLZ, D.; HULSMANN, M. Efficacy of syringe irrigation, RinsEndo and passive ultrasonic irrigation in removing debris from irregularities in root canals with different apical sizes. Int. Endod. J., Oxford, v.43, p.581-89, 2010.

SABET, N. E.; LUTFY, R. A. Ultra structural morphologic evaluation of root canal walls prepared by two rotary x nickel-titanium systems: a comparative study. Oral. Surg.Oral Med. Oral Pathol. Oral Radiol. Endod., St. Louis, v.106, n.3, p.59-66, 2008. 
SABINS, R. A.; JOHNSON, D.; HELLSTEIN, J. W. A comparison of the cleaning efficacy of short-term sonic and ultrasonic passive irrigation after hand instrumentation in molar root canals. J. Endod., Chicago, v.29, n.10, p. 674-78, 2003.

SANFELICE, C. M.; COSTA, F. B.; SÓ, M. V. R.; VIER-PELISSER, F.; BIER, C. A. S.; GRECCA, F. S. Effects of four instruments on coronal pré-enlargement by using cone beam computed tomography. J. Endod., Chicago, v.35, n.5, p.858-861, 2010.

SASAKI, E. W.; VERSIANI, M. A.; PEREZ, D. E. C.; SOUSA-NETO, M. D.; SILVASOUSA, Y. T. C.; SILVA, R. G. Ex vivo analysis of the debris remaining in flattened root canals of vital and nonvital teeth after biomechanical preparation with Ni-Ti rotary instruments. Braz. Dent. J., Ribeirão Preto, v.17, n.3, p. 233-236, 2006.

SBERNA, M. T.; RIZZO, G. ZACCHI, E.; CAPPARE, P. RUBINACCI, A. A preliminary study of the use of peripheral quantitative computed tomography for investigating root canal anatomy. Int. Endod. J., Oxford, v.42, p.66-75, 2009.

SCHÄFER, E.; LOHMANN, D. Efficiency of rotary nickel-titanium FlexMaster instruments compared with stainless steel hand K-Flexofile. Shaping ability in simulated curved canals. Int. Endod. J., Oxford, v. 35, n. 6, p. 505-513, Jun. 2002a.

SCHÄFER, E.; LOHMANN, D. Efficiency of rotary nickel-titanium FlexMaster instruments compared with stainless steel hand K-Flexofile. Cleaning effectiveness and instrumentation results in severely curved root canals of extracted teeth. Int. Endod. J., Oxford, v. 35, n. 6, p. 514-521, Jun. 2002b.

SCHÄFER, E.; VLASSIS, M. Comparative investigation of two rotary nickel titanium instruments: ProTaper versus RaCe. Part 2. Cleaning effectiveness and shaping ability in severely curved root canals of extracted teeth. Int. Endod. J., Oxford, v. 37, p. 239-248, 2004.

SCHILDER, H. Cleaning and shaping the root canal. Dent. Clin. North Am., Philadelphia, v.18, n. 2, p. 268-296, Apr. 1974.

SCHMITZ, M. S.; SANTOS, R.; CAPELLI, A.; JACOBOVITZ, M.; SPANO, J. C. E.; PÉCORA, J. D. Influence of cervical preflaring on determination of apical file size in mandibular molars: SEM analysis. Braz. Dent. J., Ribeirão Preto, v.19, n.3, p.245-51, 2008. 
SEIXAS, F. H.; BRUGNERA JR, A.; SILVA, R.G.; CAPELLI, A.; GUERISOLI, D. M. Z.; PÉCORA, J. D. Er: YAG laser evaluation of smear layer removal from flattened root canals submitted to rotary instrumentation. Lasers in Dentistry, San Jose, v. 4, n. 2, p.177-85, 2003.

SEM, B. H. The smear layer: A phenomenon root canal therapy. Int. Endod. J., Oxford, v. 28, p. 141-8, 1995.

SETLOCK, J.; FAYAD, M, I.; BEGOLE, E.; BRUZICK, M. Evaluation of canal cleanliness and smear layer removal after the use of the Quantec-E irrigation system and syringe: A comparative scanning electron microscope study. Oral Surg. Oral Med. Oral Pathol. Oral Radiol. Endod. St. Louis, v. 96, p. 614-7, 2003.

SHEN, Y.; HAAPSALO, M. Three-dimensional analysis of cutting behavior of nickeltitanium rotary instruments by micro computed tomography. J. Endod., Chicago, v.34, n.5, p.606-10, 2008.

SHIN, S. J.; KIM, H. K.; JUNG, I. Y.; LEE, C. Y.; LEE, S. J.; KIM, E. Comparison of the cleaning efficacy of a new apical negative pressure irrigation system with conventional irrigation needles in the root canals. Oral Med. Oral Pathol. Oral Radiol. Endod., St. Louis, v.109, p.479-84, 2010.

SINGLA, M.; AGGARWAL, V.; LOGANI, A.; SHAH, N. Comparative evaluation of Rotary ProTaper, ProFile, and conventional step back technique on reduction in Enterococcus Faecalis colony-forming units and vertical root fracture resistance of root canals. Oral Med. Oral Pathol. Oral Radiol. Endod., St. Louis, v. 109, p.105-110., 2010.

SIQUEIRA, J. F. Jr.; ARAUJO, M. C.; GARCIA, P. F.; FRAGA, R. C.; DANTAS, C. J. Histological evaluation of the effectiveness of five instrumentation techniques for cleaning the apical third of root canals. J. Endod., Chicago, v. 23, n. 8, p. 499-502, Aug. 1997.

SIQUEIRA, J.F.JR.; ALVES, F.R.F.; ALMEIDA, B.M.; OLIVEIRA, J.C.M.; RÔÇAS, I.N. Ability of chemomechanical preparation with either rotary instruments or Self-adjusting File to disinfect oval-shaped root canals. J. Endod., Chicago, v.36, p.1860-65, 2010. 
SOMMA, F.; LEONI, D.; PLOTINO, G.; GRANDE, N.M.; PLASSCHAERT, A. Root canal morphology of the mesiobuccal root of maxilary first molars: a micro-computed tomographic analysis. Int. Endod. J., Oxford, v.42, p.165-74, 2009.

SPANÓ, J. C. E.; BARBIN, E. L.; SANTOS, T. C.; GUIMARÃES, L. F.; PÉCORA, J. D. Solvent action of sodium hypochlorite on bovine pulp and physicochemical properties of resulting liquid. Braz Dent. J., Ribeirão Preto, v. 12, n. 3, p. 154-179, 2001.

SPONCHIADO, E. C. JR.; ISMAIL, H. A.; BRAGA, M. R.; DE CARVALHO, F. K., SIMÕES, C. A. Maxillary central incisor with two root canals: a case report. J. Endod., Chicago, v.32, n.10, p.1002-4, 2006.

STEVEN, J. C.; SIGURDSSON, A.; ORSTAVIK, D; TROPE, M. the effectiveness of increased apical enlargement in reducing intracanal bacteria. J. Endod., Chicago, v. 28, n. 11, p.779-783, 2002.

TACHIBANA, H.; MATSUMOTO, K. Application of X-ray computerized tomography in endodontics. Endod. Dent. Traumatol., Copenhagen, v.6, n.1, p.16-20, 1990.

TAN, T. B.; MESSER, H. H. The quality of apical canal preparation using hand and rotary instruments with specific criteria for enlargement based on initial apical file size. J. Endod., Chicago, v. 28, n. 9, p. 658-64, 2002.

TOWNSEND, C.; MAKI, J. An in vitro comparison of new irrigation and agitation techniques to ultrasonic agitation in removing bacteria from a simulated root canal. $\mathbf{J}$. Endod., Chicago, v.35, n.7, 2009.

USMAN, N.; BAUMGARTNER, J. C; MARSHALL, J. G. Influence of instrument size on root canal debridement. J. Endod., Chicago, v. 30, n. 2, p. 110-112, 2004.

VANDER SLUIS, L.W.M.; WU, M.K.; WESSELINK, P.R. The evaluation of removal of calcium hydroxide paste from an artificial standardized groove in the apical root canal using different irrigation methodologies. Int. Endo. J., Oxford, n.40, p.52-57, 2007.

VANDER SLUIS, L.W.M.; VERSLUIS, M.; WU, M.K.; WESSELINK, P.R. Passive ultrasonic irrigations of the root canal: A review of the literature. Intern. Endod. J., Oxford, v.40, p. 415-426, 2007. 
VANNI, J. R.; SANTOS, R.; LIMONGI, O.; GUERISOLI, D. M. Z.; CAPELLI, A.; PÉCORA, J. D. Influence of cervical preflaring on determination of apical file size in maxilar molars: SEM analysis. Braz. Dent. J., Ribeirão Preto, v.16, n.3, p.181-6, 2005.

VELTRI, M.; MOLLO, A.; MANTOVANI, L.; PINI, P.; BALLERI, P.; GRANDINI, S. A comparative study of EndoFlare-Hero Shaper and Mtwo NiTi instruments in the preparation of curved root canals. Int. Endod. J., Oxford, v.38, n.9, p.610-6, 2005.

VIVAN, R. R.; BORTOLO, M. V.; DUARTE, M. A. H.; MORAES, I. G.; TANOMARUFILHO, M.; BRAMANTE, C. M. Scanning electron microscopy analysis of RinsEndo system and conventional irrigation for débris removal. Braz. Dent. J., Ribeirão Preto, v.21, n.4, p.305-9, 2010.

WALIA, H.; BRANTLEY, W.A.; GERSTEIN, H. An initial investigation of the bending and torsional properties of nitinol root canal files. J. Endod., Chicago, v.14, n.7, p.346-51, 1988.

WALTERS, M. J; BAUMGARTNER, J. C.; MARSHALL, J. G. Efficacy of Irrigation with Rotary Instrumentation. J. Endod., Chicago, v. 28, n. 12, p. 837-839, 2002.

WALTON, R. E. Histologic evaluation of different methods of enlarging the pulp canal space. J. Endod., Chicago, v.2, p. 304-11, 1976.

WANG, Y.; ZHENG, Q.; ZHOU, X.; TANG, L.; WANG, Q.; ZHENG, G.; HUANG, D. Evaluation of the root canal morphology of mandibular first permanent molars in a western Chinese population by cone-beam Computed Tomography. J. Endod., Chicago, v.36, n.11, p.1786-89, 2010.

WEBER, C. D.; McCLANAHAN, S. B.; MILLER, G. A.; DIENER-WEST, M.; JOHNSON, J. D. The effect of passive ultrasonic activation of $2 \%$ clorhexidine or $5,25 \%$ sodium hypochlorite irrigant on residual antimicrobial activity in root canals. J. Endod., Chicago, v.29, n.9, 2003.

WILlIAMSON, A. E.; SANDOR, A. J.; JUSTMAN, B. C. A comparison of three nickel titanium rotary systems, EndoSequence, ProTaper Universal, and ProFile GT, for canalcleaning ability. J. Endod., Chicago, v.35, n.1, 2009. 
WU, M. K.; R'ORIS, A.; BARKIS, D.; WESSELINK, P. R. Prevalence and extent of long oval canals in the apical third. Oral Surg. Oral Med. Oral Pathol. Oral Radiol Endod., St. Louis, v.89, p.739-43, 2000.

WU, M. K.; WESSELINK, P. R. A primary observation on the preparation and obturation of oval canals. Int. Endod. J., Oxford, v.34, n.2, p.137-41, 2001.

WU, M. K.; BARKIS, D.; RORIS, A.; WESSELINK, P. R. Does the first file to bind correspond to the diameter of the canal in the apical region? Intern. Endod. J., Oxford, v.35, n.3, p.264-267, 2002.

YAMASHINA, A.; TANIMOTO, K.; SUTTHIPRAPAPORN, P; HAYAKAWA, Y. The reliability of computed tomography $(\mathrm{CT})$ values and dimensional measurements of the oropharyngeal region using cone beam CT: comparison with multidetector CT. Dentomaxilofac. Radiol. Suppl., Goteborg, v.37, p.245-51, 2008.

YARED, G. M.; BOU DAGHER, F. E. Influence of apical enlargement on bacterial infection during treatment of apical periodontitis. J. Endod., Chicago, v. 20, p. 535-7, 1994.

ZELTENER, M.; PETERS, O. A; PAQUÉ, F. Temperature changes during ultrasonic irrigation with different inserts and modes of activation. J. Endod., Chicago, v.35, n.4, 2009. 
Apêndice 
Tabela das áreas $\left(\mathrm{mm}^{2}\right)$ dos espécimes antes da instrumentação (Anatômico)

\begin{tabular}{|c|c|c|c|}
\hline Dentes & Examinador 1 & Examinador 2 & Examinador 3 \\
\hline 1 & 0,04 & 0,04 & 0,04 \\
\hline 2 & 0,03 & 0,03 & 0,03 \\
\hline 3 & 0,08 & 0,08 & 0,08 \\
\hline 4 & 0,06 & 0,05 & 0,05 \\
\hline 5 & 0,02 & 0,02 & 0,02 \\
\hline 6 & 0,08 & 0,1 & 0,08 \\
\hline 7 & 0,04 & 0,04 & 0,03 \\
\hline 8 & 0,04 & 0,04 & 0,03 \\
\hline 9 & 0,04 & 0,02 & 0,02 \\
\hline 10 & 0,04 & 0,03 & 0,03 \\
\hline 11 & 0,05 & 0,06 & 0,06 \\
\hline 12 & 0,05 & 0,04 & 0,04 \\
\hline 13 & 0,02 & 0,02 & 0,02 \\
\hline 14 & 0,03 & 0,03 & 0,02 \\
\hline 15 & 0,06 & 0,06 & 0,06 \\
\hline 16 & 0,05 & 0,05 & 0,05 \\
\hline 17 & 0,03 & 0,03 & 0,03 \\
\hline 18 & 0,1 & 0,08 & 0,09 \\
\hline 19 & 0,06 & 0,06 & 0,06 \\
\hline 20 & 0,08 & 0,07 & 0,08 \\
\hline 21 & 0,09 & 0,08 & 0,08 \\
\hline 22 & 0,04 & 0,05 & 0,04 \\
\hline 23 & 0,04 & 0,04 & 0,04 \\
\hline 24 & 0,05 & 0,04 & 0,04 \\
\hline 25 & 0,03 & 0,02 & 0,03 \\
\hline 26 & 0,05 & 0,05 & 0,04 \\
\hline 27 & 0,02 & 0,02 & 0,02 \\
\hline 28 & 0,03 & 0,03 & 0,03 \\
\hline 29 & 0,05 & 0,05 & 0,05 \\
\hline 30 & 0,04 & 0,04 & 0,04 \\
\hline 31 & 0,03 & 0,02 & 0,02 \\
\hline 32 & 0,03 & 0,03 & 0,02 \\
\hline 33 & 0,08 & 0,09 & 0,09 \\
\hline 34 & 0,03 & 0,02 & 0,03 \\
\hline 35 & 0,08 & 0,08 & 0,08 \\
\hline 36 & 0,09 & 0,09 & 0,09 \\
\hline 37 & 0,04 & 0,03 & 0,04 \\
\hline 38 & 0,08 & 0,08 & 0,08 \\
\hline 39 & 0,03 & 0,03 & 0,03 \\
\hline 40 & 0,02 & 0,02 & 0,02 \\
\hline 41 & 0,03 & 0,03 & 0,03 \\
\hline 42 & 0,05 & 0,05 & 0,05 \\
\hline
\end{tabular}


Tabela das áreas $\left(\mathrm{mm}^{2}\right)$ dos espécimes após a instrumentação (Cirúrgico)

\begin{tabular}{|c|c|c|c|}
\hline Dentes & Examinador 1 & Examinador 2 & Examinador 3 \\
\hline 1 & 0,10 & 0,10 & 0,10 \\
\hline 2 & 0,07 & 0,08 & 0,07 \\
\hline 3 & 0,13 & 0,16 & 0,15 \\
\hline 4 & 0,14 & 0,13 & 0,14 \\
\hline 5 & 0,08 & 0,08 & 0,08 \\
\hline 6 & 0,21 & 0,20 & 0,21 \\
\hline 7 & 0,09 & 0,07 & 0,08 \\
\hline 8 & 0,11 & 0,10 & 0,10 \\
\hline 9 & 0,11 & 0,10 & 0,11 \\
\hline 10 & 0,08 & 0,07 & 0,07 \\
\hline 11 & 0,10 & 0,09 & 0,10 \\
\hline 12 & 0,11 & 0,10 & 0,10 \\
\hline 13 & 0,12 & 0,12 & 0,11 \\
\hline 14 & 0,18 & 0,16 & 0,17 \\
\hline 15 & 0,15 & 0,16 & 0,14 \\
\hline 16 & 0,12 & 0,13 & 0,12 \\
\hline 17 & 0,12 & 0,12 & 0,12 \\
\hline 18 & 0,13 & 0,13 & 0,13 \\
\hline 19 & 0,11 & 0,11 & 0,10 \\
\hline 20 & 0,08 & 0,09 & 0,08 \\
\hline 21 & 0,18 & 0,17 & 0,17 \\
\hline 22 & 0,12 & 0,10 & 0,14 \\
\hline 23 & 0,12 & 0,11 & 0,12 \\
\hline 24 & 0,17 & 0,16 & 0,18 \\
\hline 25 & 0,09 & 0,09 & 0,10 \\
\hline 26 & 0,11 & 0,09 & 0,11 \\
\hline 27 & 0,10 & 0,10 & 0,10 \\
\hline 28 & 0,15 & 0,13 & 0,14 \\
\hline 29 & 0,11 & 0,11 & 0,11 \\
\hline 30 & 0,11 & 0,10 & 0,11 \\
\hline 31 & 0,09 & 0,08 & 0,09 \\
\hline 32 & 0,15 & 0,13 & 0,15 \\
\hline 33 & 0,15 & 0,14 & 0,16 \\
\hline 34 & 0,10 & 0,10 & 0,10 \\
\hline 35 & 0,13 & 0,11 & 0,13 \\
\hline 36 & 0,11 & 0,10 & 0,12 \\
\hline 37 & 0,08 & 0,08 & 0,08 \\
\hline 38 & 0,11 & 0,10 & 0,12 \\
\hline 39 & 0,12 & 0,11 & 0,12 \\
\hline 40 & 0,07 & 0,06 & 0,07 \\
\hline 41 & 0,11 & 0,10 & 0,11 \\
\hline 42 & 0,18 & 0,16 & 0,17 \\
\hline
\end{tabular}


Os valores abaixo foram adquiridos segundo as limas que se adaptaram nas paredes dos canais radiculares no comprimento de trabalho dos elementos estudados.

Valores dos instrumentos iniciais das amostras (clínico)

\begin{tabular}{lllllll}
\hline 25 & 30 & 30 & 25 & 30 & 25 & 25 \\
25 & 20 & 30 & 25 & 25 & 25 & 40 \\
30 & 30 & 25 & 30 & 30 & 35 & 30 \\
25 & 20 & 20 & 20 & 30 & 20 & 20 \\
25 & 25 & 25 & 20 & 20 & 20 & 30 \\
20 & 20 & 25 & 25 & 30 & 20 & 35 \\
\hline
\end{tabular}

Média $=25 \pm 4.93$

Valores dos diâmetros cirúrgicos das amostras (clínico)

\begin{tabular}{lllllll}
\hline 55 & 60 & 55 & 45 & 50 & 55 & 55 \\
50 & 45 & 45 & 40 & 50 & 40 & 45 \\
40 & 45 & 40 & 40 & 45 & 45 & 40 \\
60 & 45 & 55 & 50 & 50 & 45 & 45 \\
50 & 40 & 40 & 40 & 45 & 45 & 45 \\
35 & 35 & 45 & 35 & 35 & 35 & 40 \\
\hline
\end{tabular}

Média $=45 \pm 6.71$

Os valores abaixo foram obtidos nas lâminas dos canais radiculares, na região apical no comprimento de trabalho, posteriormente ao seu preparo auxiliado pelos diferentes métodos de irrigação, avaliando à presença de débris (detritos) e a área não tocada pelo instrumento.

\section{Grupo I (IRRIGAÇÃO CONVENCIONAL)}

Dente 1

\begin{tabular}{cccc}
\hline & Área total & Área com detritos & $\begin{array}{c}\text { Área náa tocada } \\
\text { pelo instrumento }\end{array}$ \\
\cline { 2 - 4 } & 4,38 & 0 & 4,26 \\
4,35 & 0 & 3,93 \\
& 4,33 & 0 & 4,03 \\
& 4,38 & 0 & 4,10 \\
& 4,38 & 0 & 4,04 \\
& 4,35 & 0 & 4,13 \\
& 4,48 & 0 & 4,21 \\
& 4,35 & 0 & 4,21 \\
média & 4,46 & 0 & 4,26 \\
& $\mathbf{4 , 3 8}$ & $\mathbf{0}$ & $\mathbf{4 , 1 7}$ \\
& $\mathbf{\%}$ & $\mathbf{0 \%}$ & $\mathbf{4 , 7 \%}$ (área efetiv) \\
\hline
\end{tabular}


Dente 2

\begin{tabular}{cccc}
\hline & Área total & Área com detritos & $\begin{array}{c}\text { Área náa tocada } \\
\text { pelo instrumento }\end{array}$ \\
\cline { 2 - 4 } & 2,28 & 0,54 & 1,55 \\
2,26 & 0,55 & 0,44 \\
2,34 & 0,58 & 0,60 \\
2,33 & 0,54 & 0,55 \\
2,29 & 0,48 & 0,49 \\
2,34 & 0,59 & 0,59 \\
2,33 & 0,45 & 0,48 \\
& 2,41 & 0,53 & 0,54 \\
& 2,28 & 0,51 & 1,82 \\
& 2,10 & 0,39 & 1,71 \\
& $\mathbf{2 , 3 1}$ & $\mathbf{0 , 5 3}$ & $\mathbf{0 , 5 7}$ \\
& $\mathbf{\%}$ & $\mathbf{2 2 , 9 4 \%}$ & $\mathbf{7 5 , 3 2 \%}$ (área efetiv) \\
\hline
\end{tabular}

Dente 3

\begin{tabular}{cccc}
\hline & Área total & Área com detritos & $\begin{array}{c}\text { Área não tocada pelo } \\
\text { instrumento }\end{array}$ \\
\cline { 2 - 4 } & 3,76 & 0,67 & 2,0 \\
3,83 & 0,35 & 2,8 \\
3,88 & 0,39 & 2,13 \\
3,56 & 0,34 & 1,92 \\
3,84 & 0,44 & 1,92 \\
3,63 & 0,36 & 2,26 \\
& 3,82 & 0,56 & 1,89 \\
& 3,78 & 0,33 & 1,83 \\
& 3,81 & 0,65 & 1,90 \\
& 3,79 & 0,46 & 1,69 \\
& $\mathbf{3 , 8 0}$ & $\mathbf{0 , 4 1}$ & $\mathbf{1 , 9 2}$ \\
& $\mathbf{\%}$ & $\mathbf{1 0 , 7 8 \%}$ & $\mathbf{4 9 , 4 7 \%}$ (área efetiv) \\
\hline
\end{tabular}

Dente 5

\begin{tabular}{cccc}
\hline & Área total & Área com detritos & $\begin{array}{c}\text { Área não tocada } \\
\text { pelo instrumento }\end{array}$ \\
\cline { 2 - 4 } & 4,53 & 0,14 & 4,36 \\
5,34 & 0,12 & 4,35 \\
5,57 & 0,13 & 4,79 \\
6,05 & 0,14 & 4,14 \\
5,39 & 0,02 & 4,45 \\
5,43 & 0,1 & 4,63 \\
& 6,11 & 0 & 4,03 \\
& 4,99 & 0,04 & 4,35 \\
& 5,05 & 0,03 & 4,57 \\
& 5,12 & 0,04 & 4,28 \\
& $\mathbf{5 , 3 6}$ & $\mathbf{0 , 0 7}$ & $\mathbf{4 , 3 5}$ \\
média & $\mathbf{\%}$ & $\mathbf{1 , 3 0 \%}$ & $\mathbf{1 8 , 8 4 \%}$ (área efetiv) \\
\hline
\end{tabular}


Dente 6

\begin{tabular}{cccc}
\hline & Área total & Área com detritos & $\begin{array}{c}\text { Área não tocada } \\
\text { pelo instrumento }\end{array}$ \\
\cline { 2 - 4 } & 9,36 & 0 & 1,05 \\
& 7,64 & 0,06 & 0,43 \\
9,54 & 0,16 & 0,59 \\
9,76 & 0,08 & 0,59 \\
8,64 & 0,23 & 1,44 \\
& 8,84 & 0,14 & 1,31 \\
& 8,48 & 0,03 & 0,86 \\
& 7,33 & 0 & 1,26 \\
média & 8,43 & 0,18 & 0,77 \\
& 9,36 & 0 & $\mathbf{0 , 7 7}$ \\
& $\mathbf{8 , 7 4}$ & $\mathbf{0 , 0 7}$ & $\mathbf{9 1 , 1 8 \%}$ (área efetiv) \\
\hline
\end{tabular}

Dente 7

\begin{tabular}{cccc}
\hline & Área total & Área com detritos & $\begin{array}{c}\text { Área não tocada } \\
\text { pelo instrumento }\end{array}$ \\
\cline { 2 - 4 } & 3,29 & 0,07 & 3,16 \\
3,74 & 0,04 & 3,61 \\
2,71 & 0,06 & 2,59 \\
3,89 & 0,10 & 3,44 \\
3,96 & 0,08 & 3,69 \\
3,88 & 0,14 & 2,62 \\
& 3,15 & 0,11 & 2,83 \\
& 3,86 & 0,12 & 2,65 \\
& 3,83 & 0,08 & 2,37 \\
& 3,19 & 0,15 & 2,67 \\
& $\mathbf{3 , 7 8}$ & $\mathbf{0 , 1 5}$ & $\mathbf{2 9 9}$ \\
& $\mathbf{\%}$ & $\mathbf{3 , 9 6 \%}$ & $\mathbf{2 0 , 8 9 \%}$ (área efetiv) \\
\hline
\end{tabular}

Dente 8

\begin{tabular}{cccc}
\hline & Área total & Área com detritos & $\begin{array}{c}\text { Área não tocada pelo } \\
\text { instrumento }\end{array}$ \\
\cline { 2 - 4 } & 2,46 & 0,20 & 1,45 \\
2,01 & 0,09 & 1,37 \\
1,92 & 0,05 & 1,36 \\
2,39 & 0,16 & 1,28 \\
2,47 & 0,07 & 0,46 \\
2,09 & 0,05 & 0,70 \\
2,34 & 0,07 & 0,97 \\
& 2,22 & 0,07 & 0,81 \\
& 2,46 & 0,07 & 0,79 \\
& 2,22 & 0,06 & 0,95 \\
média & $\mathbf{2 , 2 8}$ & $\mathbf{0 , 0 6}$ & $\mathbf{0 , 9 5}$ \\
& $\mathbf{\%}$ & $\mathbf{2 , 6 3 \%}$ & $\mathbf{5 8 , 3 3 \%}$ (área efetiv) \\
\hline
\end{tabular}


Dente 9

\begin{tabular}{cccc}
\hline & Área total & Área com detritos & $\begin{array}{c}\text { Área não tocada pelo } \\
\text { instrumento }\end{array}$ \\
\cline { 2 - 4 } & 3,71 & 0,39 & 1,25 \\
3,38 & 0,46 & 1,24 \\
3,53 & 0,36 & 1,33 \\
3,64 & 0,33 & 1,33 \\
2,78 & 0,24 & 1,02 \\
3,33 & 0,26 & 1,20 \\
& 3,69 & 0,38 & 1,64 \\
& 3,67 & 0,68 & 1,28 \\
& 3,75 & 0,50 & 1,30 \\
& 3,58 & 0,53 & 1,16 \\
& $\mathbf{3 , 6 1}$ & $\mathbf{0 , 5 3}$ & $\mathbf{1 , 1 6}$ \\
& $\mathbf{\%}$ & $\mathbf{1 4 , 6 8 \%}$ & $\mathbf{6 7 , 8 6 \%}$ (área efetiv) \\
\hline
\end{tabular}

Dente 10

\begin{tabular}{cccc}
\hline & Área total & Área com detritos & $\begin{array}{c}\text { Área não tocada } \\
\text { pelo instrumento }\end{array}$ \\
\cline { 2 - 4 } & 3,86 & 1,02 & 2,51 \\
& 3,91 & 1,74 & 2,67 \\
3,92 & 1,24 & 2,19 \\
4,08 & 1,27 & 2,30 \\
3,80 & 0,97 & 1,95 \\
& 1,97 & 0,23 & 1,14 \\
& 3,86 & 1,11 & 2,27 \\
& 3,63 & 1,21 & 2,02 \\
& $\mathbf{3 , 8 6}$ & $\mathbf{1 , 1 6}$ & $\mathbf{2 , 0 2}$ \\
& $\mathbf{\%}$ & $\mathbf{3 0 , 0 5 \%}$ & $\mathbf{4 7 , 6 6 \%} \%$ (área efetiv) \\
\hline
\end{tabular}

Dente 11

\begin{tabular}{cccc}
\hline & Área total & Área com detritos & $\begin{array}{c}\text { Área não tocada pelo } \\
\text { instrumento }\end{array}$ \\
\cline { 2 - 4 } & 3,46 & 0,42 & 1,81 \\
3,63 & 0,05 & 0,74 \\
3,59 & 0,49 & 1,74 \\
3,62 & 0,94 & 1,21 \\
3,71 & 0,67 & 2,06 \\
3,60 & 0,73 & 1,42 \\
& 3,36 & 0,38 & 0,91 \\
& 3,44 & 0 & 0,79 \\
& 3,41 & 0,43 & 1,52 \\
& 3,63 & 0,58 & 1,00 \\
& $\mathbf{3 , 5 9}$ & $\mathbf{0 , 4 6}$ & $\mathbf{1 , 3 1}$ \\
& $\mathbf{\%}$ & $\mathbf{1 2 , 8 1 \%}$ & $\mathbf{6 3 , 5 0 \%}$ (área efetiv) \\
\hline
\end{tabular}


Dente 13

\begin{tabular}{cccc}
\hline & Área total & Área com detritos & $\begin{array}{c}\text { Área não tocada } \\
\text { pelo instrumento }\end{array}$ \\
\cline { 2 - 4 } & 3,98 & 1,43 & 3,02 \\
3,74 & 1,35 & 2,28 \\
3,85 & 1,38 & 2,40 \\
3,81 & 1,31 & 2,04 \\
3,80 & 1,49 & 2,86 \\
3,96 & 1,33 & 2,77 \\
& 3,80 & 0,97 & 2,75 \\
& 4,05 & 1,04 & 2,55 \\
& 3,64 & 0,89 & 2,15 \\
& 3,73 & 0,85 & 2,27 \\
& $\mathbf{3 , 8 0}$ & $\mathbf{0 , 8 5}$ & $\mathbf{2 , 2 7}$ \\
& & $\mathbf{2 2 , 3 6 \%}$ & $\mathbf{4 0 , 2 6} \%$ (área efetiv) \\
\hline
\end{tabular}

Dente 14

Dente 15

\begin{tabular}{ccc} 
Área total & Área com detritos & $\begin{array}{c}\text { Área não tocada } \\
\text { pelo instrumento }\end{array}$ \\
\hline 3,30 & 0,05 & 0,64 \\
3,10 & 0,11 & 1,09 \\
2,90 & 0,24 & 0,92 \\
2,79 & 0,21 & 0,65 \\
2,56 & 0,10 & 0,34 \\
2,70 & 0,20 & 0,47 \\
3,11 & 0,40 & 0,62 \\
2,94 & 0,20 & 0,71 \\
3,09 & 0,30 & 0,69 \\
2,90 & 0,21 & 0,66 \\
$\mathbf{2 , 9 2}$ & $\mathbf{0 , 2 1}$ & $\mathbf{0 , 6 6}$ \\
& $\mathbf{7 , 1 9 \%}$ & $\mathbf{7 7 , 3 9} \%$ (área efetiv) \\
\hline
\end{tabular}

\begin{tabular}{cccc}
\hline & Área total & Área com detritos & $\begin{array}{c}\text { Área não tocada } \\
\text { pelo instrumento }\end{array}$ \\
\cline { 2 - 4 } & 5,90 & 0,21 & 0,72 \\
& 5,84 & 0,06 & 0,33 \\
& 5,85 & 0,20 & 0,20 \\
& 6,15 & 0,14 & 0,46 \\
& 5,89 & 0,13 & 0,62 \\
média & 5,69 & 0,05 & 0,24 \\
& 5,95 & 0,17 & 0,37 \\
& $\mathbf{5 , 8 9}$ & $\mathbf{0 , 1 4}$ & $\mathbf{0 , 3 7}$ \\
& & $\mathbf{2 , 3 7 \%}$ & $\mathbf{9 3 , 7 1} \%$ (área efetiv) \\
\hline
\end{tabular}


Dente 16

\begin{tabular}{cccc}
\hline & Área total & Área com detritos & $\begin{array}{c}\text { Área não tocada } \\
\text { pelo instrumento }\end{array}$ \\
\cline { 2 - 4 } & 2,60 & 0,09 & 1,22 \\
& 1,94 & 0,03 & 1,62 \\
& 3,00 & 0,31 & 1,81 \\
& 2,14 & 0,07 & 1,82 \\
& 2,99 & 0,20 & 2,20 \\
& 3,44 & 0,19 & 2,41 \\
média & 3,43 & 0,22 & 2,80 \\
& $\mathbf{2 , 9 9}$ & $\mathbf{0 , 1 9}$ & $\mathbf{2 , 4 1}$ \\
& & $\mathbf{6 , 3 5 \%}$ & $\mathbf{1 9 , 3 9 \%} \%$ (área efetiv) \\
\hline
\end{tabular}

Dente 17

\begin{tabular}{ccc} 
Área total & Área com detritos & $\begin{array}{c}\text { Área não tocada } \\
\text { pelo instrumento }\end{array}$ \\
\hline 3,16 & 0,53 & 1,08 \\
2,97 & 0,32 & 0,99 \\
3,26 & 0,42 & 0,99 \\
3,20 & 0,50 & 1,02 \\
3,32 & 0,45 & 1,11 \\
3,31 & 0,55 & 1,19 \\
3,44 & 0,68 & 2,76 \\
3,61 & 0,56 & 2,41 \\
3,51 & 0,46 & 2,87 \\
3,57 & 0,54 & 2,59 \\
$\mathbf{3 , 3 1}$ & $\mathbf{0 , 5 1}$ & $\mathbf{1 , 1 5}$ \\
& $\mathbf{1 5 , 4 0 \%}$ & $\mathbf{6 5 , 2 5} \%$ (área efetiv) \\
\hline
\end{tabular}

Dente 18

\begin{tabular}{ccc} 
Área total & Área com detritos & $\begin{array}{c}\text { Área não tocada } \\
\text { pelo instrumento }\end{array}$ \\
\hline 3,51 & 1,20 & 0,05 \\
3,35 & 1,11 & 0,13 \\
3,35 & 1,22 & 0,09 \\
3,33 & 1,29 & 0,10 \\
3,18 & 1,26 & 0,35 \\
3,46 & 1,38 & 0,12 \\
3,39 & 1,40 & 0,15 \\
3,48 & 1,18 & 0,11 \\
$\mathbf{3 , 3 7}$ & $\mathbf{1 , 2 4}$ & $\mathbf{0 , 1 1}$ \\
& $\mathbf{3 6 , 7 9 \%}$ & $\mathbf{9 6 , 7 3} \%$ (área efetiv) \\
\hline
\end{tabular}


Dente 19

\begin{tabular}{cccc}
\hline & Área total & Área com detritos & $\begin{array}{c}\text { Área não tocada } \\
\text { pelo instrumento }\end{array}$ \\
\cline { 2 - 4 } & 4,42 & 2,01 & 3,17 \\
4,56 & 2,34 & 3,23 \\
4,31 & 2,12 & 3,38 \\
4,38 & 2,07 & 3,39 \\
4,91 & 2,05 & 3,68 \\
& 3,67 & 1,46 & 2,55 \\
& 3,70 & 1,53 & 2,59 \\
& 4,05 & 1,83 & 2,96 \\
& 4,14 & 1,91 & 2,82 \\
& 3,99 & 1,92 & 2,85 \\
& $\mathbf{4 , 2 2}$ & $\mathbf{1 , 9 6}$ & $\mathbf{3 , 0 6}$ \\
& & $\mathbf{4 6 , 4 4 \%}$ & $\mathbf{2 7 , 4 8} \%$ (área efetiv) \\
\hline
\end{tabular}

Dente 20

\begin{tabular}{cccc}
\hline & Área total & Área com detritos & $\begin{array}{c}\text { Área não tocada } \\
\text { pelo instrumento }\end{array}$ \\
\cline { 2 - 4 } & 3,98 & 0,11 & 0,92 \\
3,17 & 0,08 & 0,72 \\
& 2,63 & 0,10 & 0,36 \\
& 3,21 & 0,05 & 0,71 \\
& 3,29 & 0,50 & 0,76 \\
& 3,33 & 0,46 & 0,46 \\
& 3,18 & 0,43 & 0,65 \\
média & 3,25 & 0,15 & 0,31 \\
& $\mathbf{3 , 2 3}$ & $\mathbf{0 , 1 3}$ & $\mathbf{0 , 6 8}$ \\
& & $\mathbf{4 , 0 2 \%}$ & $\mathbf{7 8 , 9 4} \%$ (área efetiv) \\
\hline
\end{tabular}

Dente 21

\begin{tabular}{cccc}
\hline & Área total & Área com detritos & $\begin{array}{c}\text { Área não tocada } \\
\text { pelo instrumento }\end{array}$ \\
\cline { 2 - 4 } & 4,58 & 0 & 0,32 \\
& 4,51 & 0 & 0,67 \\
& 4,54 & 0 & 2,19 \\
& 4,64 & 0 & 0,46 \\
& 4,88 & 0 & 0,28 \\
média & 4,72 & 0 & 0,31 \\
& $\mathbf{4 , 5 8}$ & 0 & 0,22 \\
& & $\mathbf{0}$ & $\mathbf{0 , 3 2}$ \\
& & $\mathbf{0 \%}$ & $\mathbf{9 3 , 0 1} \%$ (área efetiv) \\
\hline
\end{tabular}


Grupo II (IRRIGAÇÃO HIDRODINÂMICA)

Dente 1

\begin{tabular}{cccc}
\hline & Área total & Área com detritos & $\begin{array}{c}\text { Área não tocada } \\
\text { pelo instrumento }\end{array}$ \\
\cline { 2 - 4 } & 4,11 & 0,55 & 1,84 \\
4,43 & 0,70 & 1,76 \\
4,41 & 0,80 & 1,89 \\
4,51 & 1,04 & 2,14 \\
4,58 & 1,06 & 1,74 \\
& 4,04 & 0,67 & 1,62 \\
& 4,57 & 1,10 & 0,87 \\
& 4,11 & 0,66 & 1,34 \\
& 4,20 & 0,40 & 1,13 \\
média & 4,22 & 0,31 & $\mathbf{1 , 7 5}$ \\
& $\mathbf{4 , 3 1}$ & $\mathbf{0 , 6 8}$ & $\mathbf{1 5 , 7 7 \%}$ \\
& & & $\mathbf{5 9 , 3 9} \%$ (área efetiv) \\
\hline
\end{tabular}

Dente 2

\begin{tabular}{ccc} 
Área total & Área com detritos & $\begin{array}{c}\text { Área não tocada } \\
\text { pelo instrumento }\end{array}$ \\
\hline 3,64 & 0,53 & 1,61 \\
3,95 & 0,46 & 1,62 \\
3,89 & 0,54 & 1,76 \\
3,94 & 0,73 & 2,01 \\
3,93 & 0,62 & 2,09 \\
4,01 & 0,68 & 1,44 \\
4,38 & 0,77 & 1,61 \\
3,78 & 0,61 & 1,88 \\
3,75 & 0,58 & 1,59 \\
3,68 & 0,57 & 1,01 \\
$\mathbf{3 , 9 1}$ & $\mathbf{0 , 5 9}$ & $\mathbf{1 , 6 1}$ \\
& $\mathbf{1 5 , 0 8 \%}$ & $\mathbf{5 8 , 8 2} \%$ (área efetiv) \\
\hline
\end{tabular}

Dente 5

\begin{tabular}{cccc}
\hline & Área total & Área com detritos & $\begin{array}{c}\text { Área não tocada } \\
\text { pelo instrumento }\end{array}$ \\
\cline { 2 - 4 } & 1,72 & 0 & 0,65 \\
1,68 & 0,08 & 0,51 \\
& 1,70 & 0 & 0,55 \\
& 1,58 & 0,06 & 0,36 \\
& 1,66 & 0,06 & 0,35 \\
& 1,58 & 0 & 0,33 \\
& 1,63 & 0,04 & 0,49 \\
& 1,60 & 0,08 & 0,69 \\
média & 1,40 & 0,04 & 0,27 \\
& $\mathbf{1 , 6 1}$ & 0,05 & 0,37 \\
& & $\mathbf{0 , 0 4}$ & $\mathbf{0 , 4 3}$ \\
& $\mathbf{2 , 4 8 \%}$ & $\mathbf{7 3 , 2 9} \%$ (área efetiv) \\
\hline
\end{tabular}


Dente 6

\begin{tabular}{cccc}
\hline & Área total & Área com detritos & $\begin{array}{c}\text { Área não tocada } \\
\text { pelo instrumento }\end{array}$ \\
\cline { 2 - 4 } & 6,92 & 0,13 & 0,38 \\
7,00 & 0 & 0,47 \\
7,02 & 0 & 0,71 \\
6,89 & 0,09 & 0,40 \\
6,76 & 0,24 & 0,99 \\
6,75 & 0 & 0,68 \\
& 6,72 & 0,21 & 0,68 \\
& 6,87 & 0,06 & 0,89 \\
média & 6,99 & 0,15 & 2,63 \\
& 6,97 & 0,12 & 1,29 \\
& $\mathbf{6 , 9 0}$ & $\mathbf{0 , 1 0}$ & $\mathbf{0 , 6 9}$ \\
& & $\mathbf{1 , 4 4 \%}$ & $\mathbf{9 0} \%$ (área efetiva) \\
\hline
\end{tabular}

Dente 7

\begin{tabular}{cccc}
\hline & Área total & Área com detritos & $\begin{array}{c}\text { Área não tocada } \\
\text { pelo instrumento }\end{array}$ \\
\cline { 2 - 4 } & 11,76 & 4,70 & 11,36 \\
12,06 & 4,55 & 11,73 \\
11,53 & 3,99 & 11,16 \\
11,96 & 5,29 & 11,51 \\
12,34 & 3,11 & 11,98 \\
12,52 & 3,31 & 11,87 \\
11,99 & 3,99 & 11,98 \\
& 12,56 & 3,94 & 12,12 \\
& 11,59 & 5,12 & 11,08 \\
& 11,94 & 4,97 & 11,61 \\
média & $\mathbf{1 1 , 9 7}$ & $\mathbf{4 , 2 7}$ & $\mathbf{1 1 , 6 7}$ \\
& & $\mathbf{3 5 , 6 7 \%}$ & $\mathbf{2 , 5 0} \%$ (área efetiva) \\
\hline
\end{tabular}

Dente 8

\begin{tabular}{cccc} 
& Área total & Área com detritos & $\begin{array}{c}\text { Área não tocada } \\
\text { pelo instrumento }\end{array}$ \\
\cline { 2 - 4 } & 4,57 & 0,08 & 1,09 \\
& 4,63 & 0,47 & 0,56 \\
4,69 & 0,43 & 0,57 \\
4,59 & 0,22 & 0,47 \\
4,72 & 0 & 0,32 \\
& 4,90 & 0 & 0,24 \\
& 4,57 & 0,04 & 0,63 \\
& 4,44 & 0 & 0,53 \\
média & 4,87 & 0,15 & 0,47 \\
& 4,64 & 0,65 & 0,49 \\
& $\mathbf{4 , 6 3}$ & $\mathbf{0 , 1 1}$ & $\mathbf{0 , 5 1}$ \\
& & $\mathbf{2 , 3 7 \%}$ & $\mathbf{8 8 , 9 8} \%$ (área efetiv) \\
\hline
\end{tabular}


Dente 9

\begin{tabular}{cccc}
\hline & Área total & Área com detritos & $\begin{array}{c}\text { Área não tocada } \\
\text { pelo instrumento }\end{array}$ \\
\cline { 2 - 4 } & 3,95 & 0,13 & 0 \\
4,15 & 0,04 & 0 \\
4,32 & 0 & 0 \\
4,15 & 0 & 0,59 \\
4,01 & 0,11 & 0,48 \\
4,26 & 0 & 0 \\
4,25 & 0 & 0 \\
4,08 & 0 & 0 \\
4,25 & 0 & 0 \\
& 4,18 & $\mathbf{0}$ & $\mathbf{0}$ \\
& $\mathbf{4 , 1 6}$ & $\mathbf{0 \%}$ & $\mathbf{1 0 0 \%}$ (área efetiv) \\
\hline
\end{tabular}

Dente 10

\begin{tabular}{cccc}
\hline & Área total & Área com detritos & $\begin{array}{c}\text { Área não tocada } \\
\text { pelo instrumento }\end{array}$ \\
\cline { 2 - 4 } & 2,83 & 0 & 2,04 \\
2,78 & 0 & 1,96 \\
2,68 & 0 & 1,95 \\
2,80 & 0 & 2,01 \\
2,93 & 0 & 2,11 \\
3,00 & 0 & 2,34 \\
& 2,51 & 0 & 1,78 \\
& 2,66 & 0 & 2,17 \\
& 2,58 & 0 & 1,91 \\
& 2,77 & 0 & 2,04 \\
& $\mathbf{2 , 7 7}$ & $\mathbf{0}$ & $\mathbf{2 , 0 4}$ \\
& & $\mathbf{0 \%}$ & $\mathbf{2 6 , 3 5} \%$ \%(área efetiv) \\
\hline
\end{tabular}

Dente 11

\begin{tabular}{cccc} 
& Área total & Área com detritos & $\begin{array}{c}\text { Área ño tocada } \\
\text { pelo instrumento }\end{array}$ \\
\cline { 2 - 4 } & 5,52 & 0,50 & 0,63 \\
5,47 & 0,10 & 0,21 \\
5,37 & 0,26 & 0,22 \\
5,59 & 0,31 & 0,19 \\
& 5,49 & 0,40 & 0,23 \\
& 5,68 & 0,14 & 0,20 \\
& 5,59 & 0,64 & 0,30 \\
& 5,66 & 0,51 & 0,48 \\
média & 5,35 & 0,08 & 0,30 \\
& 5,34 & 0,30 & 0,39 \\
& $\mathbf{5 , 5 0}$ & $\mathbf{0 , 3 0}$ & $\mathbf{0 , 2 6}$ \\
& & $\mathbf{5 , 4 5 \%}$ & $\mathbf{9 5 , 2 7} \%$ (área efetiv) \\
\hline
\end{tabular}


Dente 12

\begin{tabular}{cccc}
\hline Área total & Área com detritos & $\begin{array}{c}\text { Área não tocada } \\
\text { pelo instrumento }\end{array}$ \\
\cline { 2 - 4 } & 4,17 & 0 & 1,77 \\
4,18 & 0 & 1,83 \\
4,21 & 0 & 0,37 \\
4,27 & 0,09 & 0,71 \\
4,22 & 0 & 1,07 \\
4,15 & 0 & 1,64 \\
4,34 & 0 & 1,86 \\
& 4,21 & 0 & 1,22 \\
média & 3,99 & 0 & 0,94 \\
& 4,20 & 0 & 0,87 \\
& $\mathbf{4 , 2 0}$ & $\mathbf{0}$ & $\mathbf{1 , 1 4}$ \\
& & $\mathbf{0 \%}$ & $\mathbf{7 2 , 8 5} \%$ (área efetiv) \\
\hline
\end{tabular}

Dente 13

Dente 15

\begin{tabular}{ccc} 
Área total & Área com detritos & $\begin{array}{c}\text { Área não tocada } \\
\text { pelo instrumento }\end{array}$ \\
\hline 2,21 & 0 & 1,39 \\
2,28 & 0 & 1,69 \\
2,23 & 0 & 1,21 \\
2,26 & 0 & 1,30 \\
2.09 & 0 & 0,94 \\
2,15 & 0 & 1,19 \\
2,15 & 0 & 0,94 \\
2,27 & 0 & $-1,08$ \\
2,25 & 0 & 1,21 \\
2,28 & 0 & 1,28 \\
$\mathbf{2 , 2 5}$ & $\mathbf{0}$ & $\mathbf{1 , 2 8}$ \\
& $\mathbf{0 \%}$ & $\mathbf{4 3 , 1 1} \%$ (área efetiv) \\
\hline
\end{tabular}

\begin{tabular}{cccc} 
& Área total & Área com detritos & $\begin{array}{c}\text { Área não tocada } \\
\text { pelo instrumento }\end{array}$ \\
\cline { 2 - 4 } & 3,17 & 0,71 & 0,42 \\
3,32 & 0,72 & 1,10 \\
3,37 & 0,75 & 0,34 \\
3,18 & 0,93 & 0,72 \\
3,20 & 0,78 & 0,29 \\
& 3,08 & 0,99 & 1,09 \\
& 3,13 & 0,75 & 0,40 \\
& 3,16 & 0,73 & 0,81 \\
& 3,12 & 0,74 & 0,43 \\
média & 3,35 & 0,72 & 1,26 \\
& $\mathbf{3 , 1 7}$ & $\mathbf{0 , 7 4}$ & $\mathbf{0 , 5 7}$ \\
& & $\mathbf{2 3 , 3 4 \%}$ & $\mathbf{8 2 , 0 1} \%$ (área efetiv) \\
\hline
\end{tabular}


Dente 16

\begin{tabular}{cccc}
\hline & Área total & Área com detritos & $\begin{array}{c}\text { Área não tocada } \\
\text { pelo instrumento }\end{array}$ \\
\cline { 2 - 4 } & 4,41 & 0,81 & 2,73 \\
4,18 & 0,82 & 2,73 \\
4,49 & 0,99 & 2,71 \\
4,14 & 0,83 & 2,48 \\
4,58 & 0,92 & 3,00 \\
4,86 & 1,01 & 2,62 \\
4,13 & 1,12 & 2,03 \\
& 4,26 & 0,08 & 2,27 \\
& 4,01 & 0,93 & 2,21 \\
& 4,25 & 0,86 & 2,15 \\
& $\mathbf{4 , 2 5}$ & $\mathbf{0 , 9 2}$ & $\mathbf{2 , 5 5 \%}$ \\
& & $\mathbf{4 0} \%$ \%(área efetiv) \\
\hline
\end{tabular}

Dente 17

\begin{tabular}{cccc}
\hline & Área total & Área com detritos & $\begin{array}{c}\text { Área não tocada } \\
\text { pelo instrumento }\end{array}$ \\
\cline { 2 - 4 } & 5,15 & 0,79 & 2,17 \\
5,20 & 1,85 & 2,17 \\
5,26 & 1,89 & 1,96 \\
5,99 & 1,83 & 2,05 \\
5,41 & 1,71 & 2,00 \\
5,03 & 1,66 & 1,59 \\
4,98 & 1,76 & 1,54 \\
& 4,92 & 1,79 & 1,58 \\
& 4,87 & 1,72 & 1,59 \\
& 4,95 & 1,69 & 1,66 \\
& $\mathbf{5 , 0 9}$ & $\mathbf{1 , 7 4}$ & $\mathbf{1 , 8 1}$ \\
& & $\mathbf{3 4 , 1 8 \%}$ & $\mathbf{6 4 , 4 4} \%$ \%(área efetiv) \\
\hline
\end{tabular}

Dente 18

\begin{tabular}{cccc}
\hline & Área total & Área com detritos & $\begin{array}{c}\text { Área não tocada } \\
\text { pelo instrumento }\end{array}$ \\
\cline { 2 - 4 } & 6,14 & 0,11 & 0,39 \\
6,11 & 0,11 & 0,60 \\
6,30 & 0,10 & 0,51 \\
5,93 & 0,07 & 0,48 \\
6,69 & 0,09 & 0,51 \\
& 6,23 & 0,08 & 0,34 \\
& 6,24 & 0,10 & 0,34 \\
& 6,23 & 0,10 & 0,43 \\
& 6,16 & 0,14 & 0,42 \\
& 6,26 & 0,06 & 0,44 \\
& $\mathbf{6 , 2 3}$ & $\mathbf{0 , 1 0}$ & $\mathbf{0 , 4 3}$ \\
& & $\mathbf{1 , 6 0 \%}$ & $\mathbf{9 3 , 0 9 \%} \%$ área efetiv) \\
\hline
\end{tabular}


Dente 19

\begin{tabular}{cccc}
\hline & Área total & Área com detritos & $\begin{array}{c}\text { Área não tocada } \\
\text { pelo instrumento }\end{array}$ \\
\cline { 2 - 4 } & 4,23 & 1,62 & 2,13 \\
3,19 & 1,54 & 2,51 \\
3,89 & 1,81 & 3,20 \\
3,72 & 1,83 & 3,56 \\
3,91 & 1,79 & 3,24 \\
3,29 & 1,79 & 3,12 \\
& 3,59 & 2,00 & 3,44 \\
& 3,82 & 2,03 & 3,74 \\
& 3,97 & 1,72 & 3,12 \\
& 3,97 & 2,03 & 3,70 \\
& $\mathbf{3 , 8 5}$ & $\mathbf{1 , 8 0}$ & $\mathbf{3 , 2 2}$ \\
& & $\mathbf{4 6 , 7 5 \%}$ & $\mathbf{1 6 , 3 6} \%$ \% (área efetiv) \\
\hline
\end{tabular}

Dente 20

Dente 21

\begin{tabular}{ccc} 
Área total & Área com detritos & $\begin{array}{c}\text { Área não tocada } \\
\text { pelo instrumento }\end{array}$ \\
\hline 3,70 & 0 & 0,05 \\
3,67 & 0 & 0,07 \\
3,49 & 0 & 0,16 \\
3,59 & 0 & 0,07 \\
3,29 & 0 & 0,11 \\
3,60 & 0 & 0,09 \\
3,83 & 0 & 0,12 \\
3,99 & 0 & 0,05 \\
3,36 & 0 & 0,09 \\
3,60 & 0 & 0,26 \\
$\mathbf{3 , 6 0}$ & $\mathbf{0}$ & $\mathbf{0 , 0 9}$ \\
& $\mathbf{0 \%}$ & $\mathbf{9 7 , 5 \%}$ (área efetiv) \\
\hline
\end{tabular}

\begin{tabular}{cccc} 
& Área total & Área com detritos & $\begin{array}{c}\text { Área não tocada } \\
\text { pelo instrumento }\end{array}$ \\
\cline { 2 - 4 } & 4,71 & 0,05 & 0,03 \\
4,56 & 0,16 & 0,17 \\
4,70 & 0 & 0,51 \\
4,68 & 0,16 & 0,46 \\
4,64 & 0,08 & 0,24 \\
& 4,82 & 0,17 & 0,52 \\
& 4,79 & 0,07 & 0,35 \\
média & 4,57 & 0,07 & 0,16 \\
& 4,80 & 0,19 & 0,69 \\
& 4,68 & 0,11 & 0,25 \\
& $\mathbf{4 , 6 9}$ & $\mathbf{0 , 0 9}$ & $\mathbf{0 , 3 0}$ \\
& & $\mathbf{2 , 0 1 \%}$ & $\mathbf{9 3 , 6 0} \%$ (área efetiv) \\
\hline
\end{tabular}




\section{Grupo I (CONVENCIONAL)}

Porcentagem de débris encontrado nos canais radiculares na área apical no CT com 3, 4 e 5 instrumentos acima do instrumento apical inicial (IAI).

\begin{tabular}{c|ccccccc}
\hline $\begin{array}{l}\text { Instrumentos } \\
\text { acima do IAI }\end{array}$ & \multicolumn{7}{|c}{ Porcentagem de débris (\%) } \\
\hline 3 & 50 & 7 & 4 & 28 & 0 & 0 & 0 \\
4 & 8 & 16 & 4 & 12 & 0 & 4 & 21 \\
5 & 2 & 40 & 19 & - & 15 & - & 12 \\
\hline
\end{tabular}

\section{Grupo II (HIDRODINÂMICA)}

Porcentagem de débris encontrado nos canais radiculares na área apical no CT com 3, 4 e 5 instrumentos acima do instrumento inicial apical (IAI).

\begin{tabular}{c|ccccccc}
\hline $\begin{array}{l}\text { Instrumentos } \\
\text { acima do IAI }\end{array}$ & \multicolumn{7}{|c}{ Porcentagem de débris (\%) } \\
\hline 3 & 44 & 10 & 25 & 0 & 8 & 4 & - \\
4 & 3 & 17 & - & 10 & 9 & 1 & 6 \\
5 & 11 & 24 & 0 & 20 & 46 & - & 10 \\
\hline
\end{tabular}



Anexo 
ANEXO A - TERMO de APROVAÇÃO DA PESQUISA PELO COMITÊ DE ÉTICA EM PESQUISA, DA FACULDADE DE ODONTOLOGIA DE RIBEIRÃO PRETO ${ }^{1}$

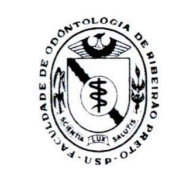

OF.CEP/219/FORP

\author{
UNIVERSIDADE DE SÃO PAULO \\ FACULDADE DE ODONTOLOGIA DE RIBEIRÃO PRETO \\ COMITÊ DE ÉTICA EM PESQUISA \\ Avenida do Café, $s / n^{\circ}$ - Telefone: (016) 3602-3963 \\ 14040-904 - Ribeirão Preto - SP - Brasil \\ Fax: (016) 3633-0999
}

Ribeirão Preto, 25 de maio de 2009

Prezado Senhor,

Ref.: Processo no 2009.1.500.58.5 CAAE n' 0039.0.138.000-09

A pedido da Profa. Dra. Cláudia Helena Lovato da Silva, Coordenadora do Comitê de Ética em Pesquisa, desta Faculdade, informamos que o referido Comitê em sua 98a Sessão, realizada em 21 de maio de 2009, aprovou o Projeto de Pesquisa: "Avaliação histológica da limpeza dos canais com achatamento radicular promovida por diferentes métodos de irrigação e análise tomográfica do diâmetro apical antes e após o preparo mecanizado".

$\mathrm{Na}$ oportunidade, lembramos da necessidade de entregar na Secretaria do Comitê, com o formulário preenchido pelo pesquisador responsável, o Relatório Final no dia 21 de maio de 2010.

Atenciosamente,

$$
\begin{gathered}
\text { Gaun puon } \\
\text { Glauce Della Rosa } \\
\text { Secretária do Comitê de Ética em Pesquisa }
\end{gathered}
$$

Ilmo. Sr.

PG. FÁBIO HEREDIA SEIXAS

Departamento de Odontologia Restauradora - FORP/USP

Secretária do Comitê de Ética em Pesquisa - Glauce Della Rosa - e-mail: glauce@forp.usp.br

\footnotetext{
${ }^{1}$ Ao longo do desenvolvimento da pesquisa e do direcionamento do seu objetivo, verificou-se a necessidade de modificação do título da pesquisa para o que consta na capa deste documento.
} 